\title{
Microwave-Assisted Syntheses of Bioactive Seven-Membered, Macro-Sized Heterocycles and Their Fused Derivatives
}

\author{
Mohsine Driowya ${ }^{1}$, Aziza Saber ${ }^{1}$, Hamid Marzag ${ }^{1}$, Luc Demange ${ }^{2,3, *}$, Khalid Bougrin ${ }^{1, *}$ \\ and Rachid Benhida ${ }^{2, *}$ \\ 1 Laboratoire de Chimie des Plantes et de Synthèse Organique et Bioorganique, URAC23, Faculté des Sciences, \\ Université Mohammed V, B.P. 1014 Rabat, Maroc; m.driowya@hotmail.com (M.D.); \\ aziza.saber@ymail.com (A.S.); marzaghamid@gmail.com (H.M.) \\ 2 Institut de Chimie de Nice, ICN UMR UNS CNRS 7272, Université Nice-Sophia Antipolis-Université Côte \\ d'Azur, Parc Valrose, 06108 Nice Cedex 2, France \\ 3 Département de Chimie, Université Paris Descartes, Sorbonne Paris Cité, UFR des Sciences \\ Pharmaceutiques, 4 avenue de l'Observatoire \& UFR Biomédicale des Saints Pères, 45 Rue des Saints Pères, \\ Paris Fr-75006, France \\ * Correspondence: luc.demange@unice.fr (L.D.); kbougrin@yahoo.fr (K.B.); rachid.benhida@unice.fr (R.B.); \\ Tel.: +212-5-37-775440 (K.B.); +33-4-9207-6143 (R.B.); Fax: +212-5-37-775440 (K.B.); +33-4-9207-6189 (R.B.)
}

Academic Editor: Philippe Belmont

Received: 17 June 2016; Accepted: 29 July 2016; Published: 9 August 2016

\begin{abstract}
This review describes the recent advances in the microwave-assisted synthesis of 7-membered and larger heterocyclic compounds. Several types of reaction for the cyclization step are discussed: Ring Closing Metathesis (RCM), Heck and Sonogashira reactions, Suzuki-Miyaura cross-coupling, dipolar cycloadditions, multi-component reactions (Ugi, Passerini), etc. Green syntheses and solvent-free procedures have been introduced whenever possible. The syntheses discussed herein have been selected to illustrate the huge potential of microwave in the synthesis of highly functionalized molecules with potential therapeutic applications, in high yields, enhanced reaction rates and increased chemoselectivity, compared to conventional methods. More than 100 references from the recent literature are listed in this review.
\end{abstract}

Keywords: microwave irradiation; bioactive molecules; dipolar cycloaddition; cyclocondensations; multicomponent reactions

\section{Introduction}

During the last decade, the continuous advances in microwave (MW) assisted syntheses have highlighted the huge potential of this technique for large-scale preparations of natural products and therapeutic agents. MW processes are highly compatible with the main reactions used in modern organic chemistry, such as ring closure metathesis (RCM), multi-component reaction (MCR), metal catalysed reaction (Heck, Ullmann, Sonogashira, Suzuki-Miyaura, etc), cyclocondensations, dipolar cycloadditions, etc. Moreover, MW technology has also been widely used for the development of eco-friendly and solvent-free syntheses of multi-functionalized molecules [1,2]. Indeed, more than 250 articles are devoted yearly to MW-assisted syntheses, an approach whose popularity is related not only to its low costs and its experimental simplicity but also to its compatibility with very mild conditions to perform sensitive reactions. Moreover, MW procedures are often associated with improved yields; enhanced chemoselectivity and purity compared to conventional procedures.

These benefits are mainly due to the physical characteristics of MW irradiation, which allow not only a better transmission of the energy to the reactants but also an homogeneous heating of the 
solution mixtures. In addition, the electric fields generated by the MWs cause oscillations and rotations of dipolar and ionic molecules, resulting in an additional local heating. This specific dielectric heating of polar reactants, so-called "specific microwave" or "non-thermal" effect, is often considered when MW irradiation leads to different products from the ones obtained through conventional heating at the same apparent temperature.

We recently reviewed the MW-assisted synthesis of 4-, 5- and 6-membered heterocycles [3,4]. The specific purpose of this review, mainly focused on results published during the last decade, is to highlight the MW applications to macrocyclic heterocycles. To this end, the first part of this review will be devoted to the synthesis of 7-membered heterocycles containing one, two or three heteroatoms (nitrogen, oxygen and sulphur). In the second part, selected syntheses of macrocycles (peptides, pseudo-peptides and calix-type molecules) will be discussed.

\section{Synthesis of Heterocyclic Compounds}

\subsection{Seven-Membered Heterocycles}

\subsubsection{Seven-Membered Heterocycles with One Heteroatom}

\section{Benzazepines and Fused Analogues}

The benzazepines form a class of seven-membered aza-heterocycles fused with an aromatic ring, which is divided into the three distinct isomeric forms (1-, 2- and 3-benzazepines), depending on the relative position of the nitrogen atom. A huge variety of bioactive molecules, including natural products extracted from plants or fungus, contain a benzazepine core, as illustrated by the scaffold of morphine (a 3-benzazepine). Numerous series of benzazepine derivatives have been marketed for their therapeutic use as anti-depressant, anti-hypertensive, anti-ischaemic, and their pharmacological properties have been recently reviewed by various researchers [5-9] (Figure 1).

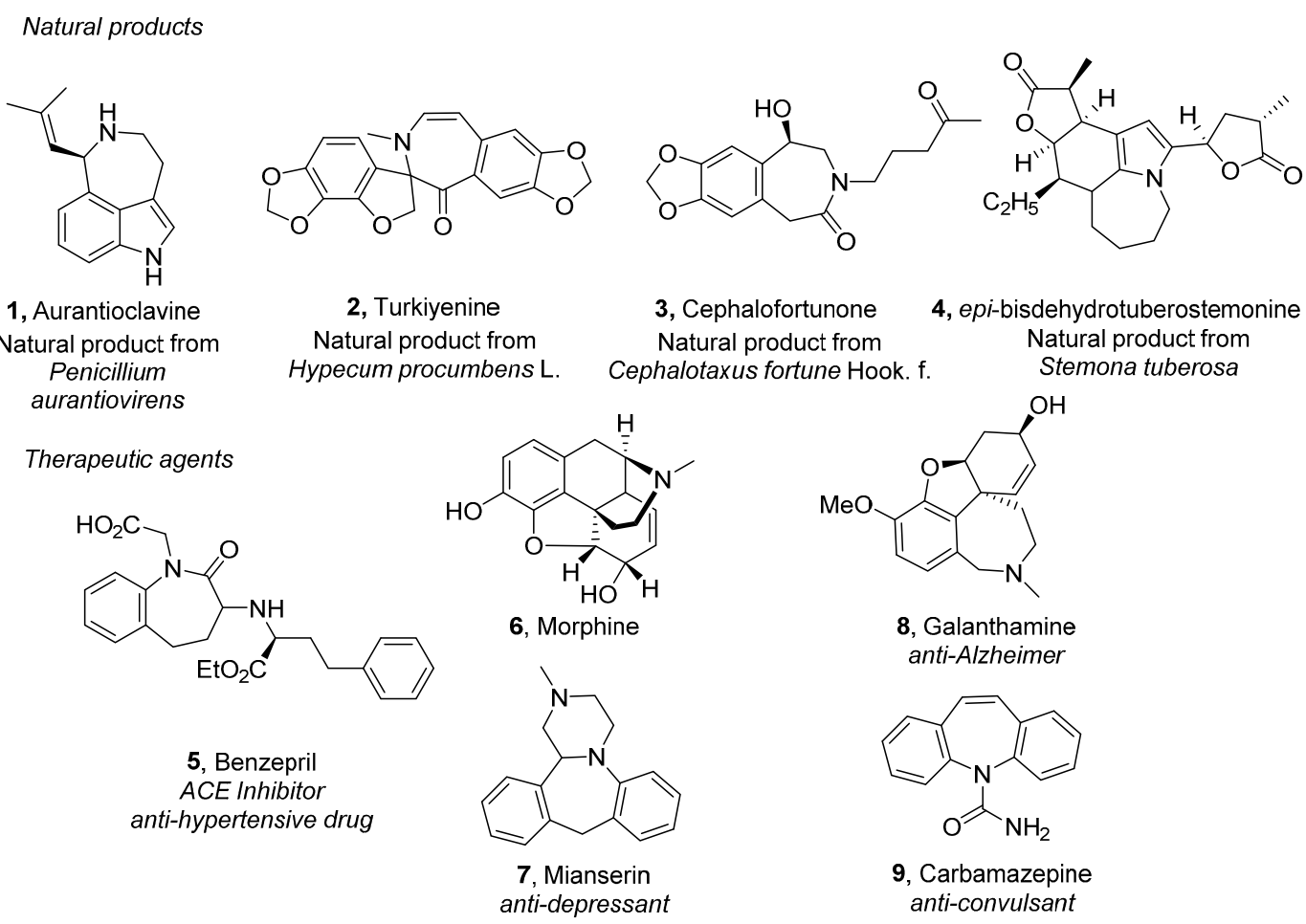

Figure 1. Representative examples of bioactive benzazepines. 


\section{2-Benzazepines and Their Derivatives}

Lamaty and co-workers have disclosed a palladium-catalysed Heck reaction under MW-heating in polyethyleneglycol (PEG) for the preparation of novel series of 2-benzazepines 14 starting from the protected $\beta$-aminoesters 12 (Scheme 1A) [10]. PEGs are low-toxicity solvents sharing common characteristics with ionic liquids, such as high polarity and high boiling points. Moreover, this synthesis is among the first reported procedures using PEGs in a MW-assisted reaction.

A

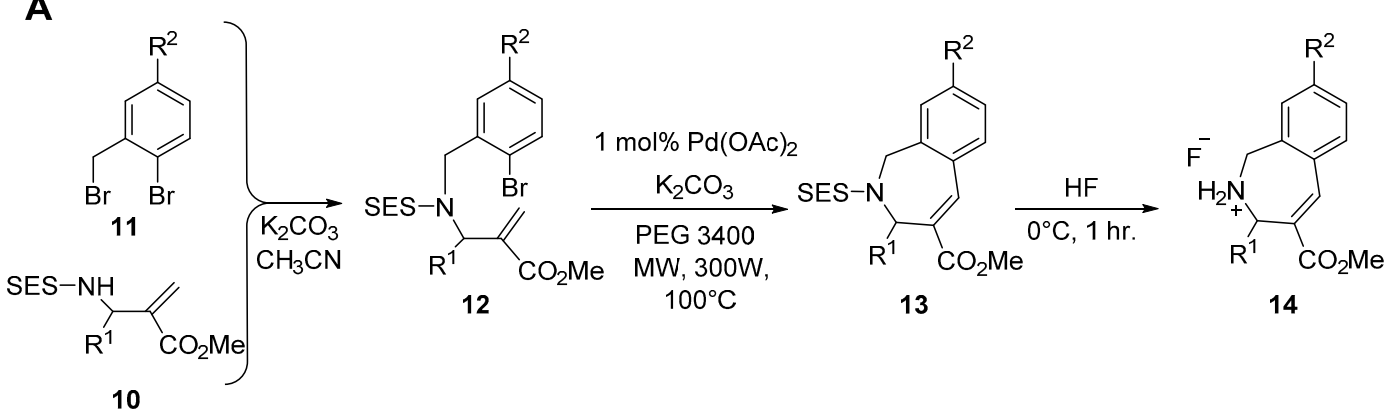

$\mathrm{R}^{1}=\mathrm{Aryl} ; \mathrm{R}^{2}=\mathrm{H}, \mathrm{OMe}, \mathrm{F} \quad \mathrm{PEG}-\mathrm{OH}=\mathrm{H}-\left(\mathrm{OCH}_{2} \mathrm{CH}_{2}\right) \mathrm{n}-\mathrm{OH}$

SES $=2$-(trimethylsilyl)ethanesulfonyl

B

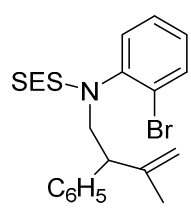

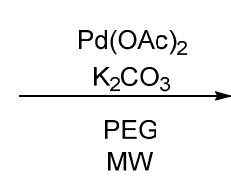

$\mathrm{Pd}(\mathrm{OAc})_{2} 10 \%, \mathrm{PEG} 3400, \mathrm{MW}, 100^{\circ} \mathrm{C}, 30 \mathrm{~min}$. Pd(OAc) $21 \%$, PEG3400, MW (300W), $100^{\circ} \mathrm{C}, 30 \mathrm{~min}$ $\mathrm{Pd}(\mathrm{OAc})_{2} 10 \%, \mathrm{PEG} 300, \mathrm{MW}(300 \mathrm{~W}), 100^{\circ} \mathrm{C}, 30 \mathrm{~min}$. $\mathrm{Pd}(\mathrm{OAc})_{2} 10 \%, \mathrm{PEG} 3400+\mathrm{PEG} 300, \mathrm{MW}(300 \mathrm{~W}), 100^{\circ} \mathrm{C}, 30 \mathrm{~min}$.
Heck coupling<smiles>CCCCC1C(C(=O)OC)=Cc2ccccc2CN1S#[S-]</smiles>

$\%$ 80
100

Scheme 1. Heck reaction leading to 2-benzazepines.

Interestingly, the profile of the temperature ramp exerts a strong influence on the chemoselectivity of this reaction. Indeed, two by-products resulting from a Tsuji-Trost rearrangement reaction have been observed (Scheme 1B). The highest rate of formation for these by-products occurs when the synthesizer's heating power at starting is not set to its maximum (300 W). In this case, several minutes are required to reach the appropriate temperature for the reaction. Moreover, the heating is delayed due to the time needed for the melting of PEG3400 $\left(58-65^{\circ} \mathrm{C}\right)$. This induces an inhomogeneity of the heating, leading to difficulties in reproducing the experiments. On the other hand, the use of low molecular weight PEGs (PEG300), which is not solid at room temperature, or the addition of DMF, leads to complicated mixtures of products.

Finally, the authors demonstrated that using PEG3400 as solvent in presence of $\mathrm{K}_{2} \mathrm{CO}_{3}$ as base and $1 \%$ of $\mathrm{PdOAc}_{2}$ as catalyst, under $\mathrm{MW}$-irradiation $\left(300 \mathrm{~W}, 100{ }^{\circ} \mathrm{C}\right)$, results in the formation of the expected 2-benzazepine in $30 \mathrm{~min}$, without formation of by-products. The conversion rates are good (up to $80 \%$ ), and the work-up conditions are simplified (precipitation of the PEG/Pd/base through addition of diethyl ether). Moreover, the catalytic system can be recycled, even if the conversion rates are reduced during the second reaction cycle.

The 6,7-dihydro-5H-dibenzo[c,e]azepines are structurally-related to the natural 5,6,7,8-tetrahydrodibenzo[c,e]azocine skeleton, an unusual motif which consists on a biarylic ring system linked through a 8 or 7 membered $N$-heterocycle. This core has been described 
in the structure of few natural products, whose leading members are (i) apogalanthamine (15), an alkaloid from the Amaryllidaceae family and (ii) buflavine (16), a natural extract from Boophane flava (Figure 2) [11,12].

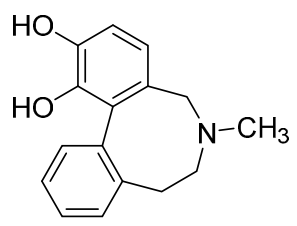

15, Apogalanthamine

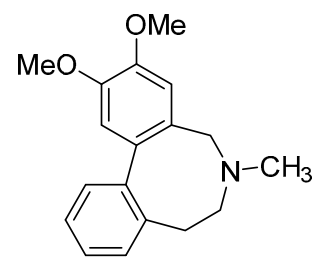

$\mathrm{R}=\mathrm{Me}:$ 16, Buflavine

Figure 2. Representative examples of bioactive 5,6,7,8-tetrahydrodibenzo[c,e]azocine.

An interesting synthesis of this scaffold has been reported by Van der Eycken's group at Leuven. The two key steps of this synthesis are (i) a Suzuki-Miyaura cross-coupling reaction; and (ii) an $\mathrm{A}^{3}$ intramolecular coupling reaction, each of which occurs under MW-activation (Scheme 2) [13,14]. Remarkably, despite of the electronically unfavourable combination of the $o$-bromobenzylamine 18 and the electron-poor $o$-formylarylboronic acid 19, the MW-activation of the Suzuki coupling leads to the biaryl 20 (95\% yield) in only $15 \mathrm{~min}$. In the next step, the coupling between the secondary amine, the aldehyde and the acetylenic derivatives (so-called $\mathrm{A}^{3}$ coupling), occurs under MW-irradiation using $\mathrm{Cu}(\mathrm{I})$ (20\% max.) as catalyst, and affords the required heterocyclic compounds 21 in 20-30 min and in high yields (up to $90 \%$ ). For this latter step, $\mathrm{CuI}, \mathrm{CuBr}$ and $\mathrm{CuCl}$ can be used as $\mathrm{Cu}^{\mathrm{I}}$ salts; interestingly, a decrease of the catalyst amount results in increased reaction times, but not in decreased conversion rates.

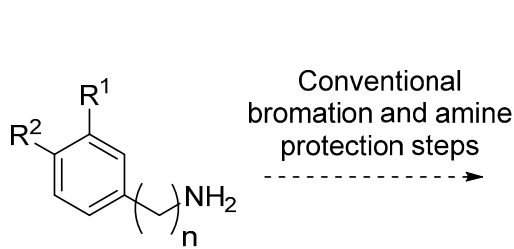

17

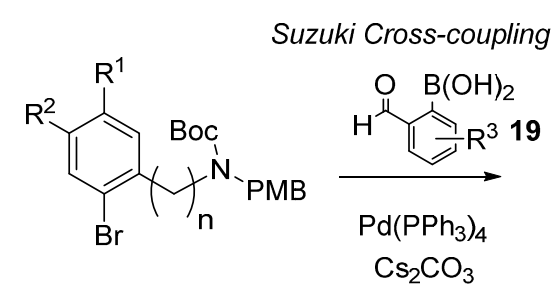

18

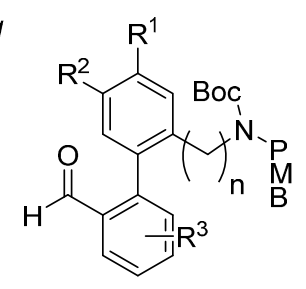

20 $15 \mathrm{~min}$.<smiles>[R]c1cc(-c2ccccc2C(=O)O)c(CC(C)(C(=O)OC(C)(C)C)N(C)C(C)(C)C)c([R])c1[R]</smiles>
20

$$
\begin{array}{ll}
\mathrm{R}^{1}=\mathrm{H}, \mathrm{OMe} & \mathrm{R}^{2}=\mathrm{F}, \mathrm{OMe} \\
\mathrm{R}^{3}=\mathrm{H}, \mathrm{Me} & \mathrm{R}^{4}=\text { alkyl, aryl }
\end{array}
$$

2) $\mathrm{R}^{4}=-\mathrm{H}$
Cul or $\operatorname{CuBr}(15 \%-20 \%)$ $\mathrm{MW}, 80 \mathrm{~W}, 100^{\circ} \mathrm{C}$ 15-30 min.

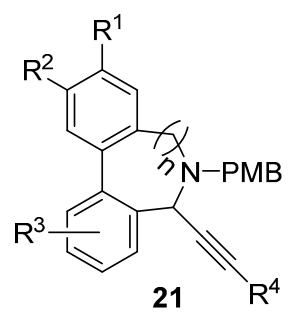
15 samples

Scheme 2. Suzuki-Miyaura reaction/ $\mathrm{A}^{3}$ coupling sequence leading to 2- and 3-benzazepines.

\section{3-Benzazepines and Their Derivatives}

The use of MW-activation for the synthesis of 3-benzazepines and derivatives has been extensively studied by Van der Eycken, as illustrated by an elegant asymmetric approach towards the alkaloid (-)-aphanorphine (24), which is structurally-related to two analgesics: pentazocine (23) and eptazocine (22) (Figure 3). 
<smiles>CN1CCC2(C)C[C@H](Cc3ccc(O)cc32)C1</smiles>

22, eptazocine

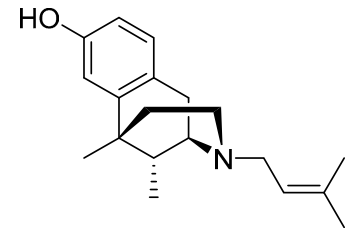

23, pentazocine

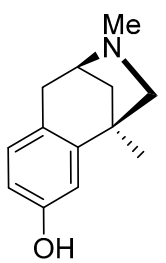

24, (-)-aphanorphine Natural product from Aphanizomenon flos-aquae

Figure 3. Representative examples of bioactive 3-benzazepines.

In this synthesis, the MW-assisted Heck reaction allowed the cyclisation of the 3-benzazepine ring 27, as outlined in Scheme 3 [15]. This intramolecular coupling has been carried out by applying a maximum power level of $300 \mathrm{~W}$ at $100{ }^{\circ} \mathrm{C}$ for $20 \mathrm{~min}$, in presence of Hermann's palladacycle as catalyst (2.5\%) and $\mathrm{NaHCO}_{2}$ as reducing agent.

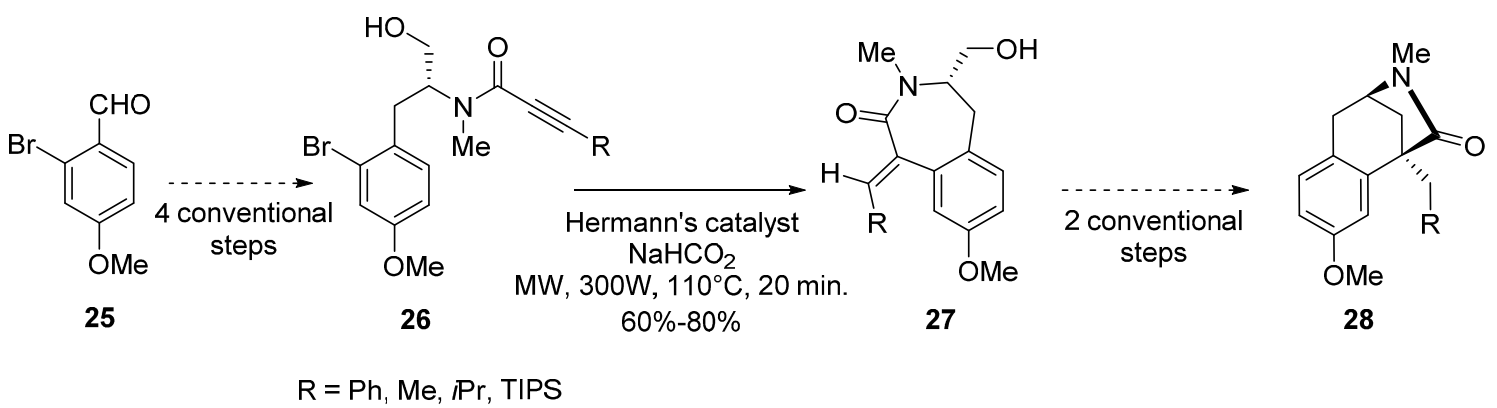

Scheme 3. Synthesis of 3-benzazepines through Heck intramolecular reaction.

The expected benzazepines have been isolated in good yields ( $60 \%-80 \%)$. Nevertheless, when the alkyne is substituted by a bulky group (26, $R=$ TIPS), these MW conditions gave benzazepine 27 in only $7 \%$ yield. This is probably due to the reduction of the bromine, and its subsequent elimination. For this specific case, the cyclisation required the use of standard conditions $\left(65^{\circ} \mathrm{C}\right.$, conventional heating for $5 \mathrm{~h}$ ) to reach $70 \%$ yield.

In the same group, Peshkov and co-workers have reported a fully-stereoselective two-step synthesis of 3-benzazepines, through an $\mathrm{A}^{3}$ multi-component coupling/intramolecular cyclisation sequence; each step of this sequence occurs under MW irradiation. Indeed, the first $\mathrm{A}^{3}$-coupling consists on mixing the aldehyde 29 , the alkyne $\mathbf{3 0}$ and the amine $\mathbf{3 1}$ in presence of $\mathrm{Cu}(\mathrm{I})$ catalysis $(\mathrm{CuI}$ or $\mathrm{CuBr}, 15 \%)$ and under $\mathrm{MW}$-irradiation $\left(90^{\circ} \mathrm{C}, 50 \mathrm{~W}, 30 \mathrm{~min}\right)$. This reaction affords the functionalized propargylamines 32 in high yields (73\%-95\%). Importantly, this $\mathrm{A}^{3}$ coupling doesn't occur under conventional heating. In the second step, the propargylamines 32 undergo a stereoselective $\mathrm{Pd}$-catalysed $\left(\mathrm{PdPPh}_{3}, 3 \%\right)$ intramolecular hydroarylation reaction of the acetylene group under MW-irradiation $\left(110^{\circ} \mathrm{C}, 100 \mathrm{~W}, 15 \mathrm{~min}\right)$, leading to the expected 3-benzazepines in $32-91 \%$ yield (33, Scheme 4) [16]. 

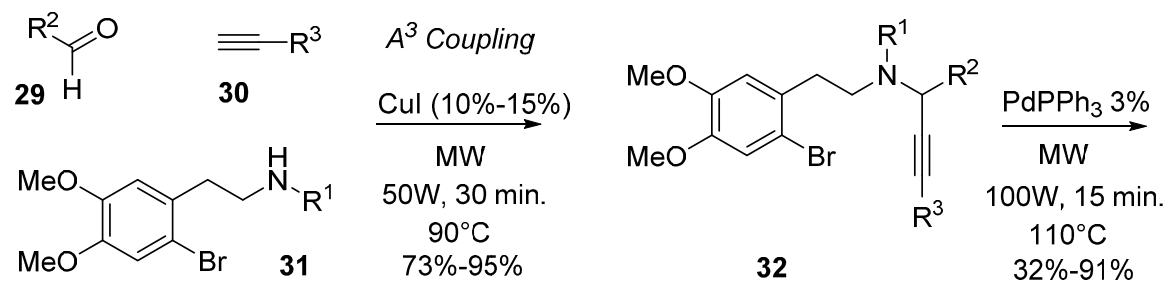<smiles>[R]C=C1c2cc(OC)c(OC)cc2CCN([R])C1[R]</smiles>

33

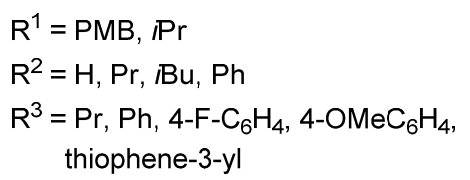

Scheme 4. $\mathrm{A}^{3}$ coupling/Pd-catalyzed cyclization sequence leading to 3-benzazepines.

The mechanism of the cyclisation step is outlined in Scheme 5. In this hypothetic pathway, the arylpalladium $\pi$-complex $\mathbf{I}_{2}$ undergoes a syn-addition to the triple bond leading to the $\sigma$-vinyl palladium complex $\mathbf{I}_{3}$. The authors hypothesized that the high strain exerted by the trans-geometry around the double bond prevents the endo-cyclisation through the potential complex $\mathbf{I}_{\mathbf{2}}{ }^{\prime}$. Therefore, this synthesis is fully stereoselective, leading only to an exocyclic bond with a Z-configuration.<smiles>[R]C=C1C([R])=C([R])CCN1[Tl]</smiles>

33<smiles>CC(C)C</smiles>

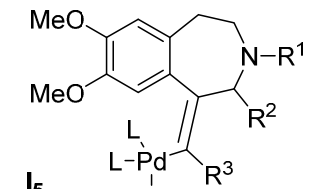
$I_{5}$

$\mathrm{H}$

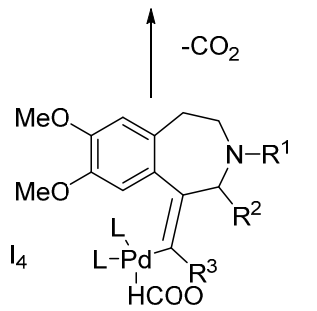<smiles>CC</smiles>
$\mathrm{HCO}_{2} \mathrm{Na}$

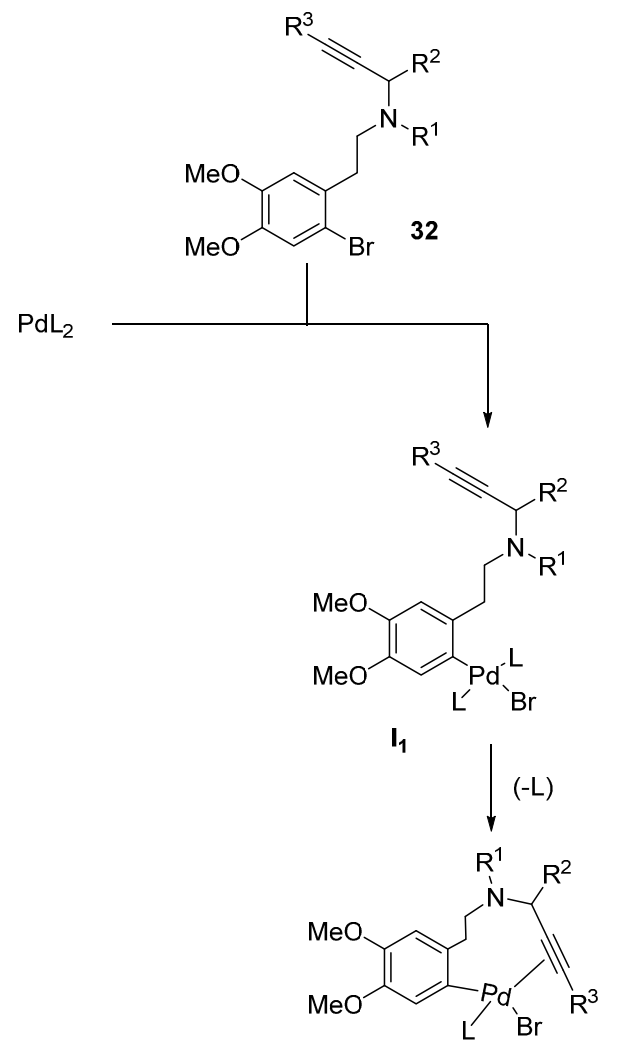

$I_{2}$

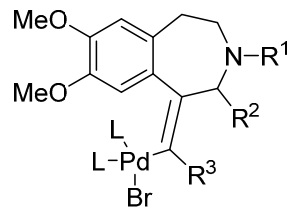

$\mathbf{l}_{3}$

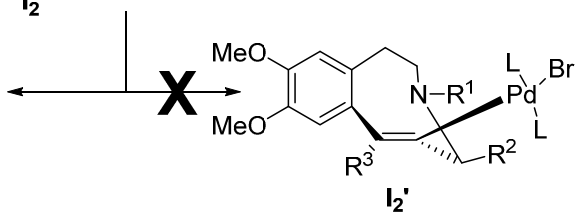

Not formed

Scheme 5. Mechanistic study of the 3-benzazepines synthesis reported by Peshkov and co-workers [16]. 
An alternative route to 3-benzazepines consists on the use of 3-benzazepin-2-ones as key intermediates. In a study reported by Sarkat and co-workers [17], the condensation of aromatic keto acids 34 with primary amines afforded the 3-benzazepin-2-ones 35 . The use of conventional heating (refluxing toluene), large excess of amine (up to 10 eq.) and/or long reaction times (more than 3 days) yields the required products in only 20\% in the best cases. By a marked contrast, MW-activation ( $150 \mathrm{~W}, 5$ bars) leads to the heterocycles in only $3 \mathrm{~h}$ with improved conversion rates $(30 \%-60 \%$ yield). Importantly, the formation of the 3-benzazepinone does not occur when using a primary amine bearing two substituents in the $\alpha$-position. For example, when using (S)-1-phenylethylamine, the authors reported the formation of the indalone 38 instead of the expected seven-membered heterocycle. In this case, the authors hypothesized that the double bond of the intermediate enamine 37 reacted faster with the carboxyl group than the amino moiety.

Lastly, the hydrogenation of the 3-benzazepinones 35 in presence of $\mathrm{Pd} / \mathrm{C}$ followed by the reduction of the lactam, using $\mathrm{BH}_{3}$. THF complex, leads to racemic 2,3-disubstituted tetrahydro-3-benzazepines 36 in good yields. These molecules have been studied as ligands for the $\sigma 1$ receptor, which is distributed in the central nervous system as well as tissues like kidney, liver, lung and heart. The leading compound binds this receptor with a $K_{i}=12 \mathrm{nM}$, underlying the potencies of the 3-benzazepine scaffold for the design of new therapeutic agents directed toward CNS disorders (Scheme 6) [17].

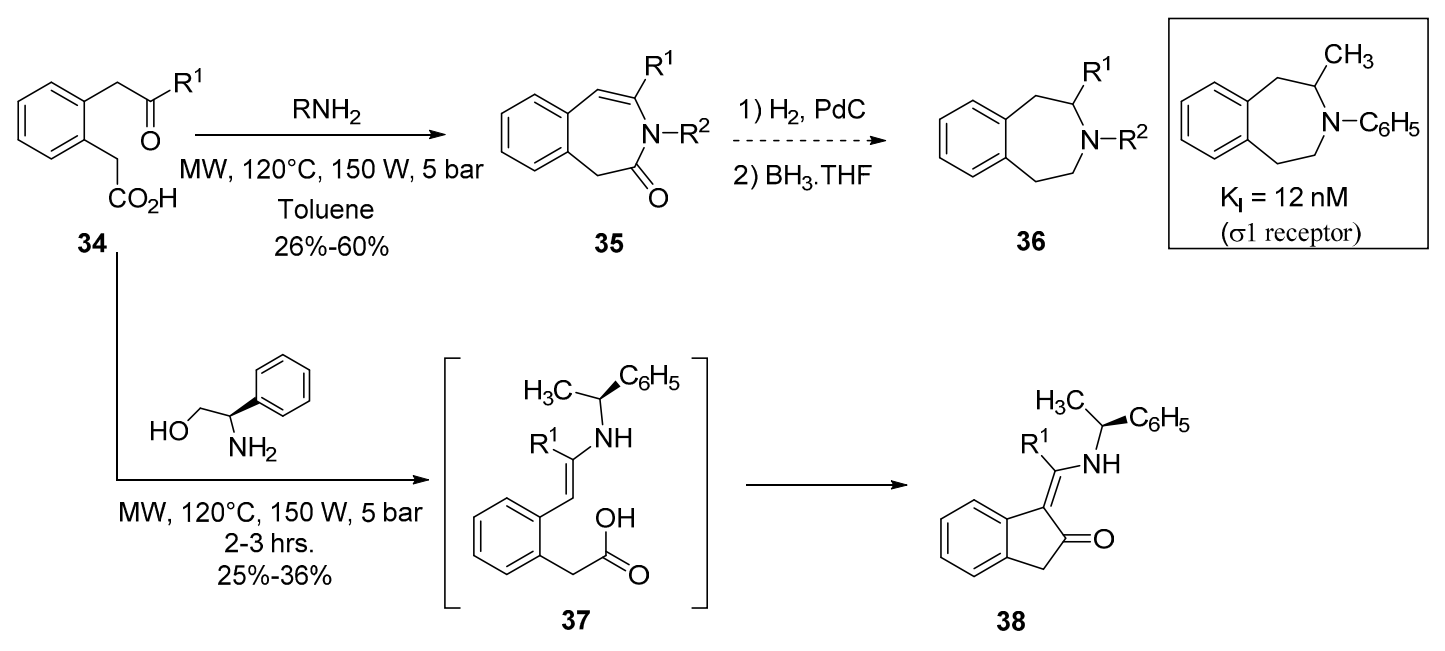

Scheme 6. MW-assisted synthesis of 3-benzazepines and indalones with a potential activity against CNS disorders.

\section{Oxepanes, Thiepanes and Their Derivatives}

The benz $[b]$ oxepines form a class of seven-membered heterocycles, containing one oxygen atom, which are fused to an aromatic moiety. This scaffold arises only in a small set of bioactive natural products produced by plants (Figure 4) [18-21].<smiles>Cc1cc2c(cc1O)[C@@H](C)CC[C@@H](C(C)(C)O)O2</smiles>

39, Heliannuol D Herbicide (allelochemical) Extracted from Helianthus annuus

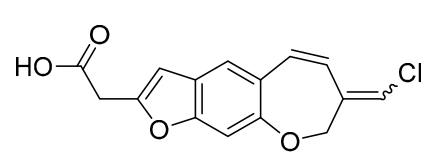

40, Pterulinic acid NADH inhibitor and anti-fungal Issued from Pterula species<smiles>CC(O)[C@]1(O)COc2c(O)cccc2C(O)C1</smiles>

41, Xylarinol Extracted from Xylaria polymorpha

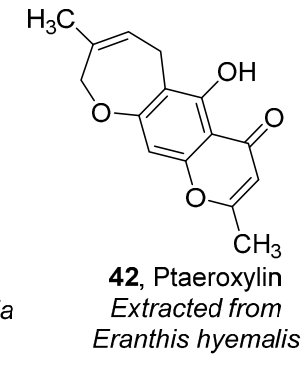

Figure 4. Relevant examples of bioactive benz $[b]$ oxepines. 
To the best of our knowledge, very few syntheses of benz[b]oxepines have been reported. In this context, the efficient domino-strategy elaborated by Jiang and co-workers leading to series of $([3,4]$ furanimino)benzo[e]pyrano[4,3-b]oxepines is a remarkable exception [22]. In this approach, the one-pot, $\mathrm{MW}$-assisted, multi-component reaction involving $o$-phtalaldehyde 43, 4-hydroxy-6-methyl-2H-pyranone 44 and $\mathrm{N}$-substituted 4-aminofuran-2(5H)-ones 45 leads to a series of pentacyclic pyrano[4,3-b] oxepines 46 (Scheme 7A) in high yields (up to 70\%) and short reaction times (less than $30 \mathrm{~min}$ ). According to the authors' hypothesis, the reaction occurs through a first [ $4+3$ ] cycloaddition between the $o$-phtalaldehyde $\mathbf{4 3}$ and the aminofuranone 45 leading to the azapinediol $\mathbf{I}_{\mathbf{1}}$ which undergoes next a double intramolecular nucleophilic substitution leading to the pentacyclic pyrano[4,3-b]oxepines 46 . This reaction occurs with remarkable chemo-, stereoand regioselectivities (Scheme 8). It is to note that, by a similar way, a series of multi-functionalized pyrano $\left[3^{\prime}, 2^{\prime}, 2,3\right]$ indeno[2,1]quinolones 48 (Scheme 7B) has been obtained using six-membered cyclic enaminones 47 instead of the aminofuranone 45.

A

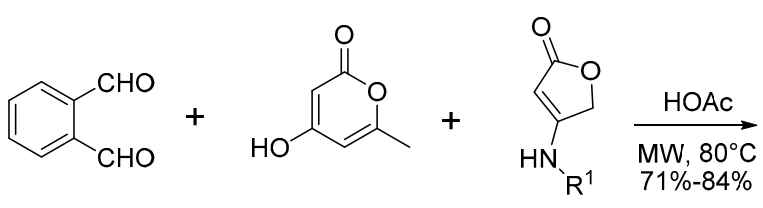
43 44 45

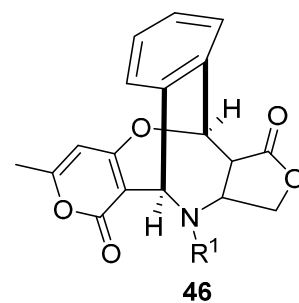

7 examples

B<smiles>O=Cc1ccccc1C=O</smiles>
43<smiles>Cc1cc(O)cc(=O)o1</smiles>
44<smiles>[R]NC1=CC(=O)CC([R])([R])C1</smiles>
47

$\mathrm{R}^{1}=$ Aryl $\mathrm{R}^{2}, \mathrm{R}^{3}=\mathrm{H}, \mathrm{CH}_{3}, \mathrm{Ph}$

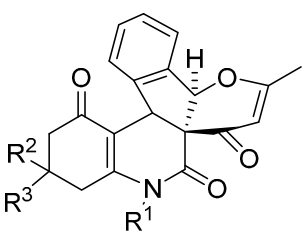

16 examples

Scheme 7. One-pot, multi-component reaction leading to pentacyclic pyrano[4,3-b]oxepines.

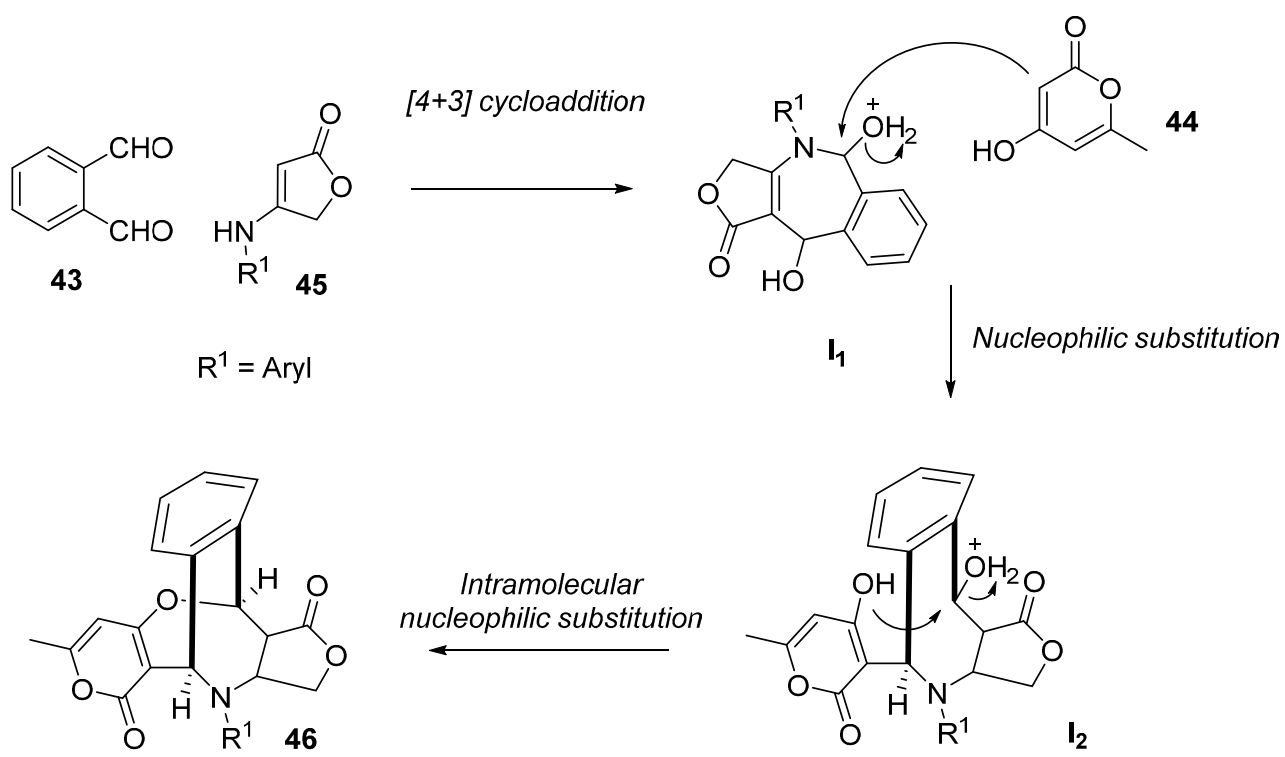

Scheme 8. Mechanistic study of the benz[b]oxepines synthesis reported by Jiang and co-workers [22]. 
Another interesting route to benzoxepines has been proposed by Moody's group, which reported the synthesis of the ptaeroxilin $\mathbf{5 2}$ and its derivatives. These molecules belong to the family of the natural oxepinochromones. However, these authors do not take advantage of the MW-irradiation for the closure of the seven-membered heterocycle, but they used a MW-assisted Claisen re-arrangement, which occurs concomitantly with a Boc deprotection leading to the key intermediate 51 (Scheme 9) [23].

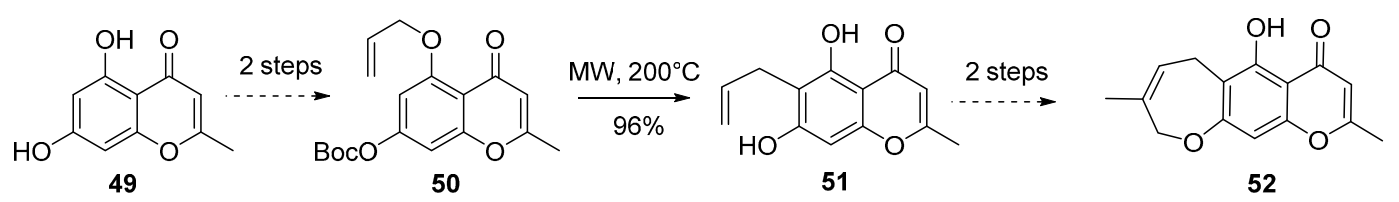

Scheme 9. Synthetic route to ptaeroxilin involving a MW-assisted Claisen rearrangement step.

The dibenz $[b, f]$ oxepines are characterized by an oxepane fused with two aromatic moieties: this is a relevant pharmacophore present in the structure of numerous therapeutic agents which can be used for several therapeutic applications such as antidepressant, antipsychotic and anti-inflammatory indications (Figure 5) [24-28].

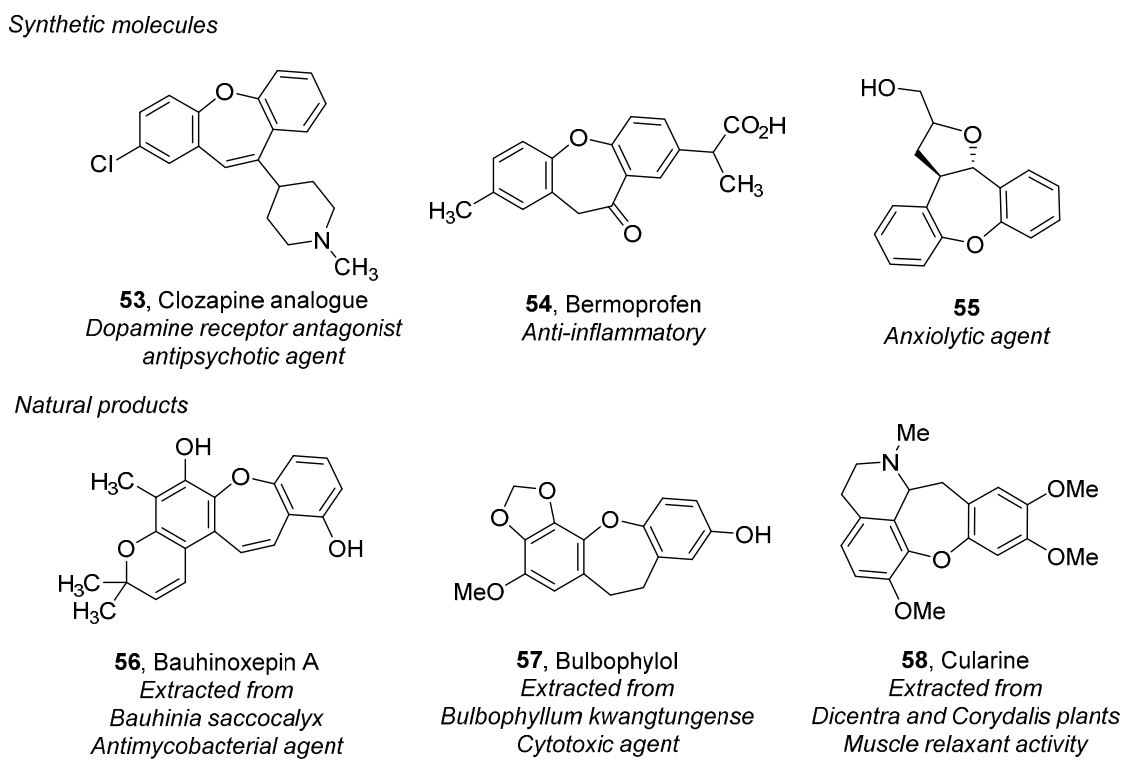

Figure 5. Relevant examples of bioactive dibenz $[b, f]$ oxepines.

Very few MW-assisted syntheses of dibenzoxazepines have been reported. Nevertheless, two very interesting approaches, based (i) on an intramolecular $\mathrm{S}_{\mathrm{N}} \mathrm{Ar}$; and (ii) on a McMurry reaction, each occurring with MW-activation, have been described by Moreno and co-workers [29] (Scheme 10A).

The $S_{N}$ Ar strategy requires the synthesis of a multi-functionalized Z-stilbene 61, which is obtained in $87 \%$ yield through a conventional Wittig reaction involving o-bromobenzyl-triphenylphosphonium salt 60 and 2-formylphenyl-4-methylbenzene sulfonate 59. Subsequent cleavage of the $p$-toluenesulfonate group leads to a Z-stilbene $\mathbf{6 1}$, which undergoes an intramolecular $\mathrm{S}_{\mathrm{N}} \mathrm{Ar}$ reaction under MW-irradiation. The resulting dibenzo[ $[b]$ oxepin 62 is obtained in $72 \%$ yield (Scheme 10B).

The alternative strategy consists of the intramolecular McMurry condensation of aromatic diaryl ethers 65. These intermediates are synthesized in high yields (up to $75 \%$ ) through $\mathrm{MW}$-assisted $\mathrm{S}_{\mathrm{N}} \mathrm{Ar}$ reactions, carried out at $120^{\circ} \mathrm{C}$ in DMSO or DMA and in the presence of $\mathrm{K}_{2} \mathrm{CO}_{3}$ or $\mathrm{Cs}_{2} \mathrm{CO}_{3}$ as base (2.0 eq.) (Scheme 10C). It is important to note that, in this case, the $\mathrm{S}_{N} \mathrm{Ar}$ reaction could also be performed under conventional heating but under harsher conditions that generally lead to low conversion rates and poor yields. 
A. Strategies for the synthesis of functionalized dibenzoxazepines

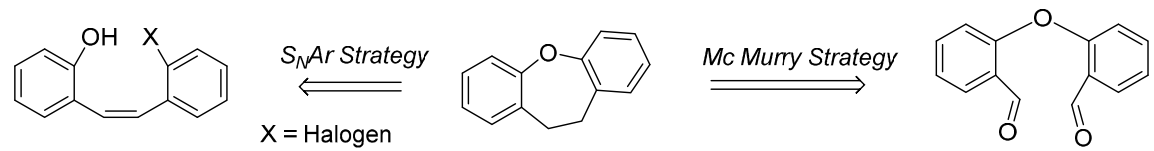

B. Synthesis of dibenzoxepin $\mathbf{6 2}$ by intramolecular $S_{N} A r$ reaction<smiles>O=Cc1ccccc1OC(F)(F)F</smiles>

59<smiles>BrCPCc1ccccc1Br</smiles>

60

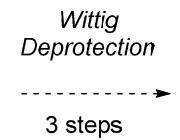

3 steps

C. Synthesis of dibenzo[b,f]oxepin scaffold via McMurry reaction

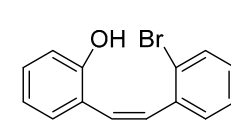

61

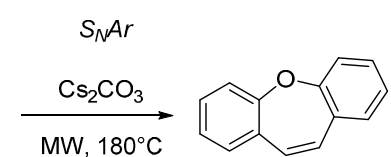

62<smiles>O=Cc1ccccc1O</smiles>

63<smiles>[R]c1cccc(F)c1C=O</smiles>

64

$S_{N} A r$

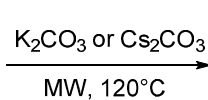

$30 \mathrm{~min}$.

$73 \%-82 \%$<smiles>[R]c1cccc(Oc2cccc([R])c2CO)c1C</smiles>

65

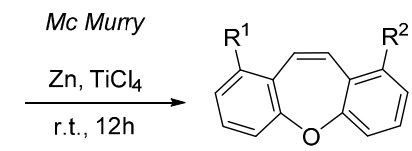

66

$\mathrm{R}^{1}=\mathrm{H}, \mathrm{OMe}$

$\mathrm{R}^{2}=\mathrm{H}, \mathrm{F}$

Scheme 10. Two MW-assisted synthesis of functionalized dibenzoxazepines.

The dibenzo $[b, f]$ thiepines are a pharmacologically relevant family of seven-membered heterocycles containing one sulfur atom. Indeed, several examples of dibenzo $[b, f]$ thiepines with anti-bacterial, anti-psychotic, neuroleptic or anti-proliferative activities have been highlighted in the literature as illustrated in Figure 6 [30-32].

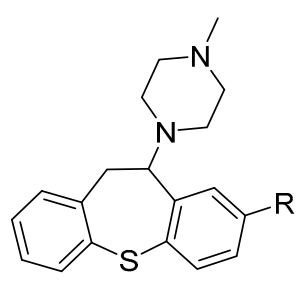

67, $\mathrm{R}=\mathrm{Cl}:$ Octoclothepin 68, $\mathrm{R}=\mathrm{SCH}_{3}:$ Methiothepin Antibacterial, neuroleptic

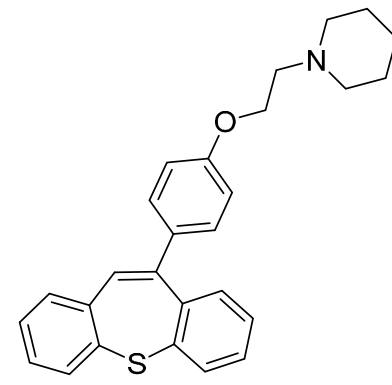

69

Cytotoxic agent<smiles>CN(C)CCOC1=Cc2ccccc2Sc2ccc(Cl)cc21</smiles>

70, Zotepine Antipsychotic

Figure 6. Relevant examples of bioactive dibenzo $[b, f]$ thiepines.

Nevertheless, at the best of our knowledge, only one example of MW-assisted synthesis of a dibenzo[b $f]$ thiepine has been reported in the literature. The originality of this strategy, disclosed by Bozinovic and co-workers [33,34], consists in the use of potassium thioacetate (KSAc) as a sulfur source for a double palladium-catalyzed C-S bond formation (Scheme 11). Indeed, the use of this reactant on functionalized stilbenes $\mathbf{7 3}$ (accessible through conventional Wittig reactions) in presence of a suitable mixture of $\operatorname{Pd}(0)$ catalyst and ligand, affords the required dibenzo[b,f]thiepines $\mathbf{7 4}$. The use of MW-activation for this double C-S bond formation reduces the reaction times (from $14 \mathrm{~h}$ to $90 \mathrm{~min}$ ) and improves the conversion rates (from 30\% to 50\% approx.). Interestingly, this coupling is compatible with different sources of $\mathrm{Pd}(0)$, including $\mathrm{Pd}(\mathrm{OAc})_{2}$ and $\mathrm{Pd}_{2} \mathrm{dba}_{3}$, but is less versatile regarding the nature of the ligand. For example, no reaction occurs in presence of JohnPhos, a ligand that has been successfully used for a similar palladium-catalyzed double amination-cyclization reaction leading to corresponding azepines derivatives. In this context, the authors point out the relevance of 1,1'-bis(diphenylphosphino)ferrocene (dppf) as the suitable ligand for this double C-S bond formation. 


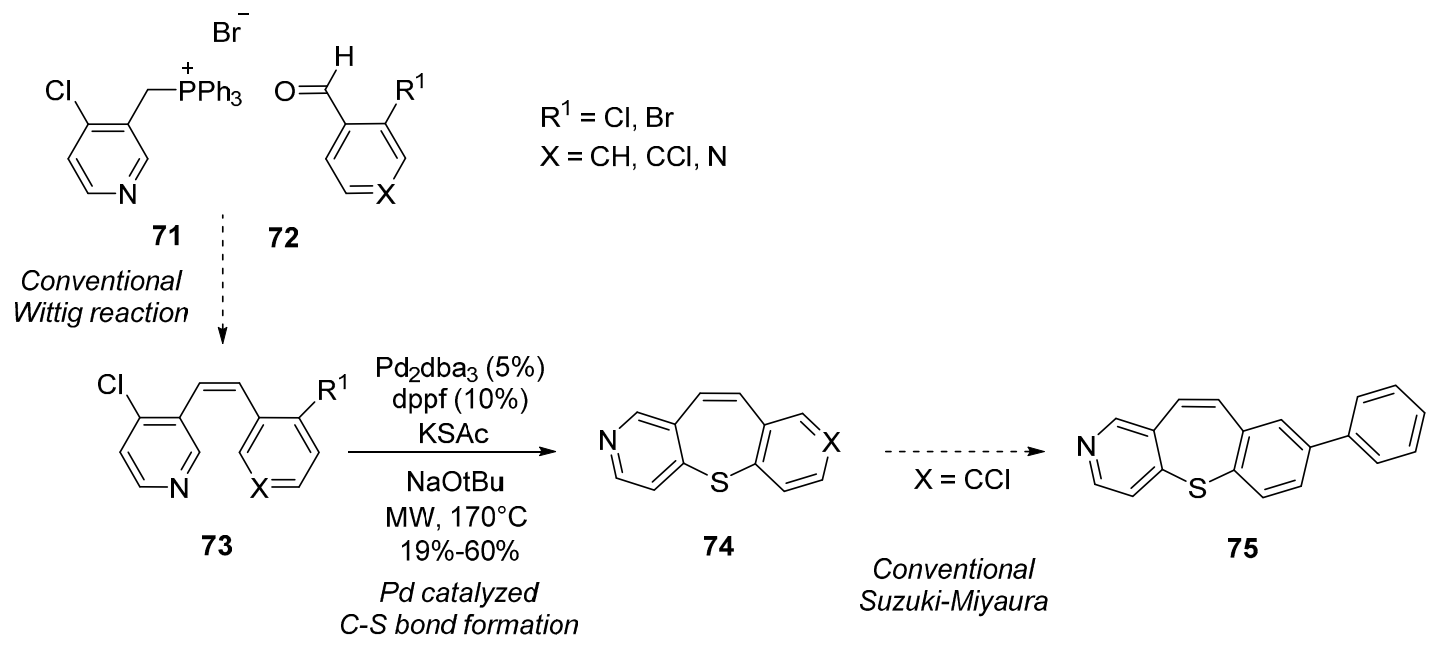

Scheme 11. Synthesis of dibenzo[b,f]thiepines by means of a Pd-catalyzed double C-S bond formation.

In the next steps, the dibenzo $[b, f]$ thiepines have been converted into the biphenyl derivatives 75 through conventional Suzuki-Miyaura cross coupling reactions. Among the final compounds, several molecules exhibited significant anti-fungal activities, in particular against S. cerevisiae and A. brasiliensis.

\subsubsection{Seven-Membered Heterocycles with Two Heteroatoms}

Seven-Membered Heterocycles with Two Nitrogen atoms

The diazepines and benzodiazepines form a class of seven-membered heterocycles, containing two nitrogen atoms, and fused with a benzenic core. Depending of the relative positions of the nitrogen atoms, several classes of diazepines and benzodiazepines are described. The benzodiazepines have been frequently used in drug design as $\beta$-turn or $\alpha$-helix mimetics, and these motives are also used to constrain peptidic sequences. Therefore, this scaffold is considered as a privileged pharmacophore (Figure 7) [35-37].

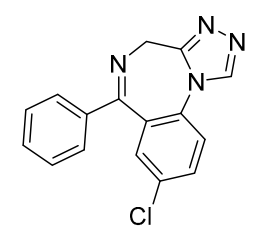

76, Estazolam sedative and anti convulsant<smiles>CN1C(=O)CN=C(c2ccccc2)c2cc(Cl)ccc21</smiles>

77, Diazepam sedative

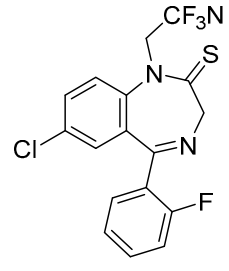

78, Quazepam hypnotic

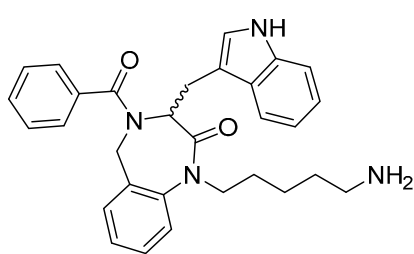

80

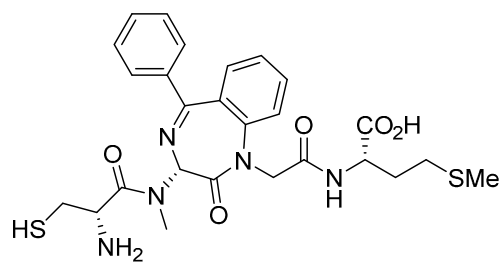

79 peptidomimetic RAS-farnesyl transferase inhibitor

Somatostatin mimics

Figure 7. Relevant examples of bioactive benzodiazepines.

In this context, interesting benzodiazepines preparations have been reported. However, the huge majority of these conventional syntheses are characterized by long reaction times, expensive reagents, harsh conditions, low-product yields, occurrence of several side products and difficulty to 
recover and/or re-use the catalysts. We report in this section new relevant examples of diazepines and benzodiazepines MW-accelerated synthesis, and their subsequent conversion and functionalization.

\section{Diazepines}

A simple MW-assisted synthesis of the 1,2-diazepines 84 based on the condensation of $\alpha, \beta$-unsaturated 1,5-diketones 83 with hydrazine has been reported by Manih et al. [38]. This reaction occurs at $110{ }^{\circ} \mathrm{C}$ in water and in the presence of polystyrene sulfonic acid (PSSA) as catalyst. The required products are isolated with high yields (up to $85 \%$ ) and in short reaction time (less than $10 \mathrm{~min}$ ). In this synthesis, the diketones have been obtained through the conventional condensation of acetophenones $\mathbf{8 1}$ with 1,3-diketones 82 (Scheme 12).

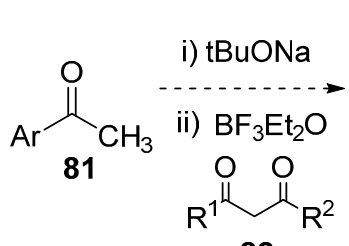

82<smiles>[R]C(=O)CC([R])=CC(=O)[Te]</smiles>

83

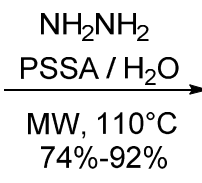

$74 \%-92 \%$

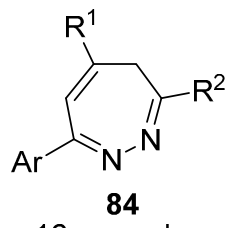

16 examples

$$
\begin{aligned}
& \mathrm{Ar}=\mathrm{C}_{6} \mathrm{H}_{5,} p-\mathrm{ClC}_{6} \mathrm{H}_{4,} p-\mathrm{BrC}_{6} \mathrm{H}_{4}, p-\mathrm{NO}_{2} \mathrm{C}_{6} \mathrm{H}_{4}, p-\mathrm{MeOC}_{6} \mathrm{H}_{4} \\
& \mathrm{R}^{1} \text { and } \mathrm{R}^{2}=\mathrm{Me}, \mathrm{C}_{6} \mathrm{H}_{5}
\end{aligned}
$$

Scheme 12. Intramolecular condensation of diketones in water and under polystyrene sulfonic acid leading to 1,2-diazepines.

Orelli and co-workers [39,40] have developed a synthetic route to a series of 1,3-diazepines starting from the $\mathrm{N}$-arylputrescine derivative $\mathbf{8 5}$, which is quantitatively converted into the key aminoamides 86 by means of conventional acylation reactions. In marked contrast to conventional cyclodehydration reactions leading to seven-membered amidines, which require long reaction times and drastic heating, the MW-assisted cyclodehydration of 86 using a $\mathrm{CHCl}_{3}$ solution of ethyl-polyphosphate (PPE), a mild "Lewis acid" irreversible dehydrating reagent, leads to corresponding 1-aryl-2-alkyl-1H-1,4,5,6-tetrahydro-1,3-diazepines 87 in $8 \mathrm{~min}$ at $100{ }^{\circ} \mathrm{C}$ with good yields $(42 \%-90 \%)$ (Scheme 13$)$.

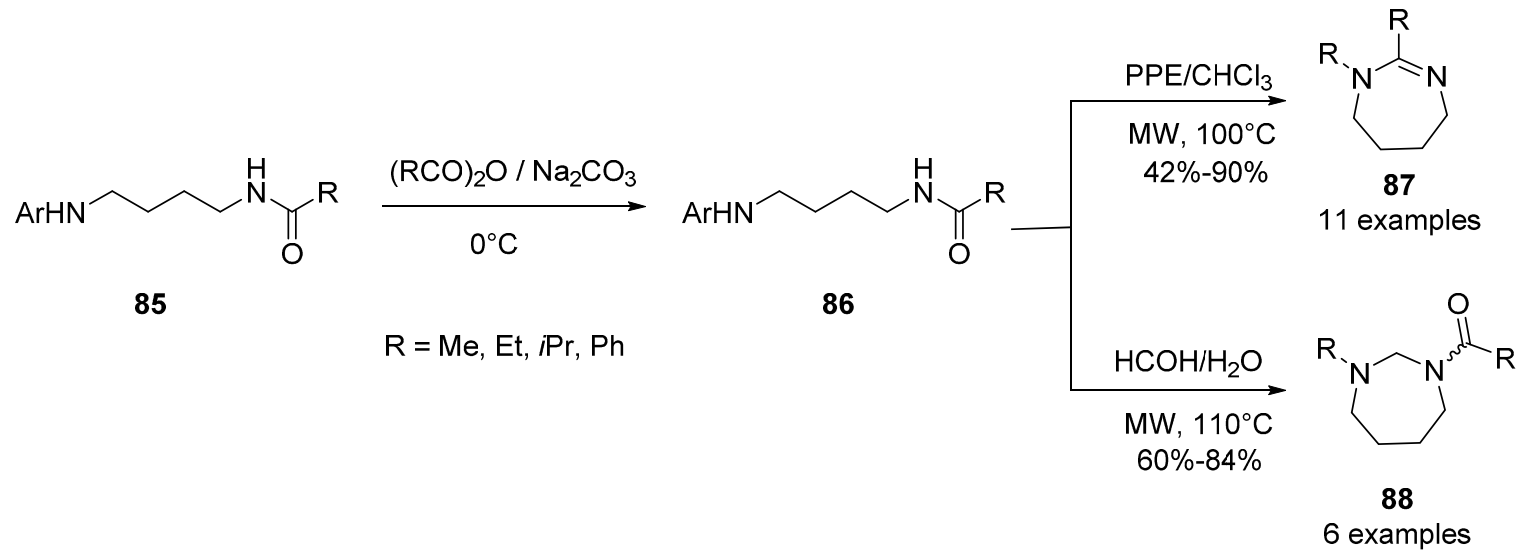

Scheme 13. Synthetic route to 1,3-diazepines via cyclo-dehydration of aminoamides.

Otherwise, the MW-assisted cyclo-dehydration of $\mathbf{8 6}$ with aqueous formaldehyde in methanol afforded $N$-acyl- $N^{\prime}$-arylhexahydro-1,3-diazepines 88 in only 2 min at $110{ }^{\circ} \mathrm{C}$ (Scheme 13).

A solvent-free synthesis of 1,4-diazepines has been recently reported by Petros and co-workers [41]. In this preparation, 2,2,6-trimethyl-4H-1,3-dioxin-4-one 89 (the so-called diketene acetone adduct, 
DDA) and linear bisamines 90 were condensed at $130{ }^{\circ} \mathrm{C}$ under $\mathrm{MW}$-irradiation in solvent-free conditions (Scheme 14).

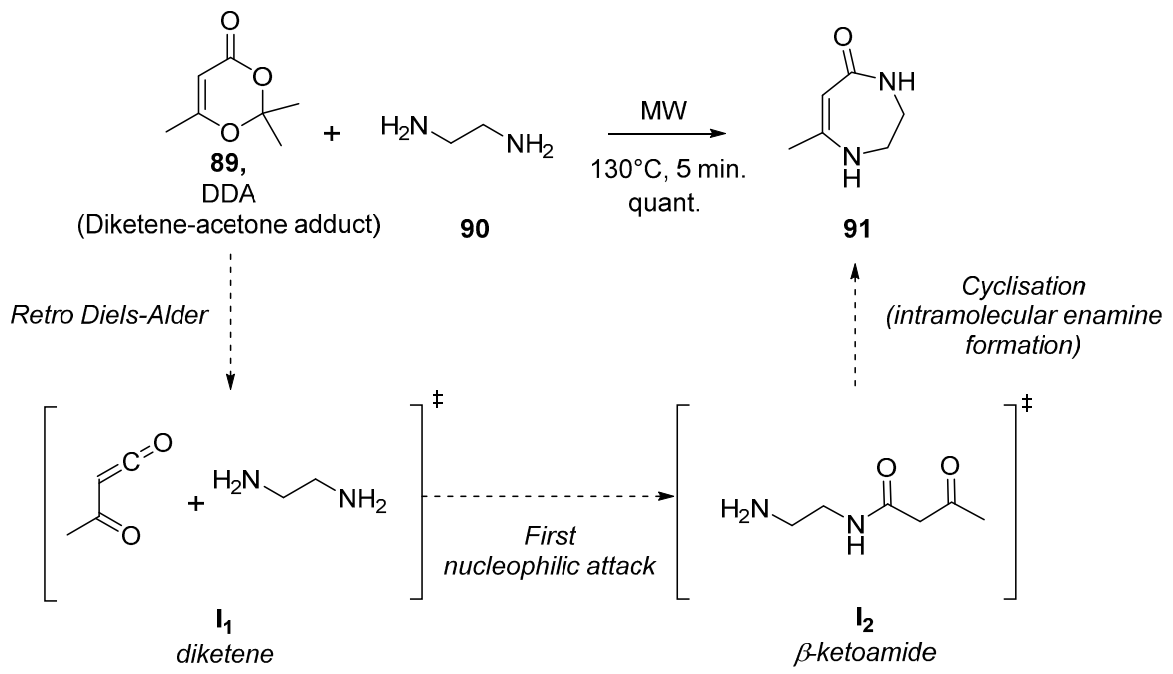

Scheme 14. Solvent-free synthesis of 1,4-diazepines through Retro Diels-Alder and intramolecular enamine formation.

The corresponding diazepines $\mathbf{9 1}$ are obtained in only five minutes. Acetone and water are the sole by-products and are easily removed from the reaction mixture. Mechanistically, the reaction begins with a retro-Diels-Alder reaction leading to the diketene $\mathbf{I}_{\mathbf{1}}$, which undergoes a nucleophilic attack by a linear bisamine to generate the intermediate $\beta$-keto amide $\mathbf{I}_{\mathbf{2}}$. This intermediate $\mathbf{I}_{\mathbf{2}}$ undergoes an intramolecular cyclization through enamine formation (Scheme 14).

Diazepines Fused with Five-Membered Cycles

An elegant two-step synthesis of pyrrole-fused 1,3-diazepines has been reported by Liang et al. [42]. Firstly, a one-pot three components reaction involving ethyl cyanoformate (92), thiophenol (93), and cyclic ketones 94 afforded the piperidyl 3-oxazolin-5-one 95 under MW-activation at $80{ }^{\circ} \mathrm{C}$, in the presence of $\mathrm{TiCl}_{4}$ and $\mathrm{BF}_{3} \cdot \mathrm{Et}_{2} \mathrm{O}$ as Lewis acid catalysts (Scheme 15). By a marked contrast with a conventional heating, the $\mathrm{MW}$-activation of this one-pot reaction allowed shortened reaction times (from $36 \mathrm{~h}$ to only $15 \mathrm{~min}$ ) and improved conversion rates (around 60\% under MW-irradiation).

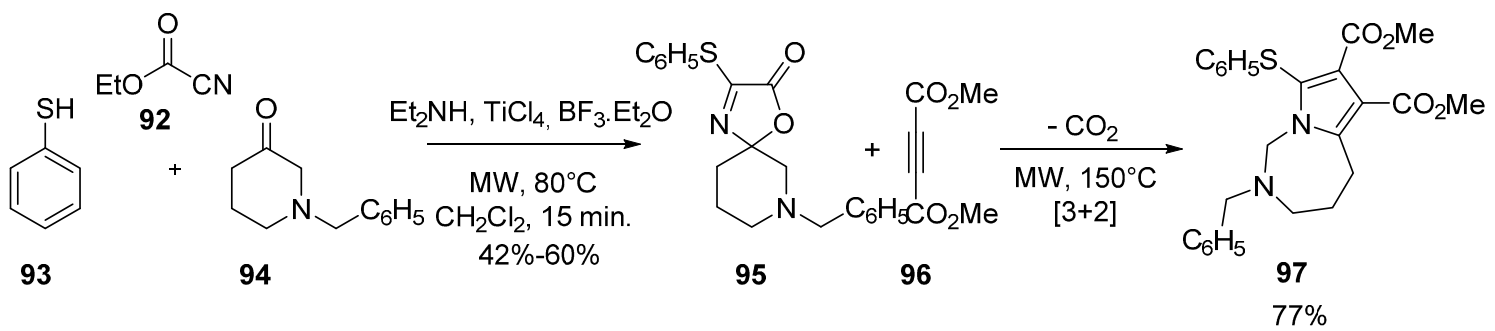

Scheme 15. One-pot, three components reaction leading to pyrrole-fused 1,3-diazepines.

In the second step, the oxazolinone 95 is decarboxylated under MW-irradiation at $150{ }^{\circ} \mathrm{C}$, resulting in the formation of a nitrile ylide $\left(\mathbf{I}_{\mathbf{1}}\right)$, which is trapped by a dipolarophile $\mathbf{9 6}$, by means of a [3 + 2] dipolar cycloaddition, leading to a transient spiro-fused cycle $\left(\mathbf{I}_{2}\right)$. This spiro intermediate is unstable, and a spontaneous retro-Mannich reaction leads in two steps to the pyrrolo[1,3]diazepine 97. This unprecedented domino-process under MW-activation has been exemplified using series of various electron-deficient alkynes as dipolarophiles (Scheme 16). 
decarboxylation

[3+2] dipolar cycloaddition

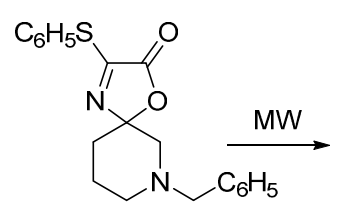

95

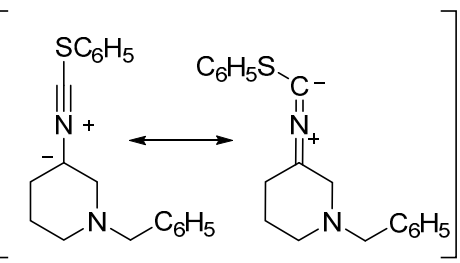

$I_{1}$, nitrile ylide

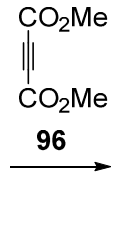

$\mathrm{CO}_{2} \mathrm{Me}$

6

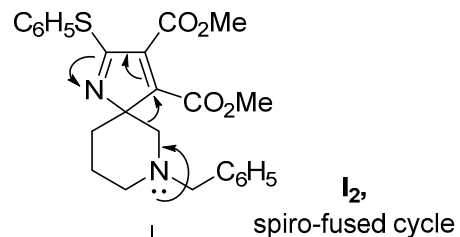

retro-Mannich

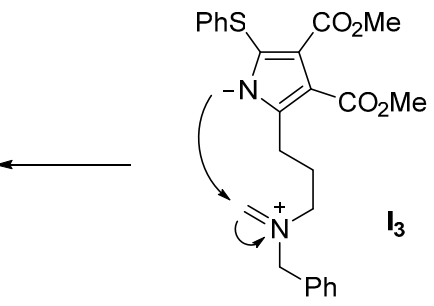

Scheme 16. Mechanistic study of the pyrrole-fused 1,3-diazepines synthesis reported Liang et al. [42].

A very useful synthesis of novel 2-ferrocenyl-7-hydroxy-5-phenethyl-5,6,7,8-tetrahydro-4Hpyrazolo[1,5- $a][1,4]$ diazepin-4-one derivatives 99 and 101 has been described by Shen et al. [43] (Scheme 17). These compounds have been synthesized through the reaction of $(R)$ or (S)-3-ferrocenyl-1-(oxiran-2-ylmethyl)-1H-pyrazole-5-carboxylates 98, 100, and substituted phenylethylamines. The reactions were performed under classical heating (in a sealed vessel) and MW-assisted heating (Scheme 17). MW-assisted solvent-free conditions provided the expected products with higher yields and shortened reaction times, related to the conventional ones [44].

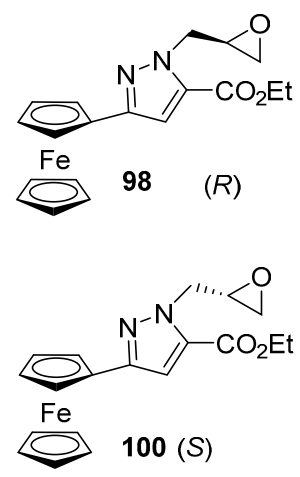

$\mathrm{R}=\mathrm{H}, 3-\mathrm{OMe}, 2-\mathrm{F}, 4-\mathrm{F}$
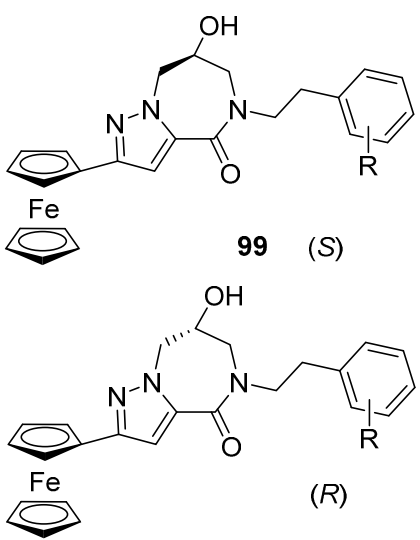

101, 8 examples $\Delta: 62 \%-82 \%$ MW : $72 \%-81 \%$

Scheme 17. MW-synthesis of 2-ferrocenyl-7-hydroxy-5-phenethyl-5,6,7,8-tetrahydro-4H-pyrazolo [1,4]diazepin-4-ones.

Cellular assays on selected human lung cancer cell lines showed that some of these newly synthesized compounds exerted anti-proliferative activity against A549, H322 and H1299. In addition, it appeared that the anti-cancer activity wasn't dependant of the chirality of the compounds $[43,44]$. 


\section{Benzodiazepines and Their Fused Analogues}

The first MW-assisted synthesis of benzodiazepine derivatives through the condensation of 1,2-phenylenediamine and ethyl acetoacetate was reported in 1994 by the Soufiaoui group [45]. This synthesis has been extensively studied [46,47] and among the newest optimizations, Vaddula and co-workers reported a MW-assisted solvent- and catalyst-free green procedure (Scheme 18), which results in the formation of a series of 1,4-benzodiazepines 104 [48]. This condensation consists on mixing o-phenylendiamine $\mathbf{1 0 2}$ and substituted $\beta$-diketones $\mathbf{1 0 3}$ to afford quantitatively in shortened reaction times the required benzodiazepines (yields up to $95 \%$ ). However, this reaction failed when using $\beta$-ketoesters or 3-chloropentane-2,4-dione.
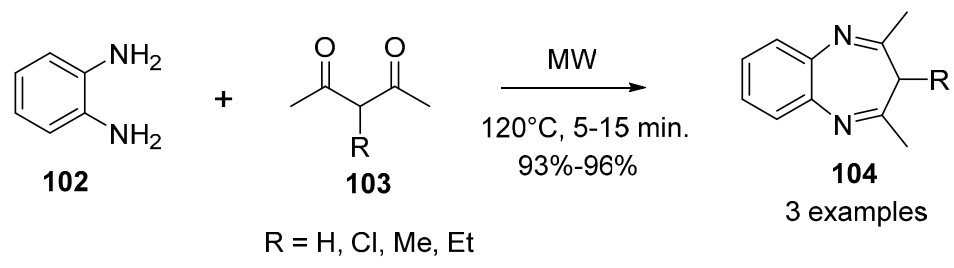

Scheme 18. Green synthesis of 1,4-benzodiazepines.

Willy and co-workers [49] have synthesized 2,4-disubstituted benzodiazepines 107 in good yields from acyl chlorides 105, alkynes 106, and benzene-1,2-diamines (o-phenylenediamines) by a consecutive one-pot, three-component Sonogashira coupling/Michael addition/cyclocondensation sequence. These diazepines display intense solid-state fluorescence, but only weak emission in solution at room temperature. The authors reported that heating under MW-irradiation $\left(120^{\circ} \mathrm{C}\right)$ led to expected products in shortened reaction times $(60 \mathrm{~min})$ and better yields $(40 \%-88 \%)$ compared to conventional reaction conditions, wherein the same products were obtained at $90^{\circ} \mathrm{C}$ in $16 \mathrm{~h}$ (Scheme 19).

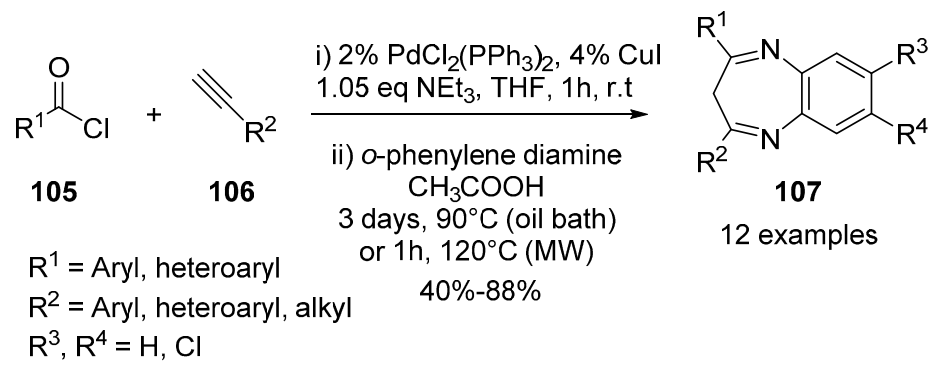

Scheme 19. One-pot three-component reaction sequence leading to 2,4-disubstituted benzodiazepines.

Multicomponent reactions (MCRs) have been widely studied for the synthesis of complex molecules. The use of a fluorine component as the limiting agent to stop the MCRs is a straightforward strategy to improve the final purification: for example, the condensed products could be recovered from the reaction mixture by using fluorine solid phase extraction (F-SPE). In addition, the fluorine could be used in a further step for compound's derivatization to build elaborated multi-functionalized scaffolds.

The Ugi reaction is one of the most famous examples of MCRs. This reaction consists in mixing acid 108, aldehyde 109, isocyanide 110 and aniline 111, and leads to pseudopeptidic moieties 112 . In this context, Zhang et al. [50] reported a two-step synthesis of benzodiazepinones $\mathbf{1 1 3}$ as illustrated in Scheme 20. The protocol occurs through an Ugi reaction under MW-irradiation, followed by a cyclization in acidic media, which also proceeds under MW-irradiation. Final products are obtained in approximately $70 \%$ yield (two steps, Scheme 20 ). 


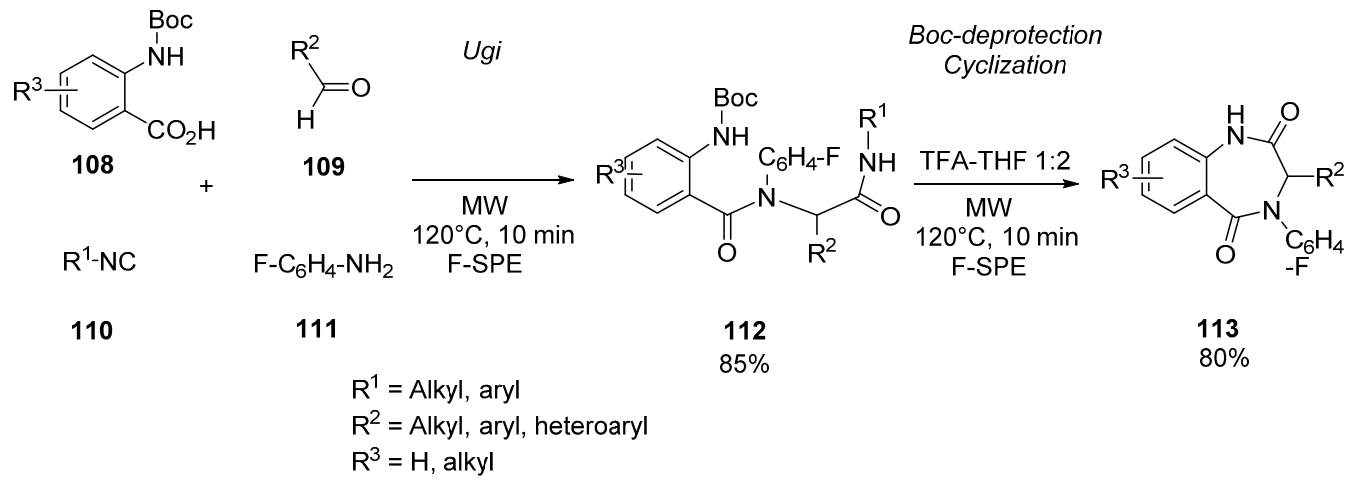

Scheme 20. Two step synthesis of benzodiazepinones via an Ugi 4-components reaction and intramolecular cyclization.

Moreover, Wang et al. [51] reported another green chemistry procedure affording benzo[f]azulen-1-one derivatives 117. This reaction is achieved by reacting benzene-1,2-diamines 115, tetronic acid 116, and various aldehydes 114 in aqueous media, under MW-irradiation, and does not require the use of a metal catalyst (Scheme 21A). The products have been obtained within 12-15 min in good to excellent yields, and with excellent regioselectivity. Indeed, only one single regioisomer was generated when 3,4-diaminobenzoic acid and 4-chlorobenzene-1,2-diamine were employed as substrates.

A<smiles>[R]C=O</smiles>

114<smiles>[R]c1cc(N)c(N)cc1[R]</smiles>

115<smiles>O=C1COC(=O)C1</smiles>

116

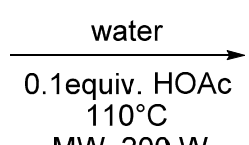

MW, $200 \mathrm{~W}$

70\%-89\%

B<smiles>[R]c1ccc(C)c(C(=O)[O-])c1[R]</smiles>

118

$\mathrm{R}^{4}=\mathrm{OMe}$,<smiles>[R]c1cc(N)c(N)cc1[R]</smiles>

115<smiles>O=C1COC(=O)C1</smiles>

116

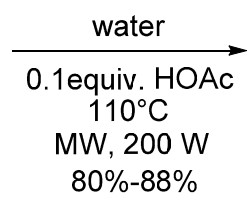<smiles>[Y20]Cc1cc2c(cc1[R])NC([R])C1=C(COC1=O)N2</smiles>

11740 examples<smiles>[R]c1cc2c(cc1[R])N1C(=O)c3c(ccc([R1])c3[R])C1C1=C(COC1=O)N2</smiles>

119, 8 examples

Scheme 21. Synthesis of benzo[f]azulen-1-ones and isoindole-fused furo[1,4]diazepines in aqueous media.

To extend the scope of this reaction, functionalized 2-formylbenzoïc acid derivatives $\mathbf{1 1 8}$ have been mixed with diamines 115 and tetronic acid (116) (Scheme 21B). In this case, the authors observed formation of pentacyclic isoindole-fused furo[1,4]diazepines 119. The unprecedented regioselective reaction occurred in excellent yields (up to $81 \%$ ) and in shortened reaction times (less than $25 \mathrm{~min}$ ).

To summarize, this green chemistry procedure displaying several attractive characteristics, such as the use of water as solvent, concise conditions, short reaction time, easy work-up, and reduced side-products formation; overall, this synthesis proceeds without strong acidic and/or metal as catalysts.

The groups of Fujii and Ohno from Kyoto University have developed a $\mathrm{Cu}(\mathrm{I})$-catalysed domino three-component coupling/indole formation/ $\mathrm{N}$-arylation cascade for the synthesis of indole-fused 1,4-diazepines 122 (Scheme 22) [52]. The first step consists on a Mannich-type reaction involving 2-ethynylanilines 120, $\mathrm{O}$-bromobenzylamines 121, and paraformaldehyde; in the next steps, 
the indole ring is cyclized, and the subsequent mesyl deprotection followed by the $\mathrm{N}$-arylation leads to the expected compounds (Scheme 23). In addition to the fused benzodiazepines, 1,4-diazepines fused with a pyridine or thiophene have been synthesized through the same protocol.

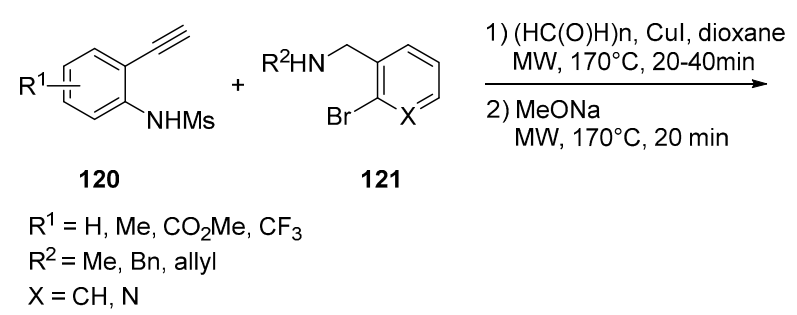

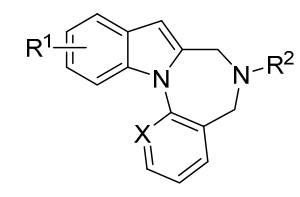

122, 8 examples $(23-85 \%)$

Scheme 22. $\mathrm{Cu}(\mathrm{I})$-catalysed domino three-component reaction leading to indole-fused 1,4-diazepines.<smiles>C#Cc1ccccc1NP</smiles><smiles>[Y]Cc1ccc(CCNCCO)cc1[X]</smiles><smiles></smiles><smiles>[R]N1Cc2ccccc2-n2c(cc3ccccc32)C1</smiles>

Scheme 23. Mechanistic study of the indole-fused 1,4-diazepine synthesis reported by Fujii and Ohno [52].

The pyrrolo[1,4]benzodiazepine-2,5-dione scaffold is also relevant in terms of pharmacological activity, as underlined by molecules such as asterrelenin (123), raspalin 3 (124) or a DNA binding fused compound 125 (Figure 8).

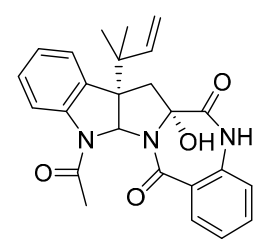

123, Asterrelenin Alkaloid from Aspergillus terreus

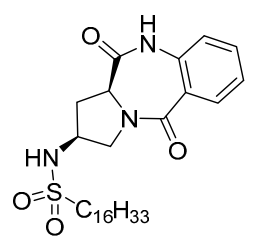

124, Raspalin 3 Thioesterase inhibitor<smiles>COc1cc(/C=C/C(=O)c2ccccc2O)ccc1OCCCOc1cc2c(cc1OC)C(=O)N1CCC[C@]1(C)C2=O</smiles>

125

DNA binding agent (anti cancer)

Figure 8. Relevant examples of bioactive pyrrolo[1,4]benzodiazepine-2,5-diones.

A very elegant stereoselective synthesis of pyrrolo[1,4]benzodiazepine-2,5-diones has been recently reported by Rodriguez's group [53] (Scheme 24). This procedure is based on a reduction-double cyclization sequence of a 1,3-ketonamide motive 126: the pyrrolidine intermediate $\mathbf{1 2 7}$ is obtained with a remarkable degree of optical purity (diastereomeric ratio (dr) 15:1) using a mixture of activated zinc in acetic acid as diastereoselective reductive agent. In the next step, the benzodiazepinone synthesis occurs through an intramolecular MW-activated lactamization. Even if the conversion rates remain modest (around 50\%), the required final compounds $\mathbf{1 2 8}$ are isolated with a good enantiomeric excess ( $86 \%$ ee). 


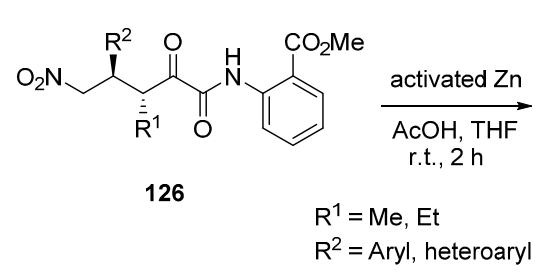

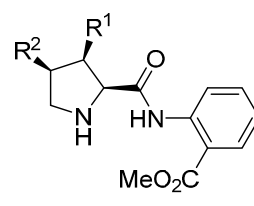

127

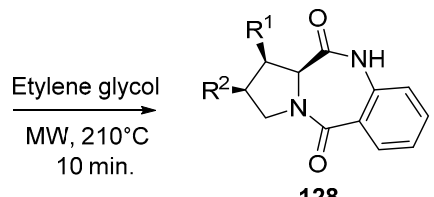

128

Scheme 24. Benzodiazepinone synthesis through a reduction-double cyclization sequence of 1,3-ketonamides.

Seven-Membered Heterocycles with Two Distinct Heteroatoms

Benzothiazepines, Benzothiepines and Their Derivatives

Several dibenzothiazepine derivatives have been marketed for their therapeutic uses. In this class of compounds, the two leading drugs are clotiapine (129), an anti-psychotic agent, and quetiapine fumarate (130), which is used in the treatment of central nervous system disorders (Figure 9) [54]. Another compound of interest is F15845 (131); this benzoxathiepine is a blocker of persistent sodium levels and is active in vivo to prevent ischemia and angina [55].

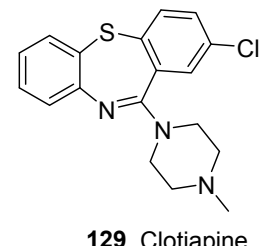

anti-psychotic

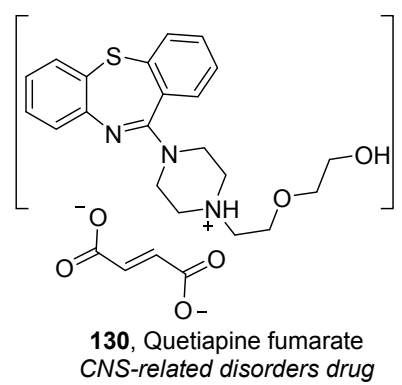

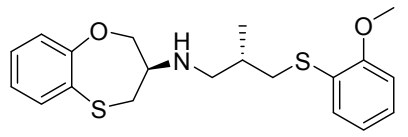

131, F15845

Cardioprotective agent

Figure 9. Relevant examples of bioactive dibenzothiazepines.

Different strategies have been used to synthesize dibenzothiazepines. For example, the ring closure metathesis (RCM), which is one of the most popular methodologies leading to heterocycles, has been used by Yadav and co-workers [56] for the preparation of series of seven-membered, benzo-fused dibenzothiazepines and dibenzoxathiepine (Scheme 25).

In this strategy, a conventional RCM procedure, using Grubb's II catalyst, afforded 2,5-dihydro-1,5-benzothazepine 133 in moderate yields (60\%) and good regioselectivity, although the reaction was very slow (approximately $24 \mathrm{~h}$ ). Conversely, the synthesis of the vinyl sulfide and sulfoxide analogs (4,5-dihydro-1,5-benzothazepines 136 and 140), does not occur under conventional heating, and requires a MW-activation and a larger amount of catalysts.

In addition, using mercaptophenol (135) as starting material led to $2 \mathrm{H}-1,5$-benzoxathiepine 137 under MW irradiation in good yields (62\%). However, using this sulfoxide, and despite the use of harsh MW-assisted conditions, including high temperatures, long reaction times and large amount of Grubb's II catalyst, the authors were unable to synthesize the sulfoxide analog of compound 139.

Saha et al. [57] have reported a two-step MW-assisted synthesis of a series of dihydrodibenzo[ $[f, f][1,4]$-thiazepine-11-carboxamides (Scheme 26). The cyclisation step consists on a reaction between aminothiophenols 141 and $o$-chlorobenzaldehydes 142, leading to the intermediates 143. In the first step of this synthesis, amine and aldehydes react together, and afford the imine intermediate I1 (Scheme 27) according to a conventional base-catalyzed mechanism; in the second step, the seven-membered benzothiazepines $\mathbf{1 4 3}$ are cyclized through a copper assisted C-S bond formation. Under MW-activation, this reaction requires $10 \mathrm{~mol} \%$ of catalyst and $20 \mathrm{~mol} \%$ of L-proline as ligand and occurs in $15 \mathrm{~min}$. 
Conventional heating<smiles>CN(CCO)c1ccccc1S(=O)(=O)O</smiles>

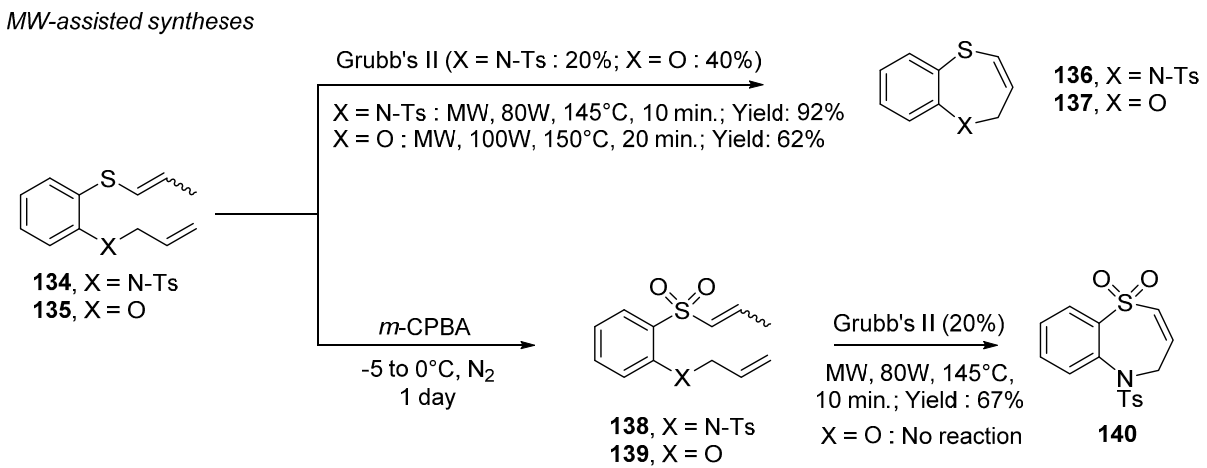

Scheme 25. MW-assisted RCM affording benzo-fused dibenzothiazepines and dibenzoxathiepines.

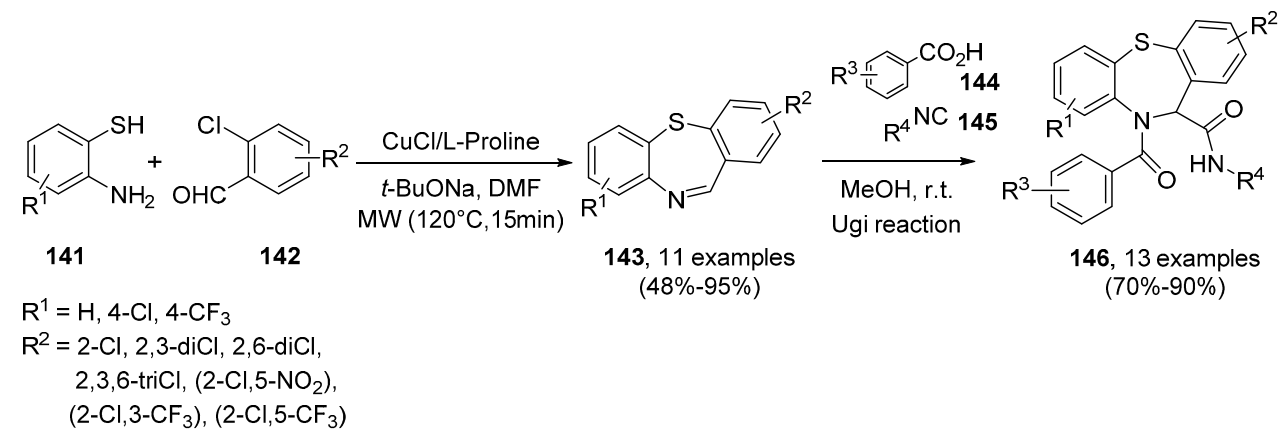

Scheme 26. Copper-assisted C-S bond formation leading to series of dihydrodibenzo[ $[b, f][1,4]$ thiazepine-11-carboxamides.

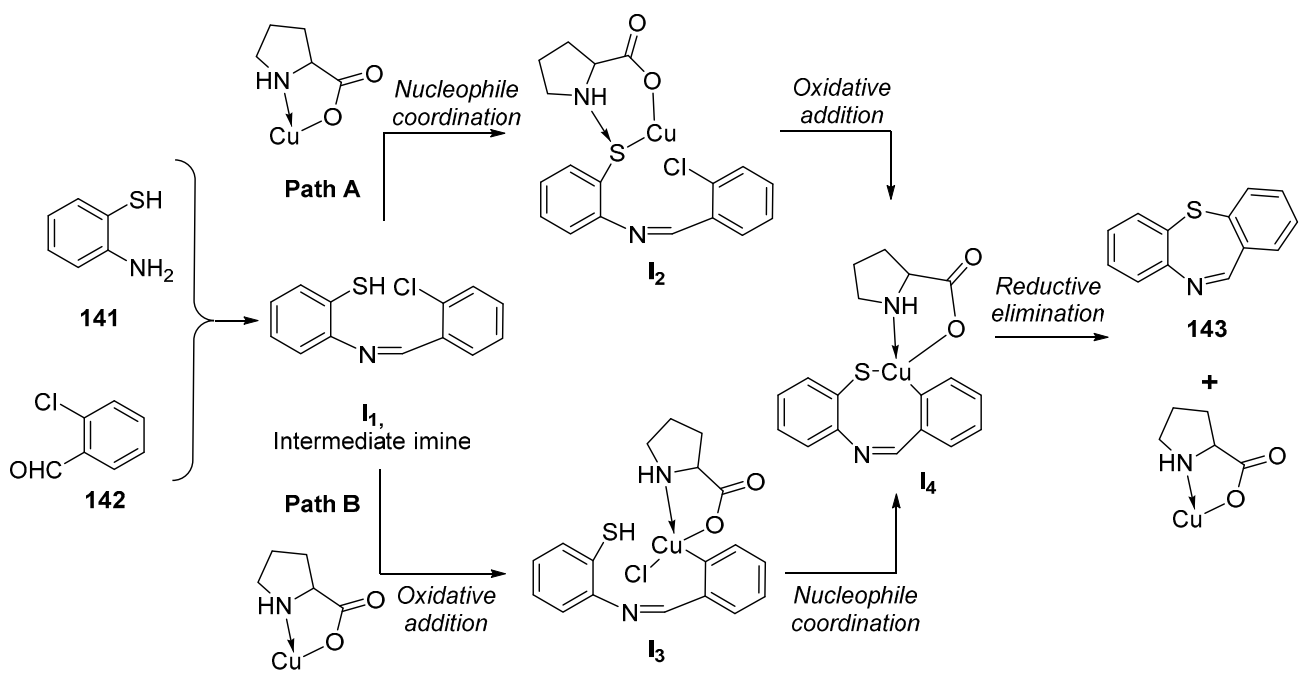

Scheme 27. Mechanistic study of the C-S bond formation reported by Saha et al. [57].

The mechanistic study of the C-S bond formation revealed two possible catalytic pathways. In the first one (Scheme 27, Path $\mathrm{A}$ ), the coordination of the proline ligated $\mathrm{Cu}(\mathrm{I})$ complex to 
deprotonated thiolate (nucleophilic coordination, intermediate $\mathbf{I}_{\mathbf{2}}$ ) precedes the oxidative addition. Conversely, in the second pathway (Scheme 27, Path B), the coordination to the thiolate occurs after the oxidative addition of the copper complex to the halogenobenzene (intermediate $\mathbf{I}_{3}$ ).

The second step of the benzothiazepine carboxamides synthesis consists on an Ugi multi-components reaction involving the macrocycles 143, aliphatic and/or aromatic carboxylic acids 144 and nitriles 145. These Ugi reactions are managed under conventional activation, and afforded the various dihydrodibenzo[ $[b, f][1,4]$-thiazepine-11-carboxamide derivatives 146 in high yields.

Tu et al. [58] have reported a straightforward strategy for the synthesis of benzo[e][1,4]thiazepin$2(1 H, 3 H, 5 H)$-ones 150 , via a MW-assisted multi-component reaction in aqueous media, yielding to the expected molecules with excellent conversion rates (89\%-94\%) and shortened reaction times (7-10 $\mathrm{min}$ ). This green strategy consists on a three-component reaction involving various aromatic amines 147, series of aldehydes 148, and mercaptoacetic acid (149, Scheme 28).

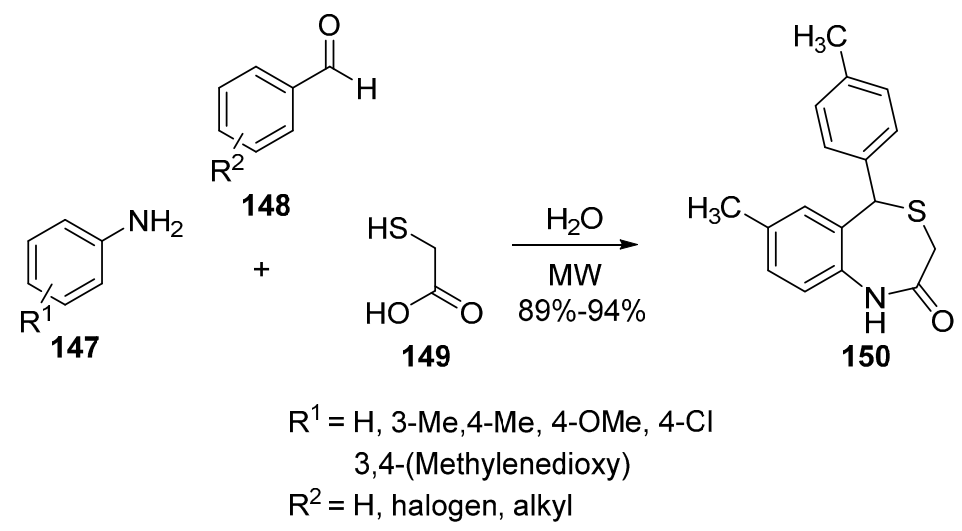

Scheme 28. MW-assisted three-component reaction in water affording benzo[ $e][1,4]$ thiazepin$2(1 H, 3 H, 5 H)$-ones.

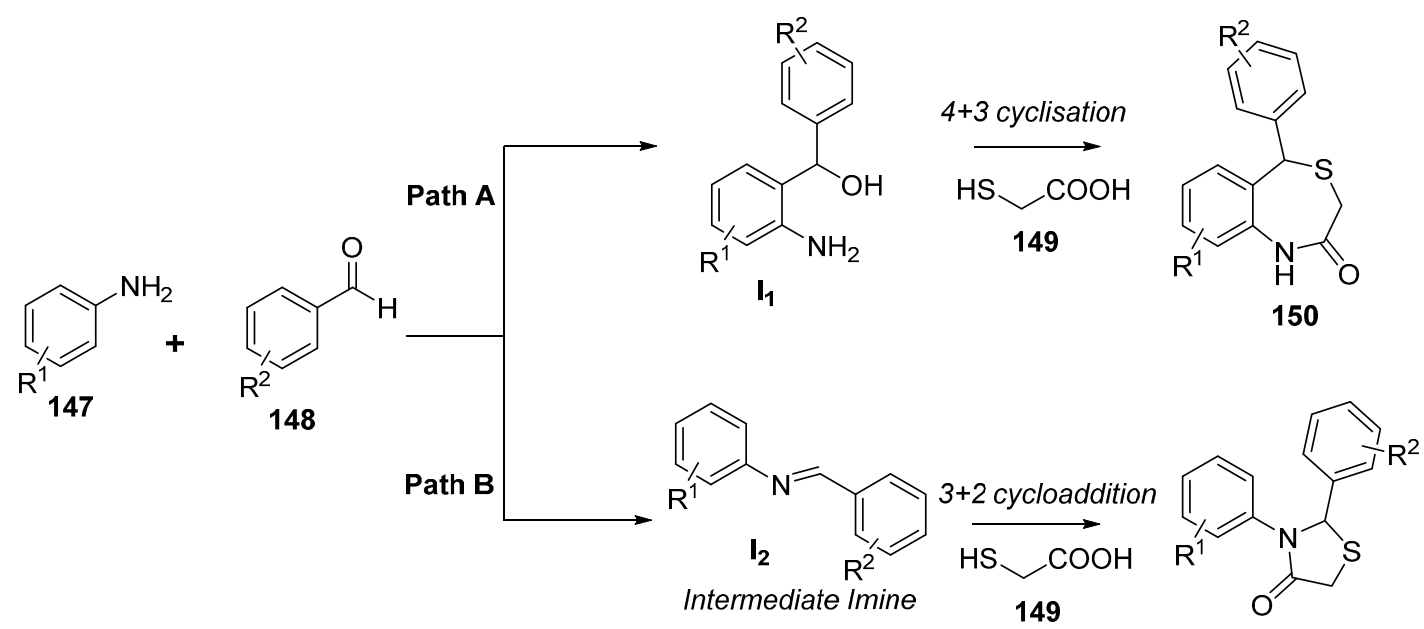

Scheme 29. Mechanistic study of the benzo[e][1,4]thiazepin-2(1H,3H,5H)-ones syntheses reported by Tu et al. [58].

Interestingly, the regioselectivity of this macrocyclisation depends on the nature of the aldehyde's substituent (group $\mathrm{R}^{2}$ on compounds 148). Indeed, electron-donating groups act in favour of an aromatic electrophile substitution (Scheme 29, Path A), resulting in the formation of intermediate $\mathbf{I}_{\mathbf{1}}$. In the second step, this intermediate $\mathbf{I}_{\mathbf{1}}$ undergoes a $[4+3]$ cyclisation with mercaptoacetic acid, affording the seven-membered lactam 150. Conversely, electron-withdrawing groups lead to a conventional nucleophilic attack of the carbonyl, resulting in the formation of the intermediate 
imine $\mathbf{I}_{\mathbf{2}}$, whose [3 + 2] cycloaddition with mercaptoacetic acid gives the corresponding thiazolidinone (Scheme 29, Path B). Nevertheless, the presence of a potent electron-donating group on the aromatic amine can overcome the chemoselectivity, and subsequently restore the Path A, and the synthesis of the seven-membered ring.

A straightforward solvent-free MW-assisted multicomponent synthesis of 1,4-thiazepines fused with carbazoles, pyrazoles or isoxazoles has been reported by Shi et al. [59]. This strategy illustrates the potency of the multicomponent reactions as a tool for the "diversity-oriented syntheses". These approaches not only allow the quick and efficient synthesis of heterocycle libraries, but also reduce concomitantly their environmental impact. Practically, the 1,4-thiazepines have been synthesized through MW-assisted condensation of aldehydes, mercaptoacetic acid and series of heteroaromatic amines. These syntheses were carried out in absence of solvent at $120^{\circ} \mathrm{C}$, and were completed in less than $10 \mathrm{~min}$ (Scheme 30).
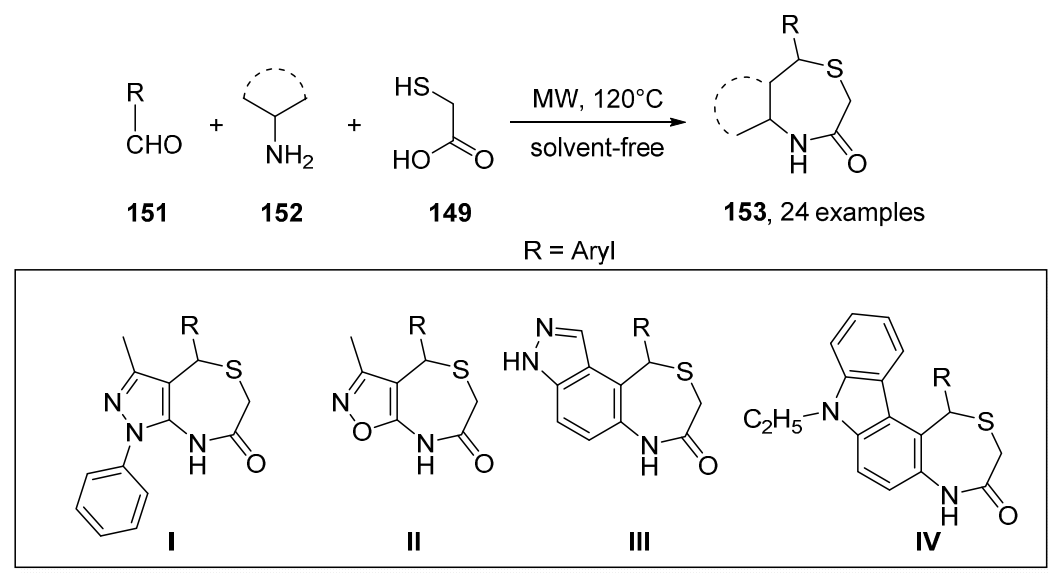

Scheme 30. Solvent-free multicomponent reaction affording 1,4-thiazepines.

Among them, several derivatives exhibited in preliminary biological assays anti-oxidant and/or anti-proliferative activities. Indeed, at the dose of $2 \mathrm{mg} / \mathrm{mL}$, these compounds reduce the HCT 116 cancer cells viability by 50\%, without affecting healthy lymphocytes viability [59].

Oxazepines and Their Derivatives

The oxazepine core is a seven-membered heterocycle with one atom of nitrogen and one atom of oxygen. This scaffold is also used to design potent therapeutic agents, as illustrated by Loxapin, a marketed anti-psychotic drug; in addition, several oxazepines have been designed as potent kinase inhibitors (Figure 10) [60-62].
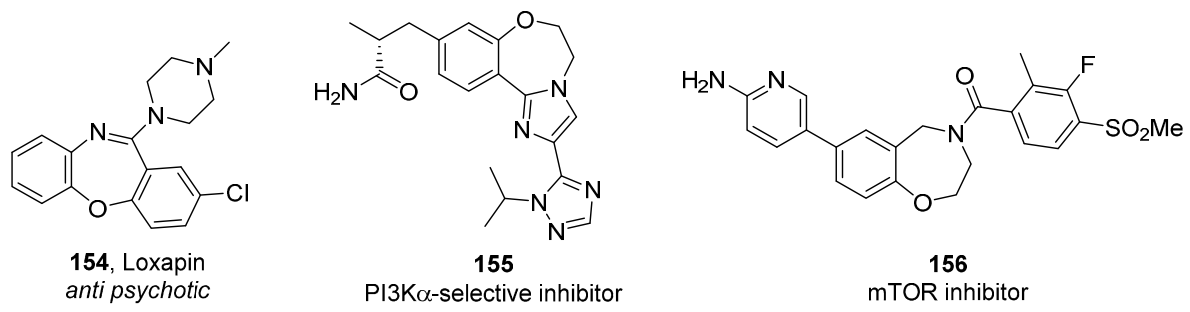

Figure 10. Examples of representative oxazepines.

An elegant synthesis of unprecedented triazolo-fused benzoxazepinones 161 (Scheme 31A) and benzoxazepines 166 (Scheme 31B), which combines a conventional 3-component Passerini reaction with a MW-assisted Hüisgen azide-alkyne [1,3]-dipolar cycloaddition has been reported by Basso and co-workers [63]. 

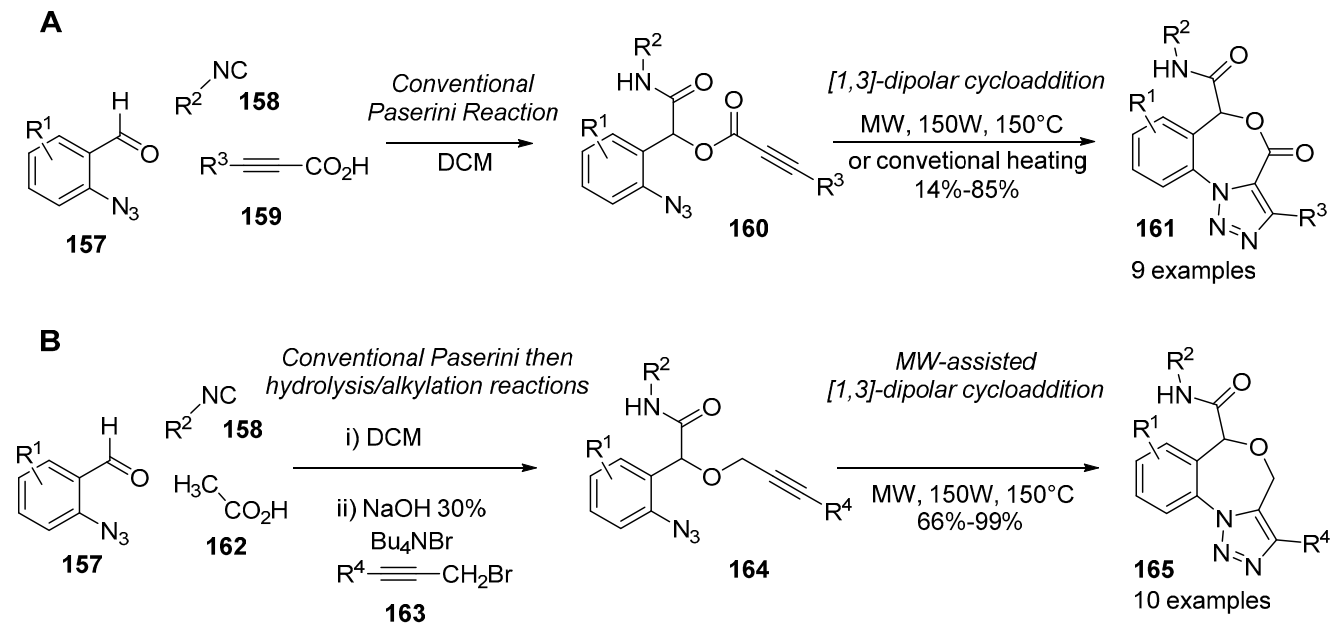

$\mathrm{R}^{1}=\mathrm{H}, 3-\mathrm{Cl}, 5-\mathrm{Me}$

$\mathrm{R}^{2}=\mathrm{Cy}, \mathrm{BBu}, \mathrm{CO}_{2} \mathrm{Et}, 4-\mathrm{OBnC}_{6} \mathrm{H}_{4}$

$\mathrm{R}^{3}=\mathrm{H}, \mathrm{TMS}, \mathrm{Pr}, \mathrm{C}_{6} \mathrm{H}_{5}$

$\mathrm{R}^{4}=\mathrm{H}, \mathrm{Pr}, \mathrm{C}_{6} \mathrm{H}_{5}, 3-\mathrm{OMeC}_{6} \mathrm{H}_{4}$

Scheme 31. Synthetic route to triazolo-fused benzoxazepinones and benzoxazepines via successive Passerini reaction and [1,3]-dipolar cycloaddition.

The dipolar cycloaddition leading to the final benzoxazepinones 161 could be performed either under conventional heating or under MW-irradiation. Interestingly, the conventional heating is very detrimental in terms of reaction speed (several days are required for a complete conversion, due to the poor reactivity of the alkyne group), but generally leads to cleaner products than the MW-assisted reaction. Indeed, when using the MW-assisted procedure, the authors failed to isolate the pure final benzoxazepinones 161. In marked contrast, the cycloaddition leading to the final benzoxazepines 165 is easily achieved by means of MW-irradiation.

Also, a MW-assisted green synthesis of triazolobenzoxazepines has been suggested by Sen and co-workers [64]. This one-pot reaction is based on a Sonogashira azide-alkyne cycloaddition, and was carried out using $\mathrm{Cu}$ (Phen) $\left(\mathrm{PPh}_{3}\right) \mathrm{Br}$ as catalyst (Scheme 32). Overall, this synthesis is performed on a solid support, basic alumina, which has the ability to absorb organic compounds and transmit microwave irradiation without adsorbing or restricting it. In this context, the cyclisation occurs with only $2.5 \%$ of catalysts and affords in shortened reaction time the expected products in good yields (up to 60\%). Moreover, the solid support can be re-used after washing three times without any changes in conversion rates. This green protocol of cyclization is compatible with a huge variety of scaffolds and can be used to build other heterocycles such as triazolobenzodiazepines or triazolo- benzoxazines.

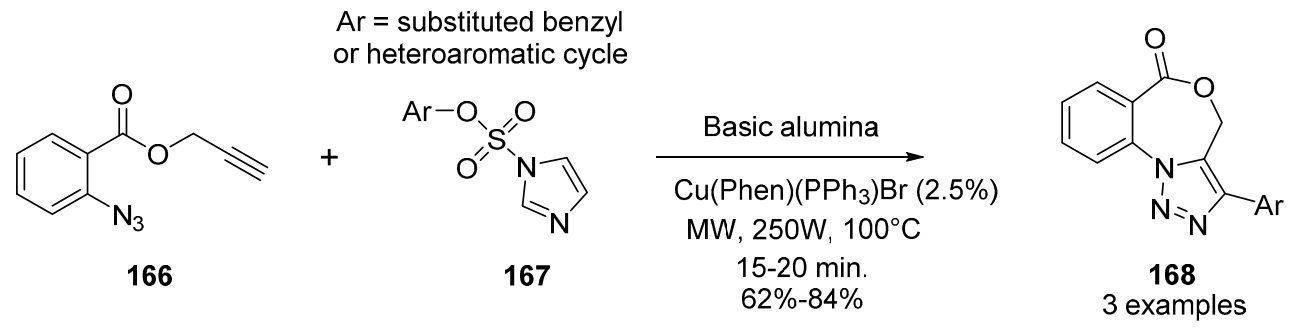

Scheme 32. One-pot, green synthesis of triazolobenzoxazepines through Sonogashira azide-alkyne cycloadditions.

The MW-assisted synthesis of highly functionalized dibenz[ $f, f][1,4]$ oxazepin-11(10H)-ones 175 and $\mathbf{1 7 6}$ has been also reported by Xing et al. [65] (Scheme 33). The oxazepine derivatives were 
obtained via a one-pot two-reaction sequence, which combines an Ugi reaction and an intramolecular $o$-arylation, in good to excellent yields.

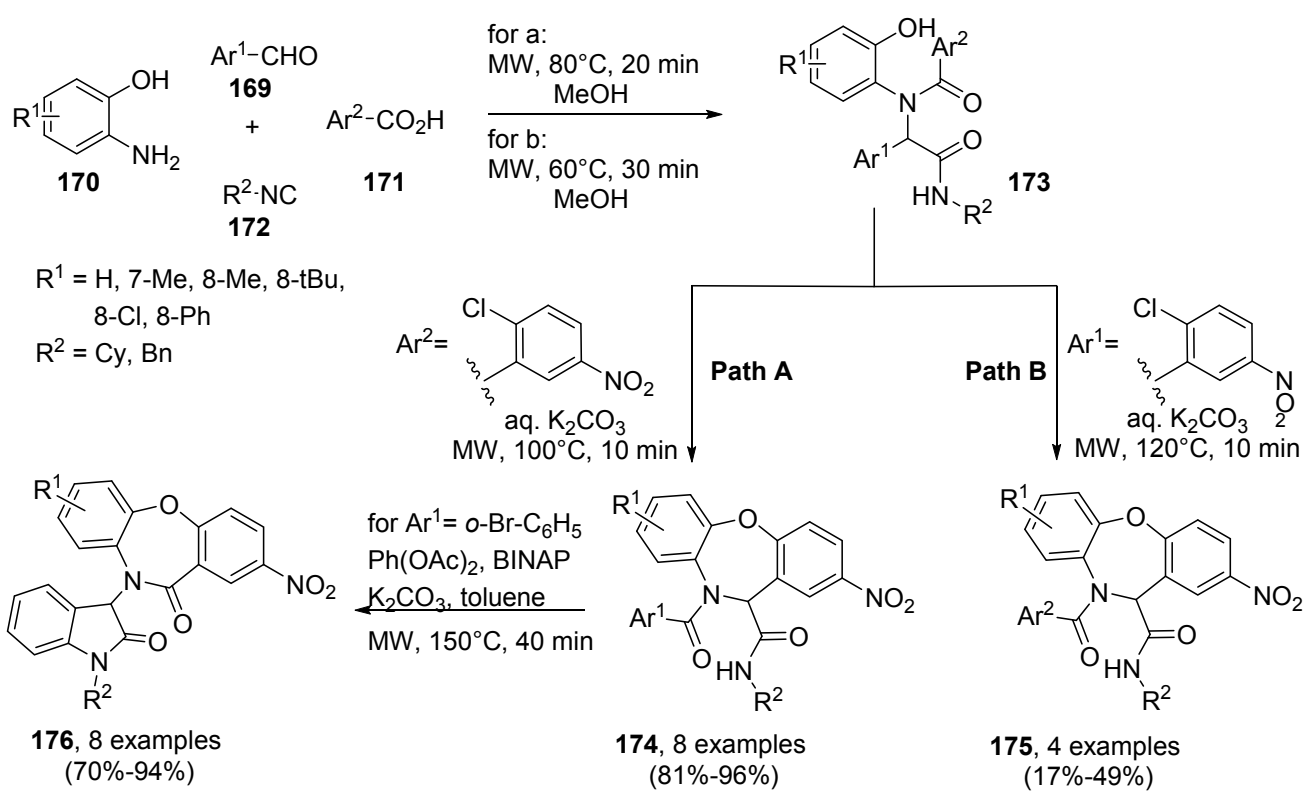

Scheme 33. Oxazepines synthesis via Ugi 4-component reaction and intramolecular $O$-arylation.

\subsubsection{Seven-Membered Heterocycles with Three Heteroatoms}

\section{Benzotriazepines and Their Fused Analogues}

Benzotriazepine derivatives are commonly used for their antibacterial, antiviral, anti-protozoan (plasmodium) and psychotropic activities; series of benzotriazepines have been also designed as potential anti-cancer or anti-viral agents [66-69] (Figure 11).

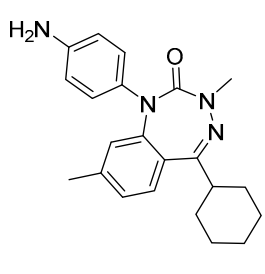

177
$\mathrm{PTH}_{1} \mathrm{R}$ antagonist

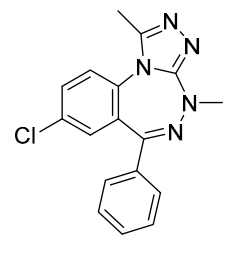

178 , BET transcriptional co-
regulators inhibitor

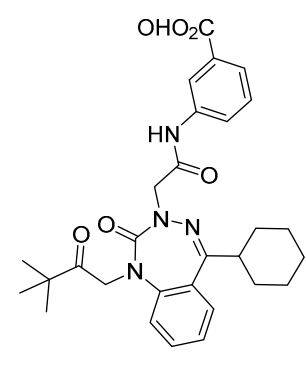

179,
$\mathrm{CCK}_{2}$ receptor antagonist

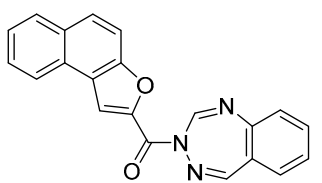

180 ,

Anti-bacterial agent

Figure 11. Representative examples of bioactive benzotriazepines.

In addition, some of them have been also used as acaricidal, herbicidal and insecticidal agents. In this context, Dong et al. [70] reported an interesting synthesis of benzotriazepines based on a palladium-catalysed cyclization of aryl isocyanates $\mathbf{1 8 1}$ and phenyl hydrazones under MW-irradiation (Scheme 34). Taking advantage of the difference between iodine and bromine in term of reactivity towards the $\operatorname{Pd}(0)$ oxidative addition, the authors have reported a divergent synthesis of benzotriazepines 183 and 1-arylamide- $1 H$-indazoles 185. Indeed, bromophenyl hydrazones 182 afforded exclusively the benzotriazepines derivatives 183 with $5 \mathrm{~mol} \%$ of $\mathrm{Pd}(\mathrm{OAc})_{2}$ and $10 \mathrm{~mol} \%$ of $\mathrm{PPh}_{3}$ in 20 min and under MW-activation with high conversion rates, whereas in the same conditions 
iodine hydrazones 184 lead to the 1 -arylamide- $1 H$-indazole series $\mathbf{1 8 5}$. It is noteworthy that in this latter case, the use of bulky derivatives as starting material lead to a mixture of benzotriazepines and indazoles.

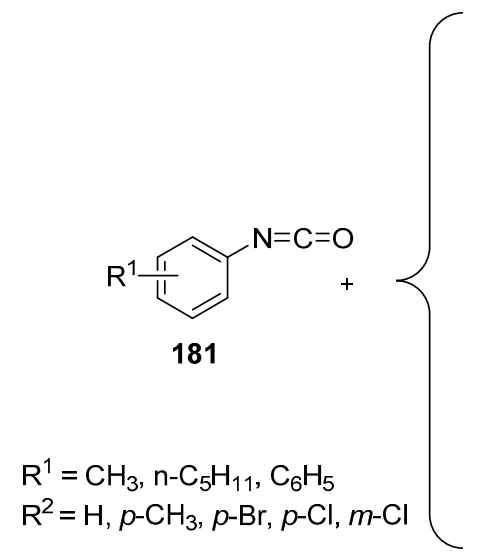<smiles>[R2]C(=NN)c1ccccc1Br</smiles>

$$
\begin{gathered}
\underset{\mathrm{Pd}(\mathrm{OAc})_{2}(5 \mathrm{~mol} \%)}{\mathrm{PPh}_{3}(20 \mathrm{~mol} \%)} \\
\underset{\mathrm{K}_{2} \mathrm{CO}_{3}, \mathrm{CH}_{3} \mathrm{CN}}{\longrightarrow} \\
\mathrm{MW}, 80^{\circ} \mathrm{C}, 20 \mathrm{~min} \\
14 \%-82 \%
\end{gathered}
$$<smiles>[R]/C(=N\N)c1ccccc1I</smiles>

184

$\mathrm{Pd}(\mathrm{OAc})_{2}(5 \mathrm{~mol} \%)$ $\mathrm{PPh}_{3}(20 \mathrm{~mol} \%)$

$\mathrm{K}_{2} \mathrm{CO}_{3}, \mathrm{CH}_{3} \mathrm{CN}$ $\mathrm{MW}, 80^{\circ} \mathrm{C}, 20 \mathrm{~min}$ $9 \%-89 \%$<smiles>[R]C1=NNC(=O)N(c2ccccc2)c2ccccc21</smiles>

183, 14 examples<smiles>[R]c1cccc(NC(=O)n2nc([R])c3ccccc32)c1</smiles>

185, 14 examples

Scheme 34. Synthesis of benzotriazepines and indazoles.

The authors hypothesized the mechanism outlined in Scheme 35. Indeed, they postulated that the regioselectivity of the reaction is driven by the intramolecular palladation during the second phase of the reaction, and depends: (i) on the nature of the halogen; and (ii) on the steric hindrance of the aryl hydrazones.

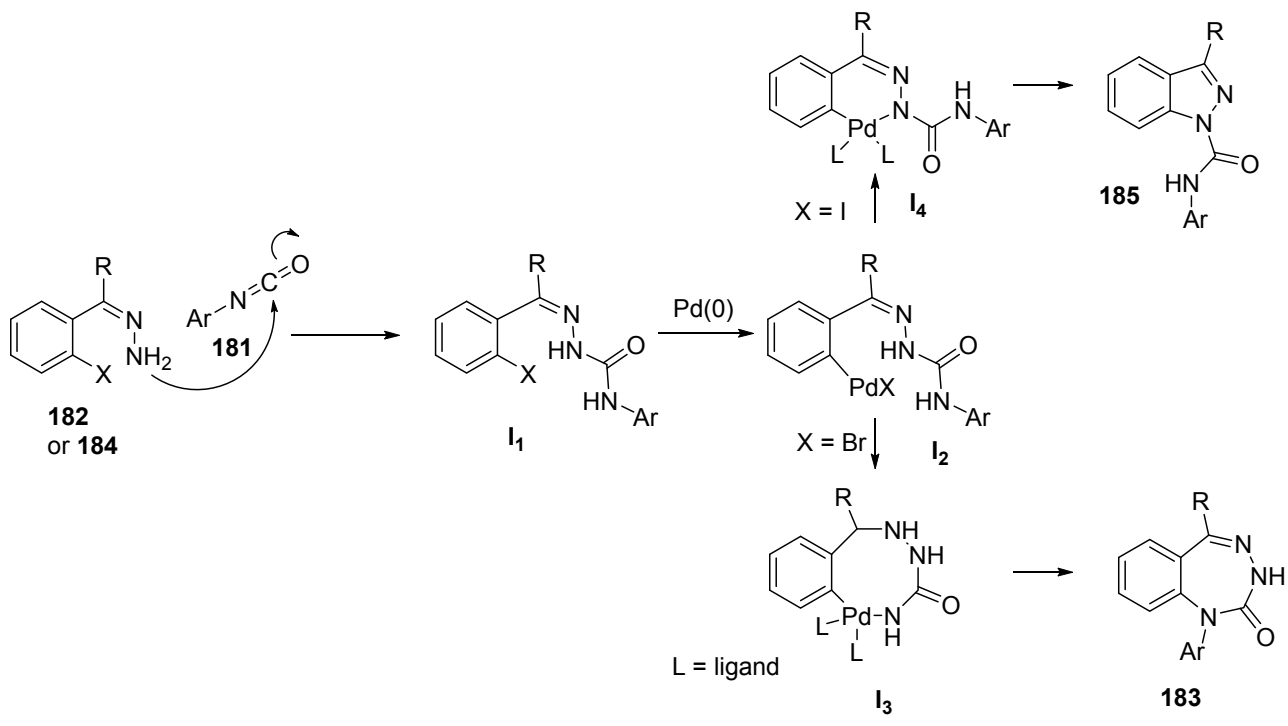

Scheme 35. Mechanistic study of the benzotriazepines and indazoles synthesis reported Dong et al. [70].

Gupta et al. [71] have reported a simple, efficient and green MW-assisted procedure for the synthesis of 1-substituted-8-aryl-3-alkyl/aryl-4H-pyrazolo[4,5-f][1,2,4]triazolo[4,3-b][1,2,4]triazepines 189 . This reaction occurs on a solid support (basic alumina), using DMF as an energy transfer agent, and $p-\mathrm{TsOH}$ as catalyst. The products have been obtained in good yields $(62 \%-76 \%)$ with high purity, in 4 to $25 \mathrm{~min}$ (Scheme 36). Lower conversion rates were obtained when conventional heating was used. 
<smiles>[R]c1nnc(N)n1N</smiles>

186<smiles>[R]c1nn([R3])c(Cl)c1CC</smiles>

187

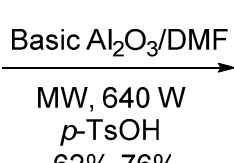

$62 \%-76 \%$

$$
\begin{aligned}
& \mathrm{R}^{1}=\mathrm{C}_{6} \mathrm{H}_{5}, 4-\mathrm{ClC}_{6} \mathrm{H}_{4}, \mathrm{Bn},\left(4-\mathrm{NO}_{2}\right) \mathrm{C}_{6} \mathrm{H}_{4} \\
& \mathrm{R}^{2}=\mathrm{Me}, \mathrm{C}_{6} \mathrm{H}_{5}, 4-\mathrm{BrC}_{6} \mathrm{H}_{4},\left(4-\mathrm{NO}_{2}\right) \mathrm{C}_{6} \mathrm{H}_{4} \\
& \mathrm{R}^{3}=\mathrm{H}, \mathrm{C}_{6} \mathrm{H}_{5}
\end{aligned}
$$<smiles>[R]C1=NNC2Nn3c([R])nnc3N=CC12</smiles>

188

10 examples

Scheme 36. Green procedure for the synthesis of fused triazepines on a solid support.

In a similar way, these authors [72] also reported the synthesis of the 1,2,4-triazepine analogs 192 according to an original green procedure involving an ionic liquid (IL) as solvent, and using either MW-activation or oil-bath heating. The products were isolated in good to moderate yields, and in high degrees of purity (Scheme 37). Moreover, the ionic liquid was found to be recyclable for at least three consecutive reaction cycles, making the process cost-effective and economic. In a preliminary anti-fungal assay, some compounds showed high potencies against Aspergillus niger and Pencillium notatum, Aspergillus flavus and Rhizopus.

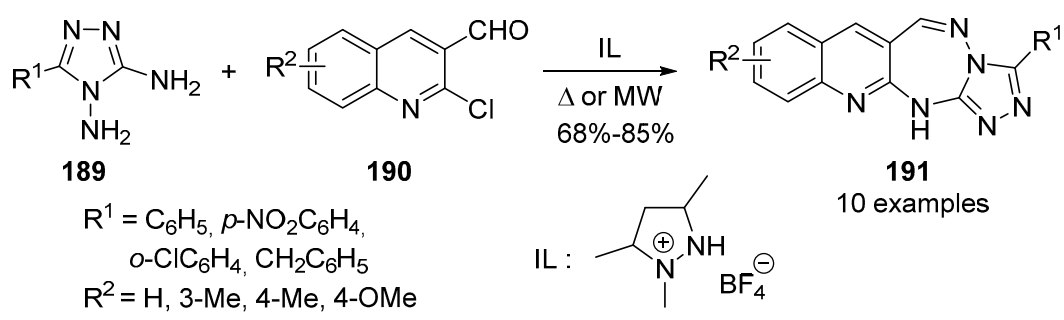

Scheme 37. Green procedure for 1,2,4-triazepine synthesis in ionic liquid as solvent.

\section{Thiadiazepines and Benzothiadiazepines}

A solvent-free and MW-assisted procedure has also been developed for the synthesis of potentially bioactive thiadiazepines 194. This procedure involved the reaction of 1-amino-2-mercapto-5-substituted triazoles 192 and substituted chalcones 193 using basic alumina as solid support (Scheme 38). Interestingly, this reaction requires longer reaction times and exhibits lower conversion rates when performed in solution phase [73]. Recently, $p$ - $\mathrm{TsOH}$ has been also reported as a suitable catalyst for this transformation under MW-irradiation [74].

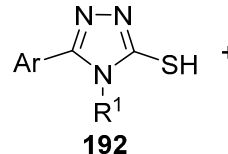<smiles></smiles>
$\underset{\text { MW, } 1-2 \mathrm{~min}}{\stackrel{\text { Basic Alumina }}{\longrightarrow}}$

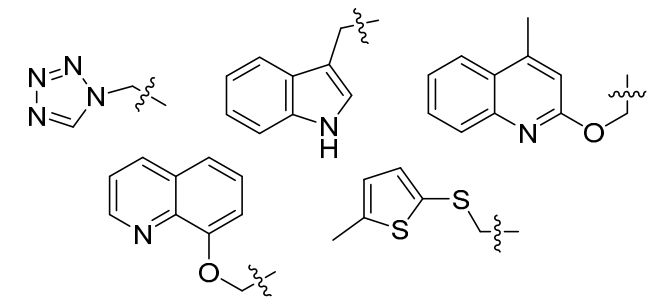

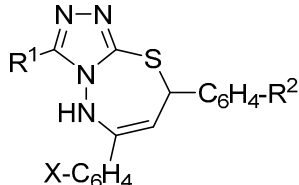

194

$90 \%-97 \%$

$\mathrm{R}^{2}=4-\mathrm{MeO}, 3,4-\mathrm{OCH}_{2} \mathrm{O}-$

$\mathrm{X}=\mathrm{H}, 4-\mathrm{Br}$

Scheme 38. Solvent free synthesis of thiadiazepines. 
To the best of our knowledge, very few MW-induced syntheses of benzothiadiazepines on solid support have been reported. In this context, the simple, efficient and green procedure highlighted by Gupta and co-workers is a remarkable exception [75]. In this study, the authors demonstrated that the reaction of 1-amino-2-mercapto-1,3,4-triazoles 195 with 5-chloro-4-formyl-1,2-pyrazoles 196 in presence of $p$ - $\mathrm{TsOH}$ and basic alumina, leads the expected highly functionalized $[1,3,4]$ thiadiazepines 197 in less than $10 \mathrm{~min}$ and with good yields (up to 62\%). The basic alumina acts as a solid support; it increases not only the sulfur atom basicity, but also provides an environment-friendly media. Lastly, $p$-TsOH converts carbonyl into a potent leaving group and therefore increases the reaction speed (Scheme 39).<smiles>[R]c1nnc(S)n1N</smiles>

195<smiles>[R]c1nn([R])c(Cl)c1CO</smiles>

196

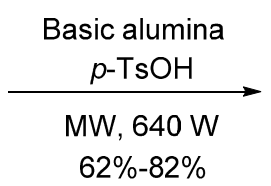

$62 \%-82 \%$<smiles>[R]c1nn([R3])c2c1C=Nn1c([R])nnc1S2</smiles>

197

$\mathrm{R}^{1}=\mathrm{Me}, \mathrm{Et}, \mathrm{Pr}, \mathrm{C}_{6} \mathrm{H}_{5}, 4-\mathrm{ClC}_{6} \mathrm{H}_{4}$, $4-\mathrm{OMeC}_{6} \mathrm{H}_{4}$ $\mathrm{R}^{2}=\mathrm{Me}, 4-\mathrm{BrC}_{6} \mathrm{H}_{4},\left(4-\mathrm{NO}_{2}\right) \mathrm{C}_{6} \mathrm{H}_{4}$ $\mathrm{R}^{3}=\mathrm{H}, \mathrm{Ph}$

Scheme 39. Green synthesis of thiadiazepines.

Lastly, Assaker and co-workers reported a green protocol and solvent free synthesis of [1,3,4]-thiadiazepines (Scheme 40) [76]. To this end, chalcones 198 were allowed to react with a series of 1-amino-2-mercapto-5-substituted triazoles 199 in presence of basic alumina and under MW-irradiation, to afford the expected 7,8-dihydro-3,7-diaryl-9-(thiopen-2-yl)-[1,2,4]triazolo[3,4- $b][1,3,4]$ thiadiazepine derivatives 200. These compounds have been obtained with high yields (up to 89\%) and short reaction times (less than $30 \mathrm{~min}$ ). By a marked contrast, a conventional heating (refluxing acetone, $\mathrm{K}_{2} \mathrm{CO}_{3}$ as base) afforded the products with moderate yields and long reaction times (more than $15 \mathrm{~h}$ ).<smiles>O=C(/C=C/Br)c1cccs1</smiles>

198<smiles>[R]c1nnc(S)n1N</smiles>

199

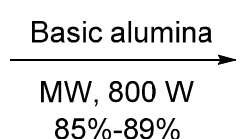
85\%-89\%

$\mathrm{Ar}=p-\mathrm{FC}_{6} \mathrm{H}_{4}, p-\mathrm{CNC}_{6} \mathrm{H}_{4}, 2$-thienyl

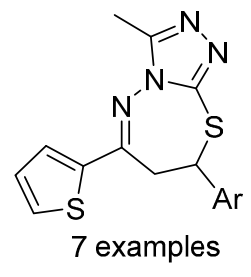

200

Scheme 40. Green synthesis and solvent free synthesis of thiadiazepines.

\subsection{Synthesis of Other Macroheterocycles}

\subsubsection{Cyclic Peptides and Pseudo-Peptides: MW-Irradiation Applied to SPPS}

The MW-irradiation procedure applied to manual or automated solid-phase peptide synthesis (SPPS) for the coupling reaction and/or for the $\mathrm{N}^{\alpha}$-deprotection, has been extensively studied and used in the last decade. Compared to conventional SPPS, this methodology results in gains on final peptide yields, especially for peptides with long sequences or peptides including "difficult" sequences (such as $\beta$-sheet type structures), combined with an increase of the crude peptide purity [77]. Moreover, the MW-activation is not detrimental in terms of optical purity: the racemization rates are usually very close when heating at the same temperature under MW-activation or when using a conventional 
heating. Recent studies have demonstrated that these improvements are reliable to the MW thermic effects rather than to the specific electromagnetic effect. Lastly, MW-assisted SPPS is compatible with several solid supports, such as polystyrene resins, PEG supports, Wang-resin, chlorotrityl resins, and rink amide resins [78-80].

In this context, MW-assisted SPPS has been applied to the macrocyclization of peptides, pseudo-peptides and peptidomimetics (peptoids, $\beta$-peptides). To this end, different cyclization strategies have been reported, among them thioether formation, lactamisation, RCM, or Glaser coupling.

For example, a series of 20-membered macrocyclic peptidomimetics has been recently synthesized using MW-irradiation for the cyclization step [81]. This MW-assisted cyclization occurs through a nucleophilic aromatic substitution $\left(\mathrm{S}_{\mathrm{N}} \mathrm{Ar}\right)$ between a cysteine and a $p$-fluoronitrobenzene derivative before the cleavage of the peptide from the resin. This cyclization is performed at $50{ }^{\circ} \mathrm{C}$ and within 10 min only (Scheme 41). This straightforward synthesis afforded the macrocyclic peptide 202 in high yield (70\%) and with high degree of purity.

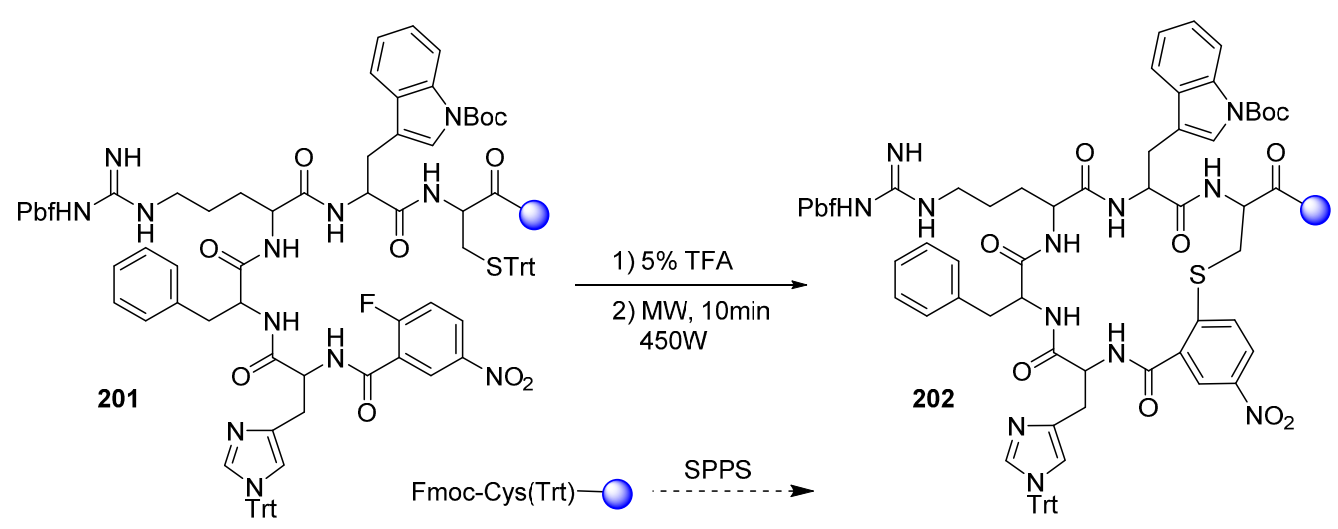

Scheme 41. MW-assisted synthesis of 20-membered cyclic peptidomimetics.

Another interesting example of peptidomimetic cyclization through a MW-assisted thioether bond formation has been recently reported by Ibrahim et al. [82]. Firstly, the $N$-acylbisbenzotriazoles 207 were obtained under classical conditions by mixing appropriate dicarboxylic acids 204 and $1 H$-benzotriazole 203 in the presence of thionyl chloride (Scheme 42). In the next step, these derivatives were converted in excellent yields into bis( $S$-acylcysteine) esters by means of a regioselective $S$-acylation of cysteine esters. The resulting pyridine dicysteine ester hydrochlorides 208, 209 were subsequently treated with $\mathrm{N}$-acylbisbenzotriazoles 207 in the presence of triethylamine under MW-irradiation for 20 min to afford the cyclic and enantiopure peptidomimetics 210 via double $N$-acylation in moderate to good yields (Scheme 42).

Some of these cyclic peptidomimetics, exhibited potent minimum inhibitory concentration (MIC) against $C$. albicans ranking between $0.0075 \mu \mathrm{g} / \mathrm{mL}$ and $0.03 \mu \mathrm{g} / \mathrm{mL}$, by comparison with the reference drug amphotericin B, which showed in the same assay a MIC $=0.35 \mu \mathrm{g} / \mathrm{mL}$. Moreover, the best hit compound is 10,000-fold more potent against K. pneumoniae than the reference compound ciprofloxacin. Conversely, in a cytotoxic assay, these molecules exhibited moderate activities against a panel of several human cancer cell lines by comparison with doxorubicin used as reference [82].

Tala and co-workers have recently reported a MW-assisted SPPS of two 7-mer peptides cyclized through a side-chain lactam bridge (Scheme 43) [83]. By a marked contrast with conventional methods leading to lactam bridged peptides, and which involve special reaction conditions, specific protecting groups, require long reaction times and lead sometimes to huge levels of side products, the process reported by these authors afforded the cyclized peptides with a high level of purity and in shortened reaction times. In addition, to simplify the purification, the cyclization step is performed while the peptide is still bound to the resin. 


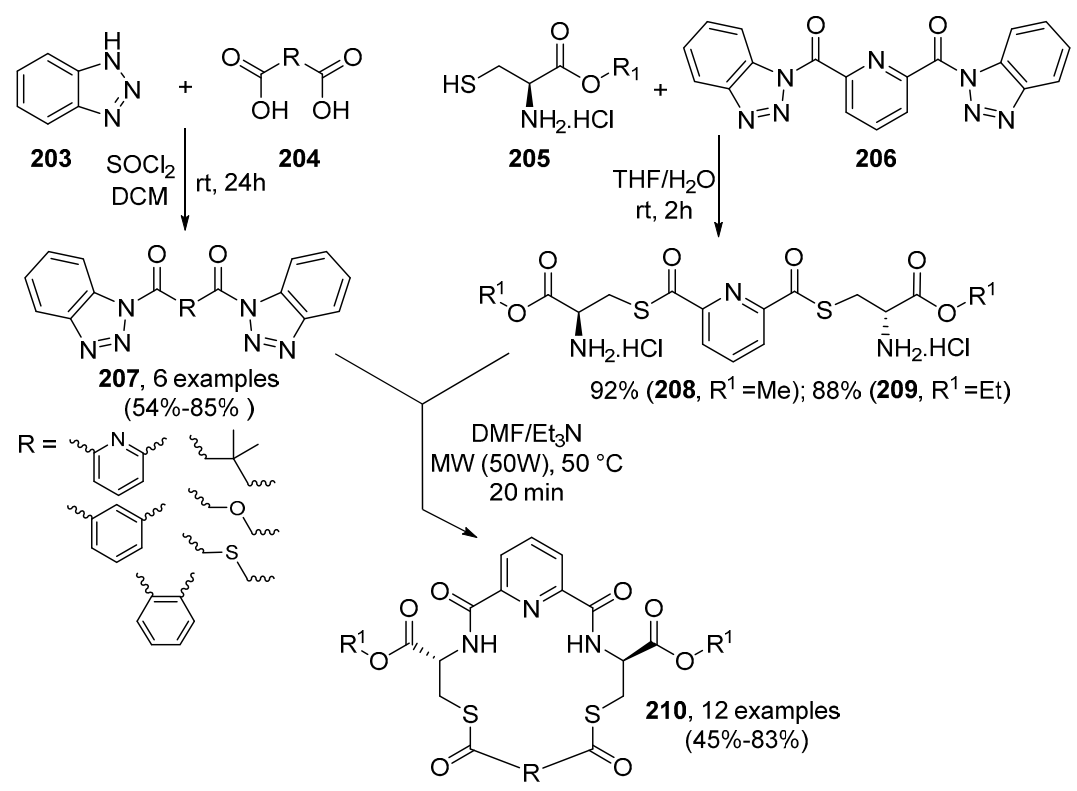

Scheme 42. Example of peptidomimetic cyclization through a MW-assisted thioester bond formation.

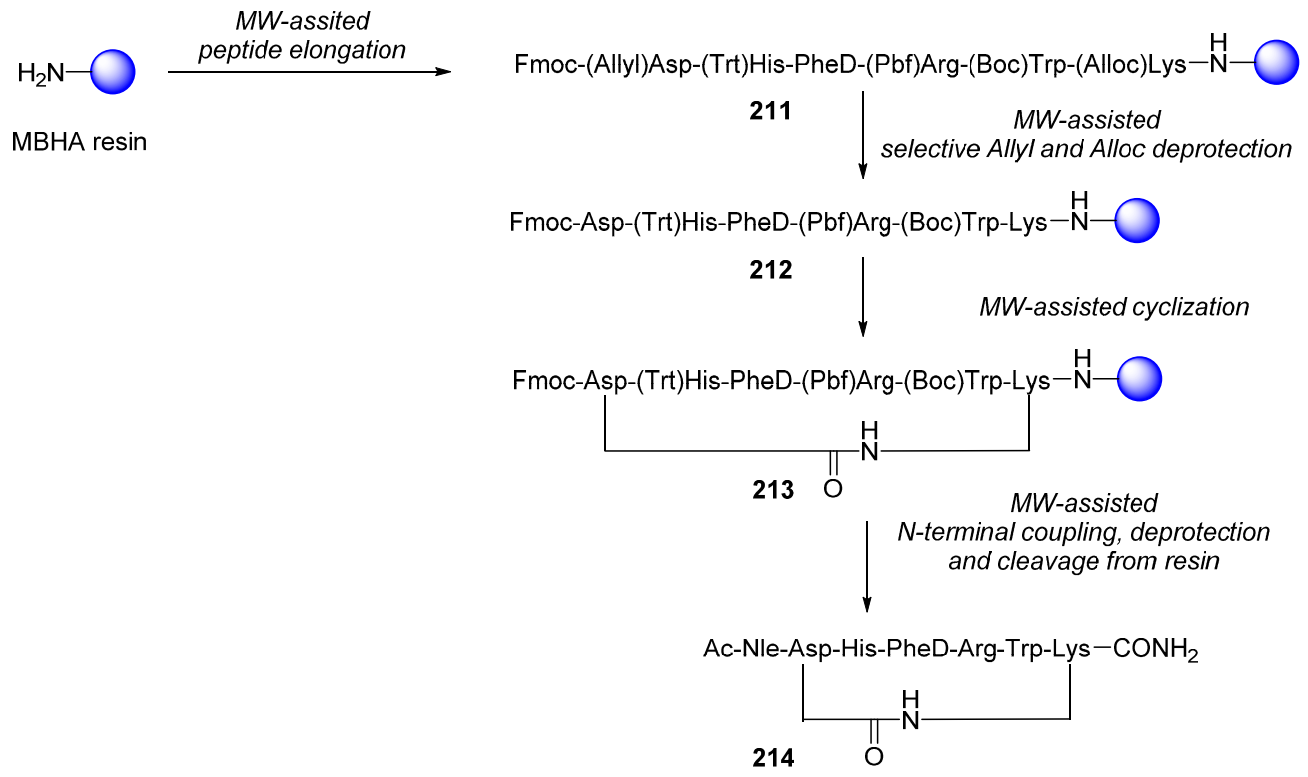

Scheme 43. MW-assisted SPPS and on-resin cyclization of 7-mer peptides.

It is important to note that all steps of this synthesis occurred under MW-activation, from the peptide elongation on the rink amide MBHA resin to the cleavage of the final product. The coupling steps occurred using a standard HBTU/DIEA method in only 5 min under MW irradiation $\left(30 \mathrm{~W}, 75{ }^{\circ} \mathrm{C}\right)$; Fmoc deprotections were performed with $0.1 \mathrm{M} \mathrm{HOBt}$ in a mixture of piperidine and DMF under MW irradiation $\left(30 \mathrm{~W}, 75^{\circ} \mathrm{C}\right)$, leading to 211 in shortened reaction times.

Interestingly, under MW-irradiation $\left(30 \mathrm{~W}, 75^{\circ} \mathrm{C}\right)$, the concomitant and specific Allyl and Alloc deprotection of Lys and Asp has been completed in $2 \mathrm{~min}$ in an open vessel, using a mixture of $\mathrm{PhSiH}_{3}$ (20 eq.) $/ \mathrm{Pd}\left(\mathrm{PPh}_{3}\right)_{4}(0.25$ eq.). This experimental procedure is over-simplified by comparison with the conventional procedure, which proceeds in a sealed vessel, under neutral atmosphere and requires at least $1 \mathrm{~h}$. The resulting peptide $\mathbf{2 1 2}$ is then cyclized in 10 min only under MW-irradiation $\left(30 \mathrm{~W}, 75^{\circ} \mathrm{C}\right)$ using HBTU as coupling agent. This process is also over-simplified, since the conventional lactamization procedure requires a mixture of HBTU/PyBOP/HATU, HOBt and DIEA and is usually 
completed at room temperature in 2-24 h. Finally, the last steps ( $N$-terminal coupling, final deprotection and cleavage from the MBHA resin) occur under MW-irradiation and shortened reaction times.

Another popular strategy used for the preparation of cyclic peptides consists of using a RCM step. In this context, Chapman et al. [84] reported an elegant solid-phase synthesis of hydrogen-bond surrogate (HBS) $\alpha$-helices including a key RCM reaction (Scheme 44 ). In this artificial $\alpha$-helice scaffold, the $\mathrm{N}$-terminal $\mathrm{H}$ bond was replaced by a covalent $\mathrm{C}-\mathrm{C}$ bond.
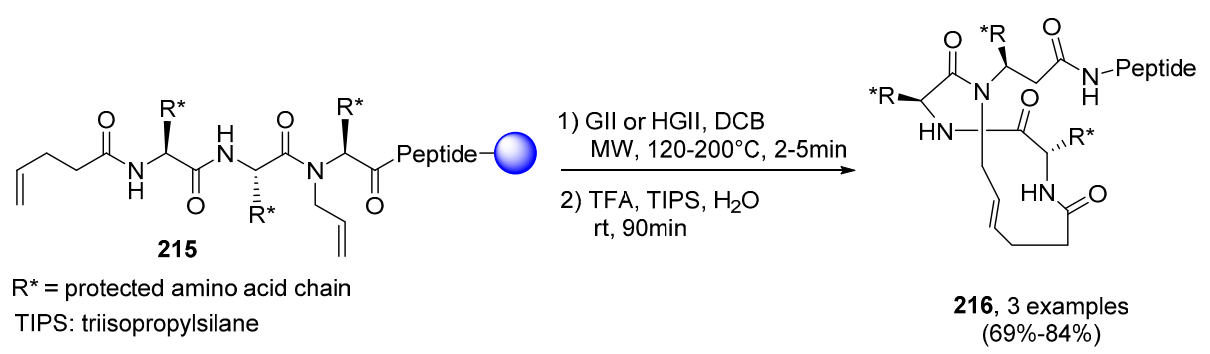

Scheme 44. Example of peptide cyclization through MW-assisted RCM.

In this study, three different 13-membered macrocycles 216 were obtained in high yields. Interestingly, under MW-activation, warming at $120^{\circ} \mathrm{C}$ for $2 \mathrm{~min}$ was required when Grubbs II was employed as catalyst, while warming at $200^{\circ} \mathrm{C}$ for $5 \mathrm{~min}$ was required when using Hoveyda-Grubbs II catalyst. Importantly, both catalysts afforded the expected macrocycles in high yields compared with conventional heating wherein it showed to be inactive.

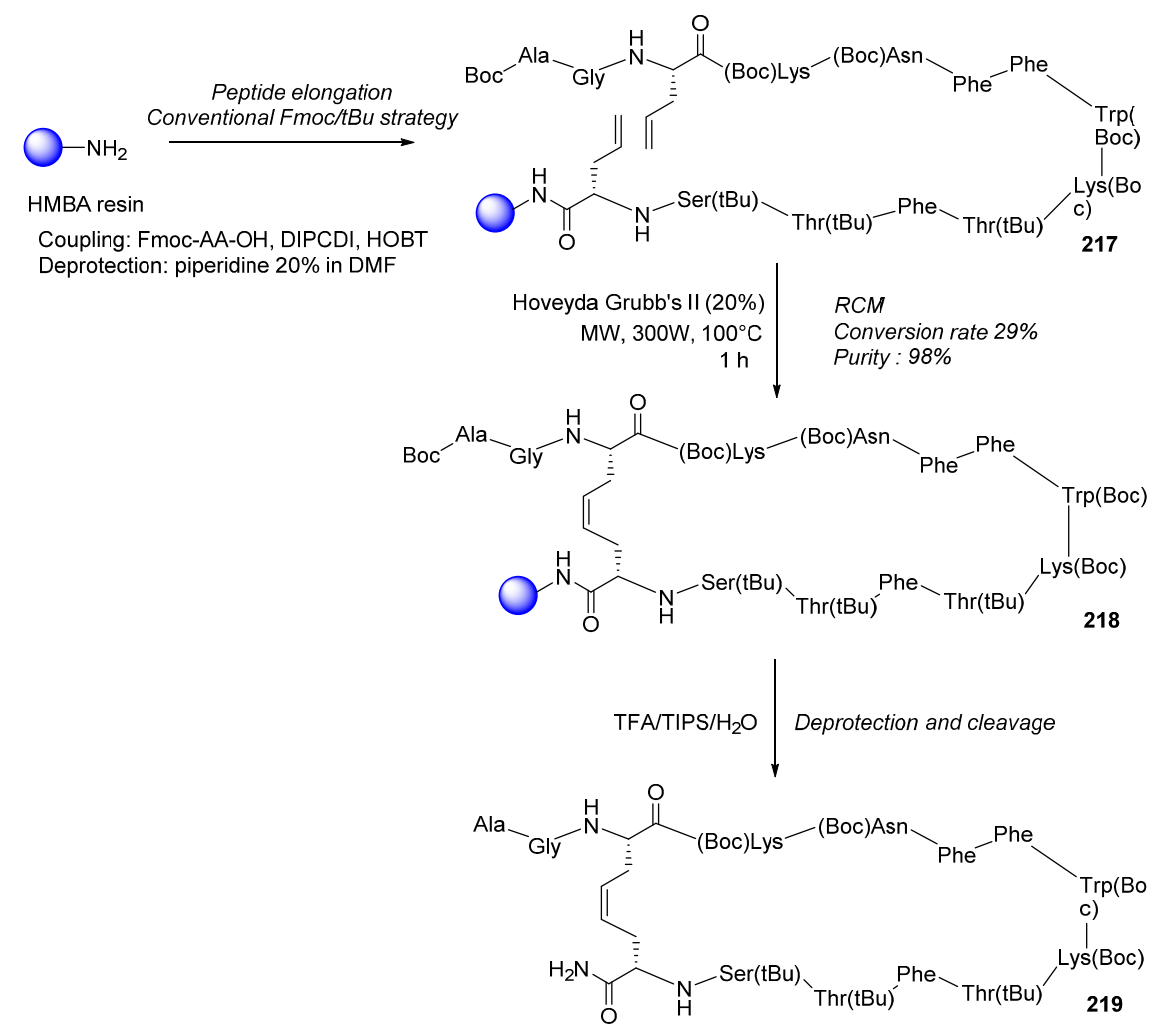

Scheme 45. Synthesis of a 10-mer cyclic through on-resin MW-assisted RCM.

A similar RCM cyclization on an on-resin peptide has been recently used by Gago and co-workers, for the synthesis of a series of somatostatin analogues (Scheme 45) [85]. To compare the effects of the resin on the cyclization step, the peptides have been elongated on two types of resin (chlorotrityl resin 
and HMBA rink amide resin), according to a conventional Fmoc/ $t$ Bu strategy: the authors used a low substitution level on the resins, in order to avoid cross-metathesis. When using the chlorotrityl resin, the authors were unable to obtain a good yield for the cyclization after treatment with Grubb's II catalyst under MW-irradiation $\left(45^{\circ} \mathrm{C}\right.$ or $100{ }^{\circ} \mathrm{C}, 48 \mathrm{~h}$ ). They hypothesized that this result is due to the poor stability and the strong lability of the chlorotrityl resin at high temperatures. However, in the case of the HMBA resin, the authors reported very good results. Indeed, they obtained the required somatostatin analogues with an excellent purity level (up to 98\%) using the Hoveyda-Grubb's II catalyst at $100{ }^{\circ} \mathrm{C}$ and without using a chaotropic agent $(\mathrm{LiCl})$.

Biphenomycin B (225), a natural cyclic peptide with an unusual endo aryl-aryl bond, displays potent activities against Gram-positive $\beta$-lactam-resistant bacteria, and has been recently re-synthesized by Zhu et al. [86] (Scheme 46). The key step of this synthesis is a MW-assisted intramolecular Suzuki-Miyaura cross-coupling reaction involving a linear tripeptide 223, which could be easily obtained from three non-proteinogenic amino acids 220-222. After optimizations, the intramolecular Suzuki-Miyaura coupling afforded the desired macrocycle 225 in $50 \%$ yield.

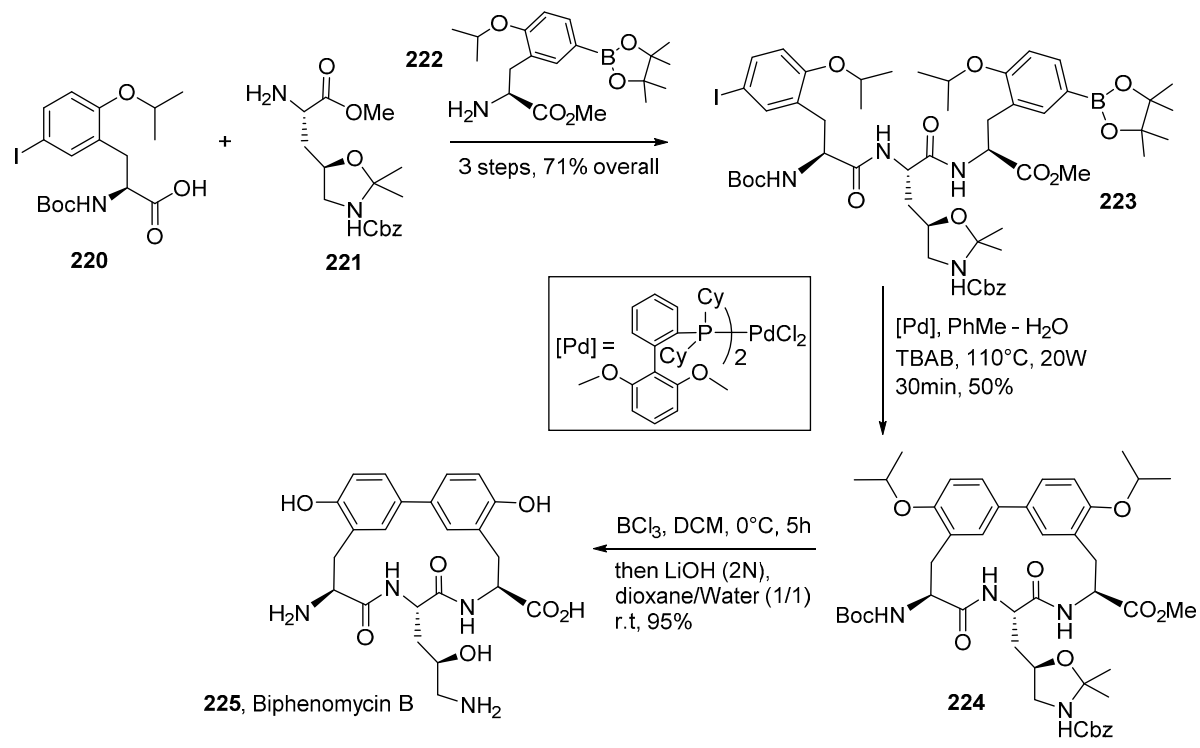

Scheme 46. Synthesis of biphenomycin B via a $\operatorname{Pd}(0)$ C-C bond formation.

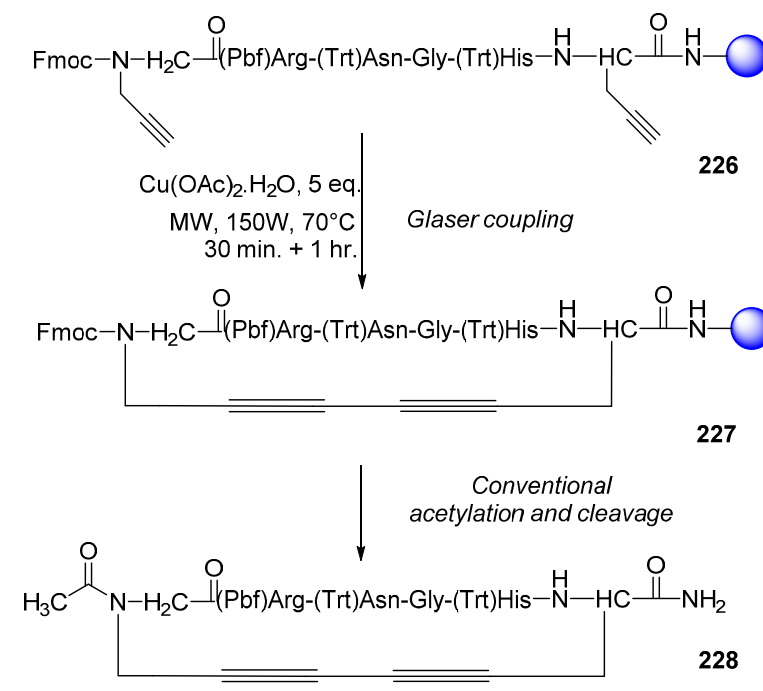

Scheme 47. Peptide cyclization through an on-resin Glaser reaction. 
Mallet and co-workers [87] have recently reported the supported synthesis of 1,3-butadiyne constraint cyclopeptides, which could be obtained through an intramolecular Glaser-Eglinton oxidative coupling managed under MW-irradiation. The Glaser coupling occurs between two terminal alkynes, is catalyzed by a $\mathrm{Cu}(\mathrm{I})$ salt (usually $\left.\mathrm{Cu}(\mathrm{OAc})_{2}\right)$, and proceeds under mild conditions in presence of a source of nitrogen (such as acetonitrile) and of oxygen (Scheme 47).

In this study, the authors report an on-resin method (MBHA rink amide resin), using either propargylglycine or $\mathrm{N}$-propargylglycine located at the two extremities of the peptidic sequence. They highlight the relevance of the MW-activation: indeed, by comparison with conventional heating, MW irradiation allowed shortened reaction times (from $16 \mathrm{~h}$ to less than $90 \mathrm{~min}$ ), and afforded the cyclized peptides in better yields and higher purities (Scheme 47).

An efficient synthesis of side chain-to-tail cyclization of peptoids through an $S_{N} 2$ reaction has been recently reported by Kaniraj and Maayan [88]. Peptoids form an important class of proteolytic-resistant peptidomemetics exhibiting an enhanced cell permeability. The conventional syntheses of chain-to-tail cyclic peptoids include click chemistry reactions, (triazole formation), lactam formation, triazine bridge synthesis and RCM. Each of them is generally efficient, but each of them requires the introduction of a specific functional group. Conversely, the strategy reported by Kaniraj and Maayan is a simple and versatile nucleophilic substitution which leads to the required cyclic peptoid in high yields and with an excellent degree of purity. It is to note that the MW-activation accelerates the reaction (from 4 days to $35 \mathrm{~min}$ ) (Scheme 48 ).

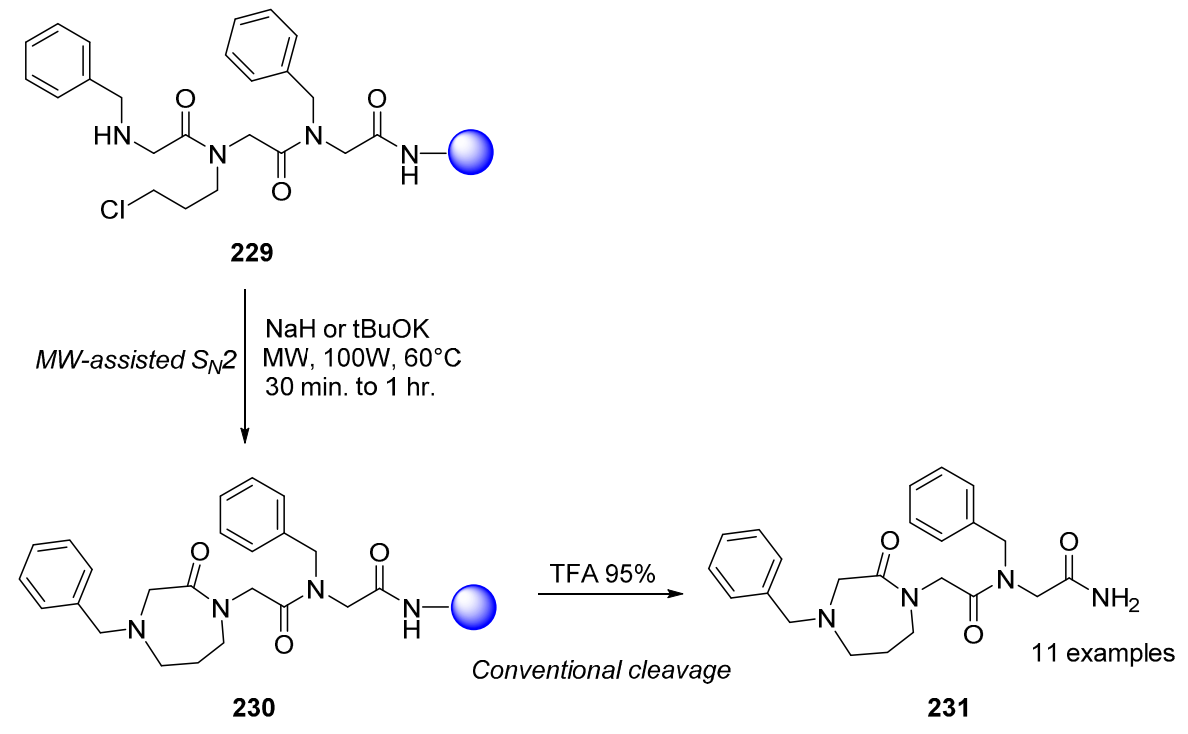

Scheme 48. MW-assisted chain-to-tail cyclization of peptoïds.

\subsubsection{MW-Assisted Syntheses of Macrocyclic Natural Products and Analogues}

(-)-Rhazinilam (233, Scheme 49) is a natural antimitotic compound isolated from Rhazya stricta (Apocynaceae) and from Kopsia singapurensis. This molecule exerts cytotoxic activity in vitro, since it inhibits microtubule assembly and disassembly and induces the abnormal formation of tubulin spirals; (-)-rhazinilam interacts with tubulin in the same range as colchicine $\left(\mathrm{IC}_{50}=2 \mu \mathrm{M}\right)$, but is less potent than vinblastine and taxol, two microtubule trafficking blockers. Moreover, (-)-rhazinilam appears to be inactive in vivo. These results prompted interesting structure-activity relationship studies. (-)-Rhazinilam can be described as an unusual tetracyclic motive, with an axially chiral phenyl (cycle A)-pyrrole (cycle C) subunit linked by a nine-membered lactam cycle (cycle B). Chemical and structural changes in the cycle B retain or enhance the drug's affinity for the tubulin, whereas structural changes in the remaining three cycles induce a total loss of biological activity. 
Therefore, Baudoin's group designed new (-)-rhazinilam derivatives in which the cycle B was enlarged 235, 236 [89].

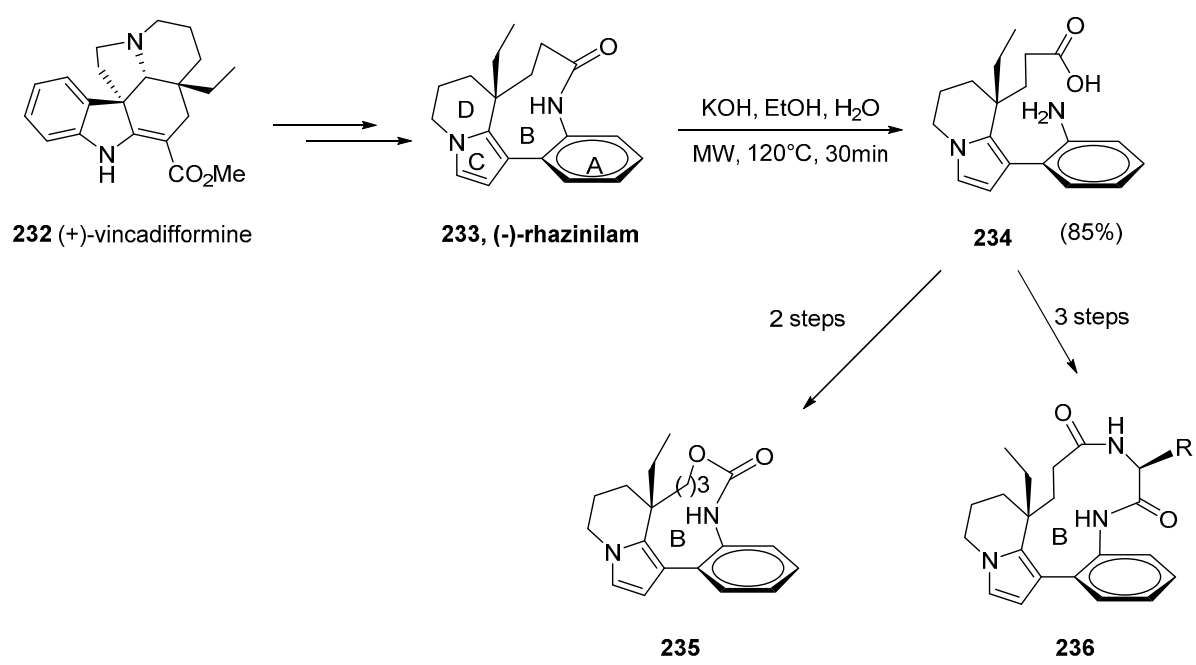

Scheme 49. MW-assisted synthesis of (-)-rhazinilam derivatives.

The corresponding syntheses are outlined in Scheme 49. The initial hydrolysis of the macrolactam (cycle B of rhazinilam) was performed on basic aqueous media, and led to compound 234 [89]. Interestingly, under conventional heating, this reaction requires harsh conditions (excess of $\mathrm{KOH}$, refluxing mixture of water and ethanol, and one day of heating); by a marked contrast, this hydrolysis occurs in only $30 \mathrm{~min}$ and with $85 \%$ of yield under MW-irradiation $\left(120^{\circ} \mathrm{C}, 100 \mathrm{~W}\right.$, sealed tube). The following steps of this synthesis, among them the re-closing step, were performed under conventional procedures. The new series of (-)-rhazinilam derivatives include derivatives with 11- or 12-membered cycle B, which were closed through an endocyclic carbamate linker 235 or an amino-acid motive 236.

The biological assays showed no correlation between the activity of these compounds on tubulin and their cytotoxicity, suggesting the existence of cellular targets which should be elucidated.

The steganacine and steganone are two natural lignin lactones isolated from Steganotaenia araliacea, which interact also with the colchicine binding site of tubulin, and therefore exert anti-mitotic activities. These compounds have a significant cytotoxicity in vivo against P388 leukemia in mice, and in vitro against several cancer cell lines, among them the human nasopharynx carcinoma [89].

Van der Eycken et al. [90] reported recently a MW-assisted nine-step protocol for the synthesis of unnatural derivatives from these two molecules 238, 239 (Scheme 50). The intramolecular cyclization step was carried out following a three-step pseudo one-pot sequence. In the first step, the primary alcohol is converted into bromine through a conventional Appel reaction at room temperature, and using $\mathrm{CBr}_{4}$ and $\mathrm{Ph}_{3} \mathrm{P}$. The resulting intermediate undergoes a $\mathrm{MW}$-assisted nucleophilic substitution, using $\mathrm{NaN}_{3}$ in $\mathrm{DMF}$ at $80^{\circ} \mathrm{C}$.

The last step, consists on a MW-assisted intramolecular Hüisgen 1,3-dipolar cycloaddition between the azide group and the acetylene. This reaction requires higher temperature and leads to the final compound with lower yield when using the ketone derivative $237(43 \%)$ and not the acetate derivative $239(76 \%)$. It is also noteworthy that under conventional heating this intramolecular cycloaddition doesn't occur. In a further work, the same group [91] has explored MW-enhanced Suzuki-Miyaura cross-coupling and ring-closing metathesis (RCM) as key steps for the synthesis of $N$-shifted buflavine analogues. In this preparation, the rigid 8-membered cycle has been obtained through RCM. The best conversion rates have been obtained using 3 mol \% Grubbs II catalyst and under MW-heating for $5 \mathrm{~min}(150 \mathrm{~W})$; indeed, a conventional heating leads to the products with poor yields and requires several hours in refluxing toluene. 


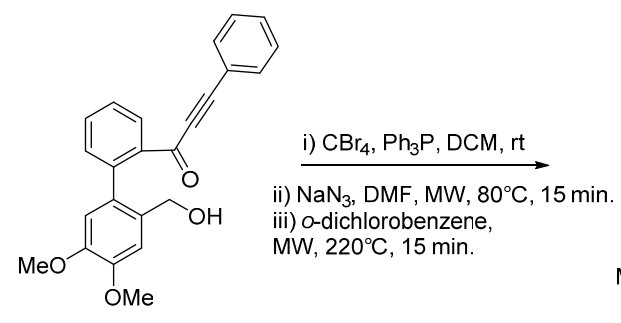

237

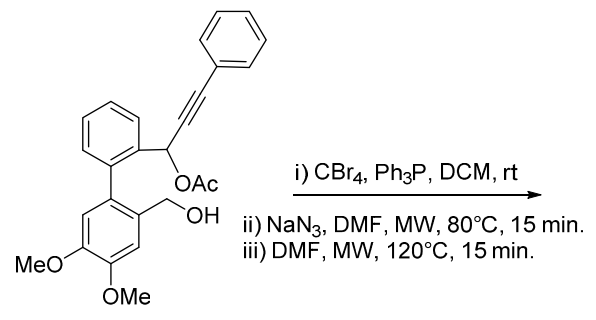

239<smiles>COc1cc2c(cc1OC)-c1ccccc1C(=O)c1c(-c3ccccc3)nnn1C2</smiles>

238<smiles>COc1cc2c(cc1OC)-c1ccccc1C(O)(c1ccccc1)c1nnc(-c3ccccc3)n1C2</smiles>

240
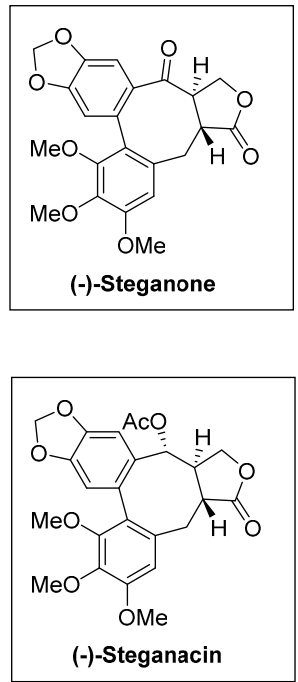

$(-)-$ Steganacin

Scheme 50. MW-assisted synthesis of Steganacin and 8-aza-Steganone.

In 2007, this group reported also the synthesis of ring-expanded and $N$-shifted buflavine analogues (Scheme 51) [92]. This approach includes two key steps: (i) a Suzuki-Miyaura cross-coupling reaction between electron-rich aryl halides 241 and ortho-substituted boronic acids 242 affording the corresponding series of biaryl derivatives 243, 244 and 247; and (ii) a RCM reaction.

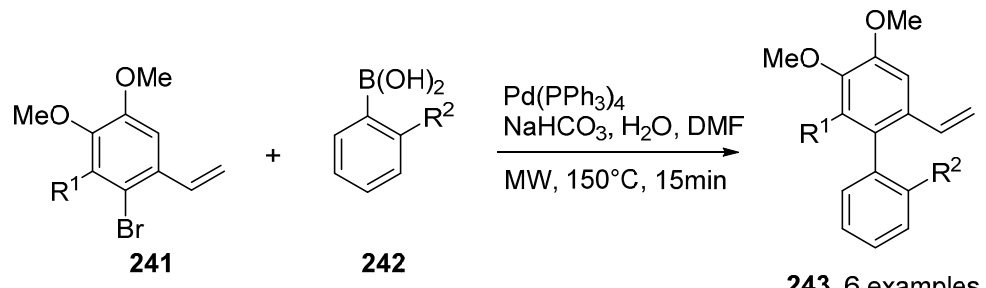

$\mathrm{R}_{1}=\mathrm{H}, \mathrm{OMe}$ (82\%-93\%)

$\mathrm{R}_{2}=\mathrm{NO}_{2}, \mathrm{CHO}, \mathrm{NHC}(\mathrm{O}) t-\mathrm{Bu}$<smiles>[R]c1c(OC)c(OC)cc(C=C)c1-c1ccccc1NC(=O)C(C)(C)C</smiles>

244 $\mathrm{R}_{1}=\mathrm{H}, \mathrm{OMe}$<smiles>[R]c1c(OC)c(OC)cc(C=C)c1-c1ccccc1C=O</smiles>

247<smiles>[R]c1c(OC)cc(C=C)c(-c2ccccc2N(CC=C)C(=O)C(C)(C)C)c1OC</smiles>

245

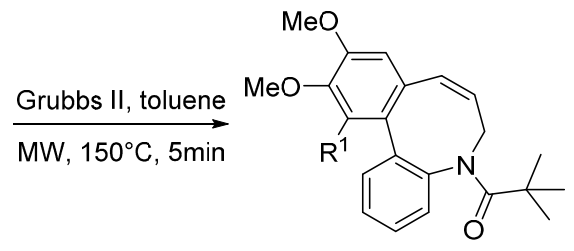

246, 2 examples (68\%-69\%)

$\mathrm{R}_{1}=\mathrm{H}, \mathrm{OMe}$

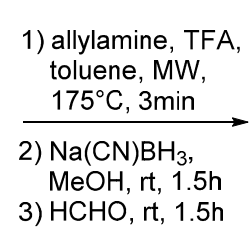

3) $\mathrm{HCHO}, \mathrm{rt}, 1.5 \mathrm{~h}$

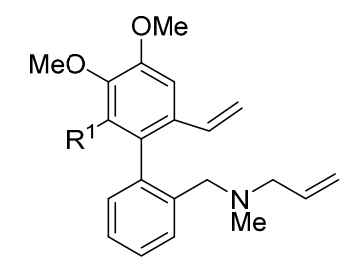

248

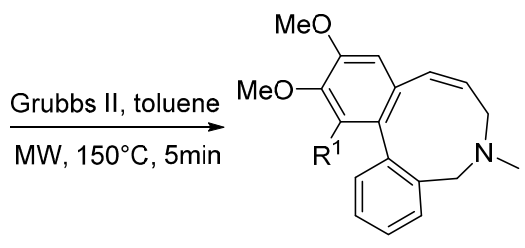

249, 2 examples (54\%-55\%)

Scheme 51. Synthesis of buflavine analogues through a Suzuki-Miyaura cross-coupling and MW-activated RCM sequence. 
The buflavine derivatives encompassing a 8-membered cycle 246 , were obtained by allylation of biaryls 244 and subsequent RCM using Grubb's II catalyst. The buflavine derivatives encompassing a 9-membered cycle 249, were obtained through a reductive amination of the biaryl aldehydes 247 leading to the tertiary amines $\mathbf{2 4 8}$, followed by the RCM reaction. The MW-activation of the RCM is highly beneficial to generate these highly strained ring systems, and leads to the targeted compounds with higher conversion rates compared to those obtained with a conventional heating.

More recently, Shen et al. [93] have performed the synthesis of macrocyclic diaryl ethers 251 via intramolecular and/or bimolecular Ullmann coupling under MW-irradiation (Scheme 52). The authors reported higher yields and shorter reaction times compared with conventional heating and sealed tubes. These macrocyclic diaryl ethers are commonly found in natural compounds (Figure 12) and have been reported to mediate a broad range of biological activities [94-96].<smiles>COc1ccc(CCC(=O)CC(=O)CCc2ccc(Oc3cc(CCCCC(=O)CCc4ccc(OC)c(Br)c4)ccc3OC)c(OC)c2)cc1O</smiles>

Scheme 52. MW-assisted Ullmann coupling leading to macrocyclic diaryl ethers.

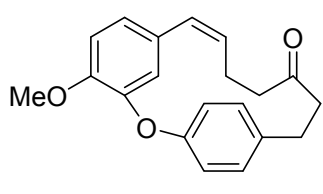

252, Ovalifoliolatin B

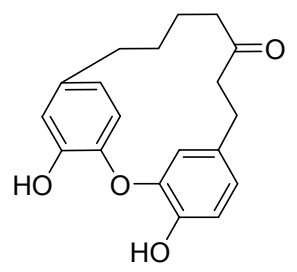

253, Pterocarine

Figure 12. Relevant examples of macrocyclic diaryl ethers as natural compounds.

\subsubsection{MW-Assisted Syntheses of Phthalocyanines}

Another application of MW-irradiation for enhanced macrocycle syntheses has been investigated by Kantekin's group, in the case of metal-free phthalocyanine syntheses [97-100]. Indeed, this novel series of tetrasubstituted metal-free phthalocyanines and metallophthalocyanines is obtained through the MW-activated cyclotetramerization of corresponding dicyano derivatives 254 in 2-(dimethylamino) ethanol for $10 \mathrm{~min}$. The metallophthalo-cyanines 255 were obtained using corresponding anhydrous metal salts $\mathrm{NiCl}_{2}$ and $\mathrm{ZnCl}_{2}, \mathrm{CoCl}_{2}, \mathrm{CuCl}_{2}$, under $\mathrm{MW}$-irradiation in 2-(dimethylamino)ethanol at $175^{\circ} \mathrm{C}$ and $350 \mathrm{~W}$, for $10 \mathrm{~min}$ (Scheme 53) [101].

The same group have reported the synthesis of the metal-free phthalocyanine polymer 257 by the reaction of the tetranitrile monomer 256 with 4-(\{11-[3-cyano-4-(cyanomethyl)phenoxy]-1,5,9,13tetrathiacyclohexadecan-3-yl\}oxy)phthalonitrile in 2-(dimethylamino)ethanol with a set of anhydrous metal salts in DMAE (Scheme 54) [102]. 

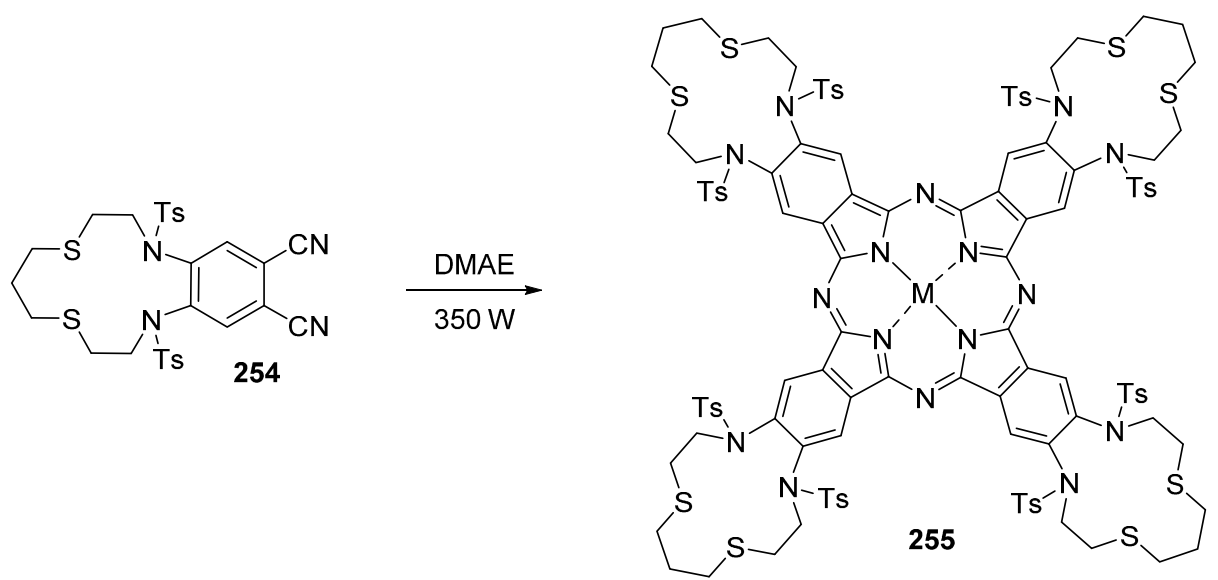

Metal (M) : Zn(II), Cu(II), Co(II), Ni(II)

Scheme 53. MW-assisted synthesis of metallophthalocyanine.

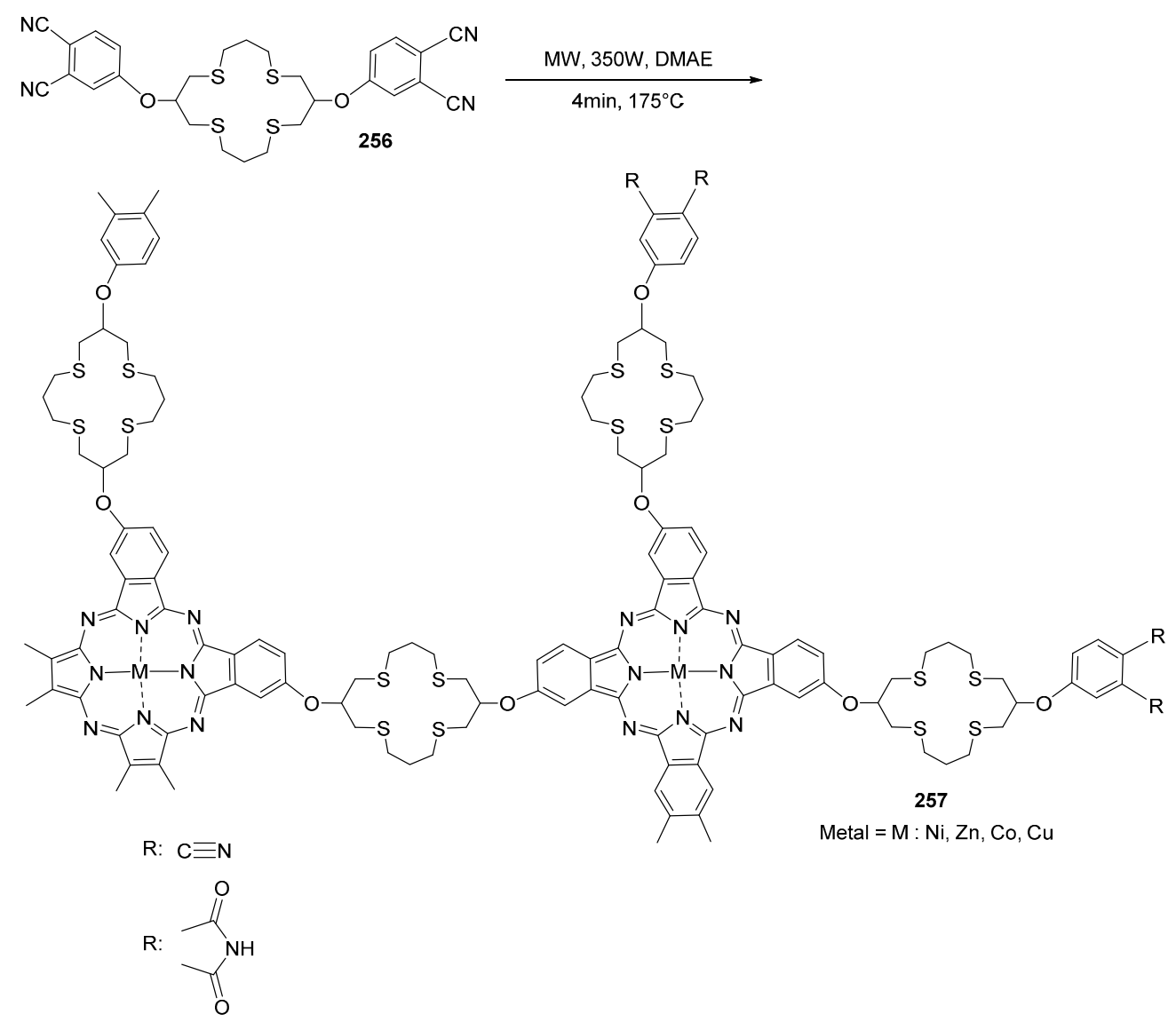

Scheme 54. MW-assisted synthesis of metal-free phthalocyanine polymer.

Recently, novel phthalonitriles and zinc (II) phthalocyanines containng morpholine and/or triazole as pharmacophores have been synthesized by Kantar et al. [103]. In the first step of this synthesis, the triazole $\mathbf{2 6 0}$ has been synthesized through the treatment of compound $\mathbf{2 5 8}$ with 3-morpholinopropylamine 259. Then, the mono- and disubstituted phthalonitrile derivatives 263 and 264 have been obtained by reacting triazole 260, 4-nitro-1,2-dicyanobenzene (261) or 4,5-dichloro-1,2-dicyanobenzene (262) respectively, through base-catalyzed nucleophilic aromatic substitution. Lastly, zinc (II) phthalocyanines 265, 266 have been synthesized from the corresponding 
phthalonitrile derivatives mixed with zinc acetate (Scheme 55). By comparison with conventional heating, the authors reported that MW-assisted syntheses result in higher yields and shortened reaction times. All compounds were screened for anti-xanthine oxidase (anti-XO) activities. The compound 263 exhibited promising $\mathrm{XO}$ inhibition with $\mathrm{IC}_{50}$ value as $0.082 \mathrm{mM}$. Anti-xanthine oxidase activity has not been observed in the case of the phthalocyanines 265 and 266; this latter result is probably due to their potency to form aggregates and their poor solubility.

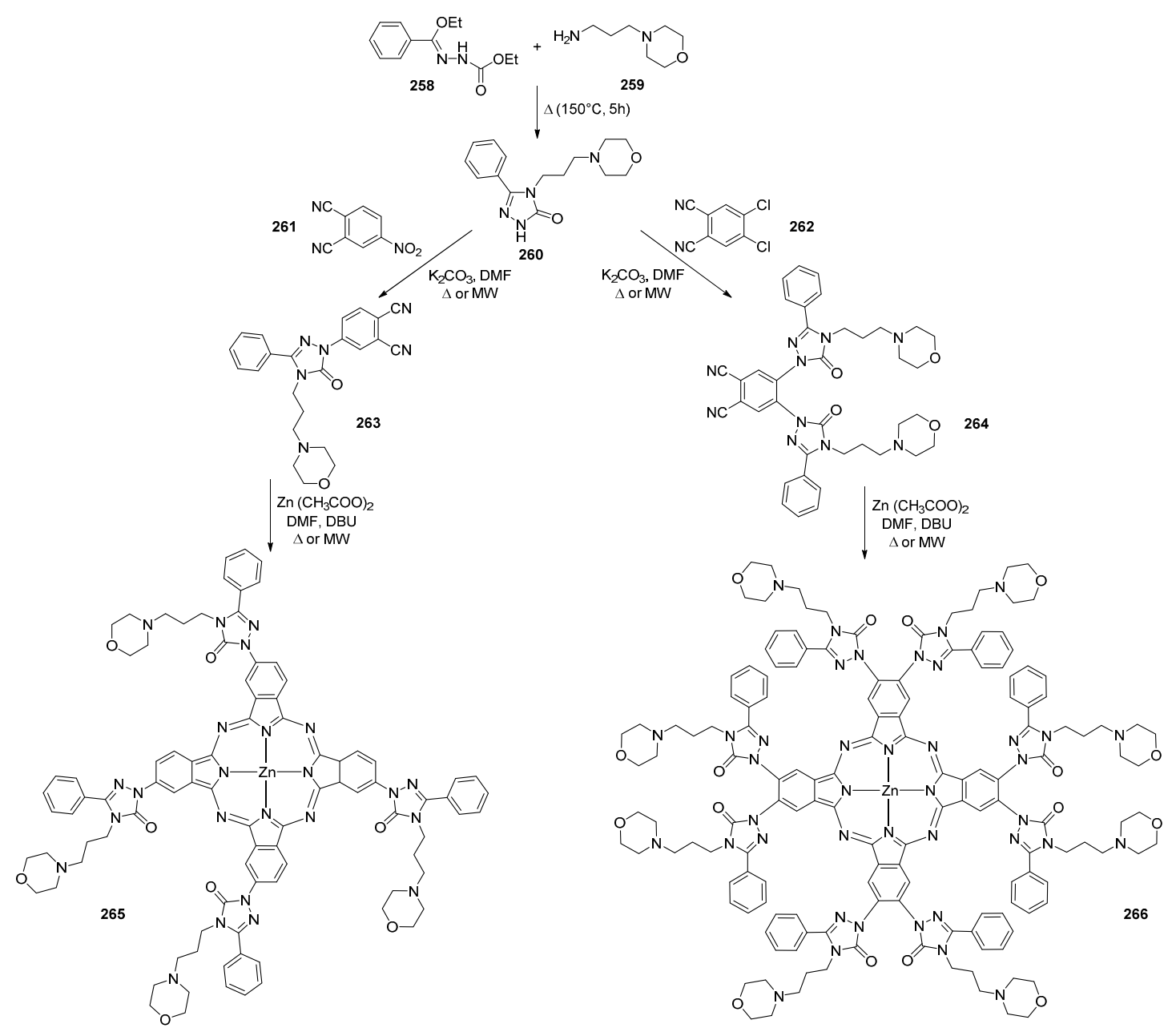

Scheme 55. MW-assisted synthesis of phthalonitriles and zinc (II) phthalocyanines.

\subsubsection{MW-Assisted Syntheses of Calix-Type Derivatives}

The first example of a MW-activated calix-type synthesis has been reported by Srimurugan et al. [104]. In this pioneering work, macrocycle 269 and macrocycle 272 were obtained from dialdehydes 267, 270 and chiral diamines 268, 271, and linked by a Schiff base (imine) as illustrated in Scheme 56.

A similar approach has also been reported by the same group [105] for the synthesis of 24- or new 72-membered chiral macrocyclic Schiff bases through [2+2] or [6+6] cyclocondensations (Scheme 57). Practically, the MW-irradiation of a mixture of 273 and $(1 R, 2 R)$-diammoniumcyclohexane mono-(+)-tartrate (274) in the presence of potassium carbonate afforded two main products 275 and 276 in respectively $14 \%$ and $36 \%$ isolated yield (Scheme 57 ). The corresponding thermal reaction produced the [2+2] macrocycle $\mathbf{2 7 5}$ as the major product, with only a few traces of the [6+6] macrocycle 276 . 


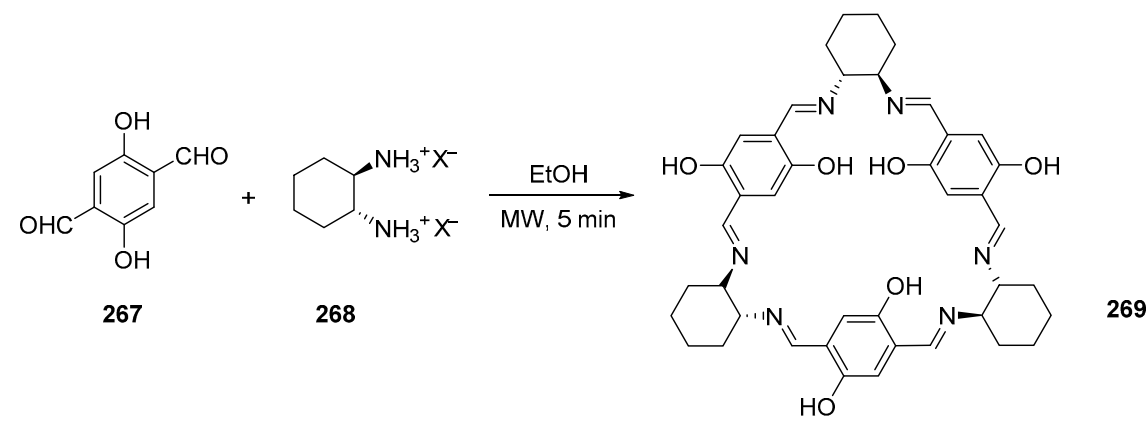<smiles>[R]c1cc([Al]c2cc([R])c(O)c(C=O)c2)cc(C=O)c1O</smiles>

Scheme 56. First example of a MW-activated calix-type synthesis.

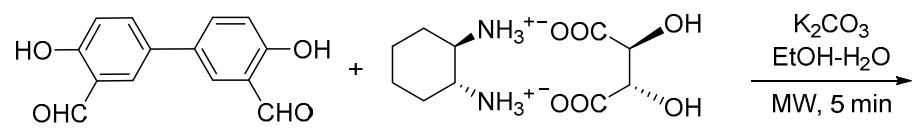

273

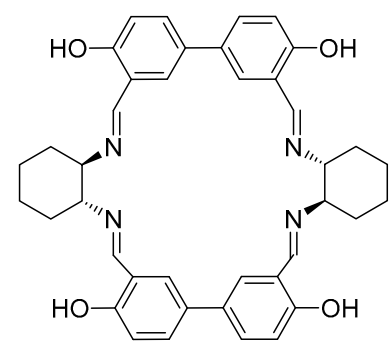

275
274

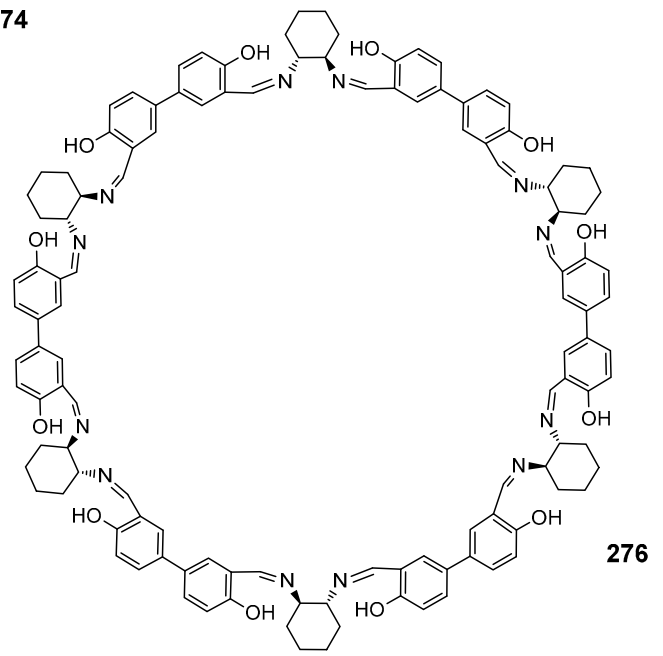

Scheme 57. MW-assisted synthesis of 24- or new 72-membered chiral macrocyclic Schiff bases.

The conventional syntheses of calixarenes occurs through a base-catalyzed condensation of substituted phenols with aldehydes. These reactions require high temperatures, in particular for the synthesis of a cyclic tetramers (calix[4]arene), usually considered as a thermodynamic cyclization product, conversely to the octameric product (calix[8]arene), which is a kinetic adduct.

In this context, some green procedures of variously substituted calix[4]arenes have been published in the last decade. A pioneering work, reported by Yan and co-workers in 2007 [106], described the preparation of pyrogallol[4]arenes $\mathbf{2 8 0}, \mathbf{2 8 1}$, which have been synthesized by reacting equal molar amounts of pyrogallol (277) and substituted aromatic aldehydes 278 in an acidic medium and under 
MW-irradiation (130 W) (Scheme 58). The expected calix[4]arenes 279 have been isolated in good yields $(66 \%-89 \%)$. The reaction times are shortened to only $2-4 \mathrm{~min}$, which is a major improvement by comparison with conventional heating. The subsequent conventional acylation or MW-assisted alkylation of the 12 hydroxy groups, afford compounds 280 and 281, which are soluble in organic media and have been fully characterized by the authors.

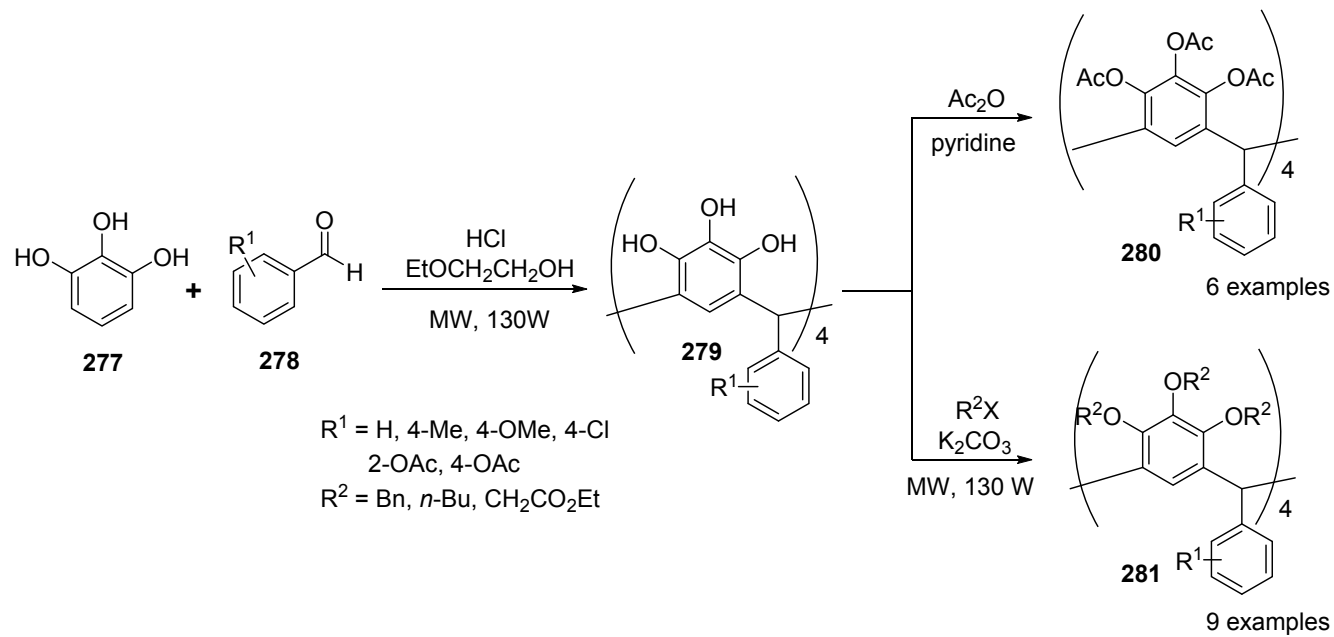

Scheme 58. Green synthesis of calix[4]arenes.

It is noteworthy that similar approaches are still used, as illustrated by the recently published MW-assisted synthesis of three series of calix[4]resorcinarenes 286-288. These derivatives have been isolated by mixing resorcinol (282) with different polysubstituted aromatic aldehydes (including vanillin (283), cinnamaldehyde (285) and p-anisaldehyde (284)) as illustrated in Scheme 59 [107]. Interestingly, the authors underlined in this study the relevance of the reaction time. Indeed, a longer MW-irradiation time leads to the significant reduction of the conversion rate.

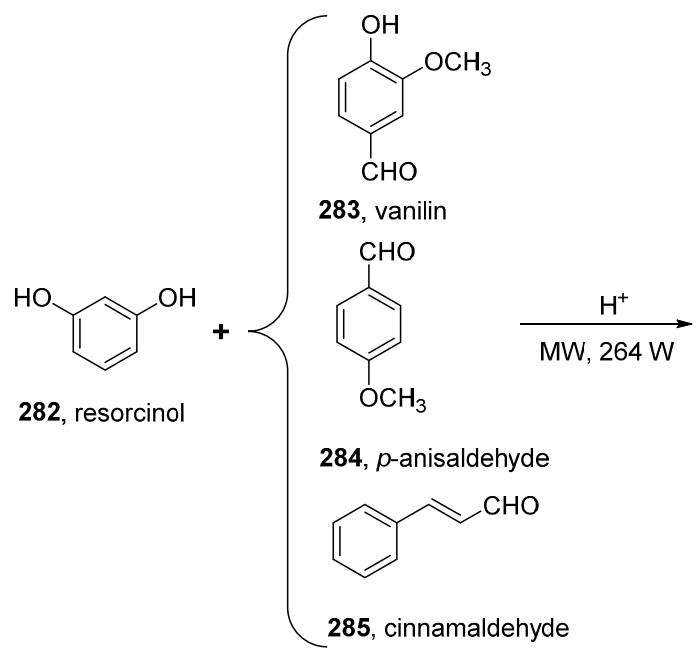

\begin{tabular}{|ccc|}
\hline $282+283:$ & Reaction time & Yield \\
& 4 min. & $94 \%$ \\
6 min. & $97 \%$ \\
7 min. & $96 \%$ \\
9 min. & $67 \%$ \\
\hline
\end{tabular}<smiles>[R]C1c2cc(c(O)cc2O)C([R])c2cc(c(O)cc2O)C([R])c2cc(c(O)cc2O)C([R])c2cc1c(O)cc2O</smiles><smiles>[R]=[V][14c]1ccc(O)c(OC)c1</smiles><smiles></smiles>

$\mathrm{R}=$<smiles>CC=Cc1ccccc1</smiles>

288

Scheme 59. Green synthesis of calix[4]resorcinarenes. 
Finally, it worth mention that MW-irradiation processes have been widely used to functionalize already formed calix[4]arenes (e.g., alkylation of hydroxyls [107-110] or click chemistry linkage [111]).

\section{Conclusions}

The advent of MW technology has profoundly changed the field of organic chemistry. The combination, on the one hand of the prompt and homogeneous heating of the reactants, and on the other hand of the MW non-thermal effects, has allowed the development of new series of highly functionalized molecules which could not by synthesized under conventional heating. In addition, the expected compounds are generally obtained in high yields and excellent purity after shortened reaction times. Moreover, most of the MW-assisted syntheses are highly regio- chemo- and stereo-selective. Importantly, MW-heating is also compatible with green chemistry procedures such as solid-phase and/or solvent-free syntheses.

Macrocycles form a class of natural compounds and synthetic molecules with a large scope of potential therapeutic applications. Therefore, their syntheses have been extensively studied; nevertheless, the cyclisation step is generally very detrimental in terms of yield and purities. Indeed, these reactions are usually characterized by harsh conditions (long reaction times and elevated temperatures and prolonged heating), expensive reagents and solvents, poor regio-, chemo- and stereoselectivity leading to several side products and lastly a marked difficulty in recovering and re-using the catalysts.

By contrast, the use of MW-assisted procedures leads to dramatic optimizations for this specific macrocyclisation step (Figure 13). Taking into account the popularity of MW technology and the number of increasing articles devoted to this topic we selected for this review only relevant examples, in a non-exhaustive way, to illustrate the huge potential of this technology in modern heterocyclic chemistry. This will undoubtedly open the way to other applications and to the design and elaboration new scaffolds and to identify new bioactive molecules.

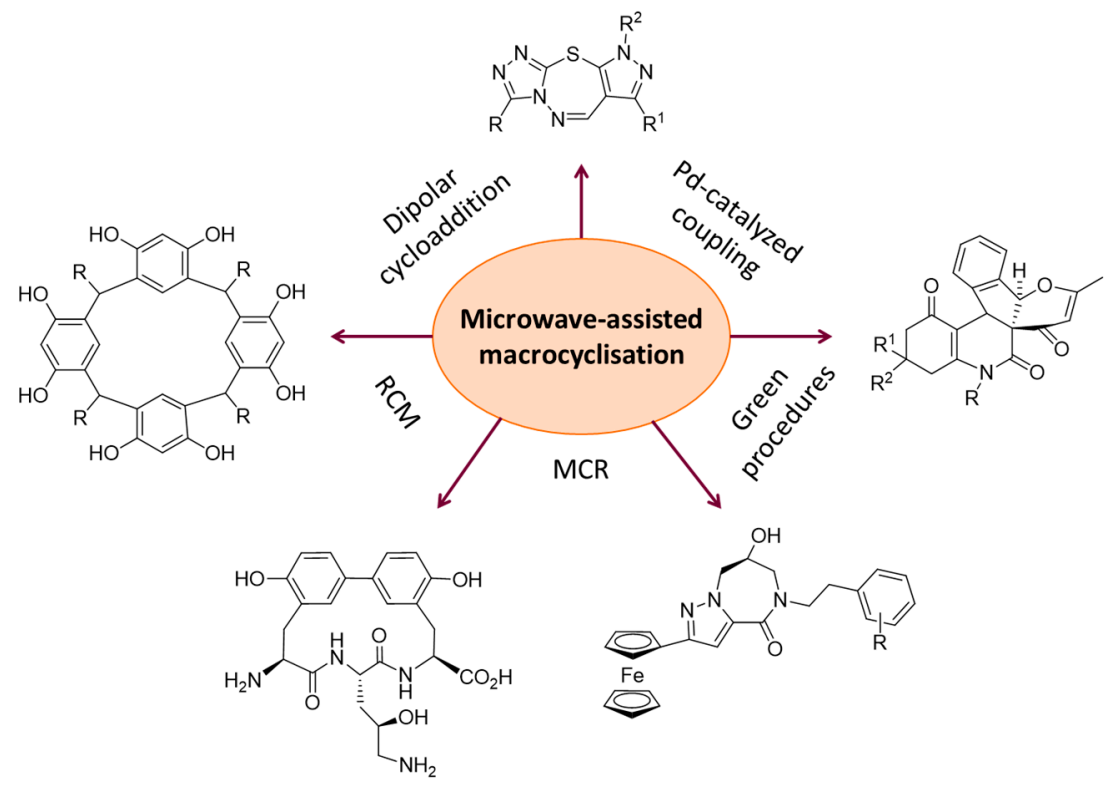

Figure 13. The large scope of the MW-assisted macrocyclisations.

Acknowledgments: This work was funded by grants from the CNRST-Morocco, CNRS-France, the University Mohammed V, Rabat and University of Nice Sophia Antipolis. Also, it was supported by Campus France PHC Toubkal (30330ZF, MA/14/304). The authors are indebted to Philippe Belmont for his invitation to present this work in the Molecules topical issue on Heterocycles. 
Author Contributions: M.D., A.S., H.M., L.D., R.B., K.B. participated in the writing of the review article. All authors read and approved the final manuscript.

Conflicts of Interest: The authors declare no conflict of interest.

\section{Abbreviations}

The following abbreviations are used in this manuscript

\begin{tabular}{|c|c|}
\hline Ac & Acetyle \\
\hline Ala & Alanine \\
\hline Alloc & Allyloxycarbonyl \\
\hline Arg & Arginine \\
\hline Asn & Asparagine \\
\hline Asp & Aspartic acid \\
\hline BET & Bacterial endotoxin test \\
\hline BINAP & 2,2'-Bis(diphenylphosphino)-1,1'-binaphthyl \\
\hline $\mathrm{Bn}$ & Benzyl group \\
\hline Boc & tert-Butyloxycarbonyl \\
\hline $\mathrm{Bu}$ & Butyl \\
\hline $\mathrm{Cbz}$ & Carboxybenzyl \\
\hline CCK2 & Cholecystokinin B \\
\hline CNS & Central Nervous System \\
\hline Cy & Cyclohexyl \\
\hline Cys & Cysteine \\
\hline $\mathrm{Cu}(\mathrm{Phen})\left(\mathrm{PPh}_{3}\right) \mathrm{Br}$ & Bromo-(1,10-phenanthroline- $\left.N, N^{\prime}\right)$ (triphenylphosphine)cuprate \\
\hline $\mathrm{dba}$ & Dibenzylideneacetone \\
\hline DBU & 1,8-Diazabicyclo[5.4.0]undec-7-ene \\
\hline $\mathrm{DCB}$ & 1,4-Dichlorobenzene \\
\hline DDA & Diketene acetone adduct \\
\hline DCM & Dichloromethane \\
\hline DIEA & $N, N$-Diisopropylethylamine \\
\hline DIPCDI & $N, N$-Diisopropylcarbodiimide \\
\hline DMAE & Dimethylethanolamine \\
\hline DMA & Dimethylacetamide \\
\hline DMF & $N, N$-Dimethylformamide \\
\hline DMSO & Dimethyl sulfoxide \\
\hline DNA & Deoxyribonucleic acid \\
\hline Dppf & 1,1'-Bis(diphenylphosphino)ferrocene \\
\hline dr & Diastereomeric ratio \\
\hline ee & Enantiomeric excess \\
\hline eq. & Equivalent \\
\hline Et & Ethyl \\
\hline Fmoc & Fluorenylmethyloxycarbonyl \\
\hline F-SPE & Fluorine solid phase extraction \\
\hline $\mathrm{EtOH}$ & Ethanol \\
\hline GII & Grubbs II catalyst \\
\hline Gly & Glycine \\
\hline HATU & $\begin{array}{l}\text { 1-[Bis(dimethylamino)methylene]- } 1 H-1,2,3 \text {-triazolo[4,5- } b] \text { pyridinium-3-oxid } \\
\text { hexafluorophosphate }\end{array}$ \\
\hline HBS & Hydrogen-bond surrogate \\
\hline HBTU & 2-(1H-Benzotriazol-1-yl)-1,1,3,3-tetramethyluronium hexafluorophosphate \\
\hline HCT 116 & Human colon carcinoma cells \\
\hline His & Histidine \\
\hline HMBA & Hydroxymethylbenzoic acid \\
\hline HGII & Hoveyda-Grubbs II catalyst \\
\hline $\mathrm{HOBt}$ & Hydroxybenzotriazole \\
\hline $\mathrm{IC}_{50}$ & Half maximal inhibitory concentration \\
\hline IL & Ionic Liquid \\
\hline KSAc & Potassium thioacetate \\
\hline Lys & Lysine \\
\hline MBHA & 4-Methylbenzhydryl amine \\
\hline$m-\mathrm{CPBA}$ & meta-Chloroperoxybenzoic acid \\
\hline MCR & Multi-component reaction \\
\hline $\mathrm{Me}$ & Methyl \\
\hline $\mathrm{MeOH}$ & Methanol \\
\hline
\end{tabular}




\begin{tabular}{|c|c|}
\hline MIC & Minimum Inhibitory Concentration \\
\hline Ms & Mesyl \\
\hline mTOR & Mammalian Target of Rapamycin \\
\hline $\min$ & Minute \\
\hline MW & Microwave \\
\hline $\mathrm{NADH}$ & Nicotinamide Adenine Dinucleotide Hydride \\
\hline Nle & Norleucine \\
\hline $\mathrm{Pbf}$ & 2,2,4,6,7-Pentamethyldihydrobenzofuran-5-sulfonyl \\
\hline $\mathrm{Pd} / \mathrm{C}$ & Palladium on carbon \\
\hline PEG & Polyethylene glycol \\
\hline $\mathrm{Ph}$ & Phenyl \\
\hline Phe & Phenylalanine \\
\hline PheD & D-Phenylalanine \\
\hline PMB & p-Methoxybenzyl \\
\hline PPE & Polyphosphoric ester \\
\hline $\mathrm{PPh}_{3}$ & Triphenylphosphine \\
\hline $\operatorname{Pr}$ & Propyl \\
\hline PSSA & Polystyrene sulfonic acid \\
\hline PTH1R & Parathyroid Hormone 1 Receptor \\
\hline PyBOP & Benzotriazol-1-yl-oxytripyrrolidinophosphonium hexafluorophosphate \\
\hline$p$ - $\mathrm{TsOH}$ & para-Toluenesulfonic acid \\
\hline $\mathrm{RCM}$ & Ring closure metathesis \\
\hline r.t & Room temperature \\
\hline Ser & Serine \\
\hline SES & The 2-(trimethylsilyl)ethanesulfonyl group \\
\hline $\mathrm{S}_{\mathrm{N}} \mathrm{Ar}$ & Nucleophilic aromatic substitution \\
\hline SPPS & Solid Phase Peptide Synthesis \\
\hline TBAB & Tetrabutylammonium bromide \\
\hline TFA & Trifluoroacetic acid \\
\hline Thr & Threonine \\
\hline TIPS & Triisopropylsilyl \\
\hline TMS & Trimethylsilyl \\
\hline $\operatorname{Trp}$ & Tryptophan \\
\hline Trt & Trityl (triphenylmethyl) \\
\hline Ts & Tosyl \\
\hline THF & Tetrahydrofuran \\
\hline $\mathrm{XO}$ & Xanthine Oxidase \\
\hline
\end{tabular}

\section{References}

1. Kappe, C.O.; Dallinger, D. Controlled microwave heating in modern organic synthesis: highlights from the 2004-2008 literature. Mol. Divers. 2009, 13, 71-193. [CrossRef] [PubMed]

2. De La Hoz, A.; Loupy, A. Microwave in Organic Synthesis, 3rd ed.; Wiley-WCH: Weinheim, Germany, 2012.

3. Saber, A.; Marzag, H.; Benhida, R.; Bougrin, K. Microwave-assisted cycloaddition reactions in carbo- and heterocyclic chemistry. Curr. Org. Chem. 2014, 18, 2139-2180. [CrossRef]

4. Driowya, M.; Saber, A.; Marzag, H.; Demange, L.; Benhida, R.; Bougrin, K. Microwave-assisted synthesis of bioactive six-membered heterocycles and their fused analogues. Molecules 2016, 21, 492. [CrossRef] [PubMed]

5. Shah, J.H.; Hindupur, R.M.; Pati, H.N. Pharmacological and biological activities of benzazepines: An overview. Curr. Bioact. Compd. 2015, 11, 170-188. [CrossRef]

6. Lin, H.-C.; Chiou, G.; Chooi, Y.-H.; MacMahon, T.C.; Xu, W.; Garg, N.K.; Tang, Y. Elucidation of the concise biosynthetic pathway of the communesin indole alkaloids. Angew. Chem. 2015, 54, 3004-3007. [CrossRef] [PubMed] 
7. Gozler, T.; Gozler, B.; Weiss, I.; Freyer, A.J.; Shamma, M. (+)-Turkiyenine: An unusual extension of the biogenetic sequence for the isoquinoline alkaloids. J. Am. Chem. Soc. 1984, 106, 6101-6102. [CrossRef]

8. Li, H.; Wen, Y.; Wang, F.; Wu, P.; Wei, X. Cephalofortunone, a structurally unique cephalotaxus alkaloid from Cephalotaxus fortune Hook. F. Tetrahedron Lett. 2015, 56, 5735-5737. [CrossRef]

9. Chung, H.-S.; Hon, P.-M.; Lin, G.; But, P.P.-H.; Dong, H. Antitussive activity of Stemona alkaloids from Stemona tuberosa. Planta Med. 2003, 69, 914-920. [PubMed]

10. Declerck, V.; Ribière, P.; Nédellec, Y.; Allouchi, H.; Martinez, J.; Lamaty, F. A Microwave-Assisted Heck Reaction in Poly(ethylene glycol) for the Synthesis of Benzazepines. Eur. J. Org. Chem. 2007, 38, 201-208. [CrossRef]

11. Viladomat, F.; Bastida, J.; Codina, C.; Campbell, W.E.; Mathee, S. Alkaloids from Boophane flava. Phytochemistry 1995, 40, 307-311. [CrossRef]

12. Ying, G.; de Andrade, J.P.; Pigni, N.B.; Torras-Claveria, L.; Tallini, L.R.; Borges, W.D.S.; Viladomat, F.; Nair, J.J.; Zuanazzi, J.A.S.; Bastida, J. New alkaloids from Hippeastrum papilio (Ravenna) van Scheepen. Helv. Chim. Acta 2016, 99, 143-147.

13. Bariwal, J.B.; Ermolat'ev, D.S.; Glasnov, T.N.; Van Hecke, K.; Mehta, V.P.; Van Meervelt, L.; Kappe, C.O.; Van der Eycken, E.V. Dibenzoazocines and dibenzoazepines via a microwave-assisted intramolecular A3-coupling reaction. Org. Lett. 2010, 12, 2774-2777. [CrossRef] [PubMed]

14. Donets, P.A.; van der Eycken, E.V. Synthesis of ring-expanded aza-analogues of bisbenzocyclooctadiene lignin lactones. QSAR Comb. Sci. 2007, 26, 1239-1242. [CrossRef]

15. Donets, P.A.; Goeman, J.L.; Van der Eycken, J.; Robeyns, K.; van Meervelt, L.; van der Eycken, E.V. An asymmetric approach towards (-)-aphanorphine and its analogues. Eur. J. Org. Chem. 2009, 25, 793-796. [CrossRef]

16. Peshkov, V.A.; Pereshivko, O.P.; Donets, P.A.; Mehta, V.P.; van der Eycken, E.V. Diversity-oriented microwave-assisted synthesis of the 3-benzazepine framework. Eur. J. Org. Chem. 2010, 25, 4861-4867. [CrossRef]

17. Sarkar, S.; Husain, S.M.; Schepmann, D.; Frölich, R.; Wünsch, B. Microwave assisted synthesis of 3-benzazepin-2-ones as building blocks for 2,3-disubstituted tetrahydro-3-benzazepines. Tetrahedron 2012, 68, 2687-2695. [CrossRef]

18. Manabe, Y.; Kanematsu, M.; Yokoe, H.; Yoshida, M.; Shishido, K. Concise total synthesis of heliannuols B and D. Tetrahedron 2014, 70, 742-748. [CrossRef]

19. Engler, M.; Anke, T.; Sterner, O. Pterulinic acid and pterulone, two novel inhibitors of NADH: Ubiquinone oxidoreductase (complex I) produced by a Pterula species. I. Production, isolation and biological activities. J. Antibiot. 1997, 50, 330-333. [CrossRef] [PubMed]

20. Lee, I.-K.; Jang, Y.-W.; Kim, Y.-S.; Yu, S.H.; Lee, K.J.; Park, S.-M.; Oh, B.-T.; Chae, J.-C.; Yun, B.-S. Xylarinols A and B, two new 2-benzoxepin derivatives from the fruiting bodies of Xylaria polymorpha. J. Antibiot. 2009, 62, 163-165. [CrossRef] [PubMed]

21. Muscarella, M.; Kimber, M.C.; Moody, C.J. Synthesis of ptaeroxylin (desoxykarenin): An unusual chromone from the sneezewood tree Ptaeroxylon obliquum. Synlett 2008, 14, 2101-2102.

22. Jiang, B.; Feng, B.-M.; Wang, S.-L.; Tu, S.-J.; Li, G. Domino constructions of pentacyclic indeno[2,1-c]quinolones and pyrano[4,3-b]oxepines by $[4+1] /[3+2+1] /[5+1]$ and $[4+3]$ multiple cyclisations. Chem. Eur. J. 2012, 18, 9823-9826. [CrossRef] [PubMed]

23. Bruder, M.; Haseler, P.L.; Muscarella, M.; Lewis, W.; Moody, C.J. Synthesis of the oxepinochrome natural products ptaeroxylin (desoxykarenin), ptaeroxylinol, and eranthin. J. Org. Chem. 2010, 75, 353-358. [CrossRef] [PubMed]

24. Castedo, L.; Suau, R. Cularine alkaloids. Alkaloids 1986, 29, 287-324.

25. Wu, B.; He, S.; Pan, Y.-J. New dihydrodibenzoxepins from bulbophyllum kwangtungense. Planta Med. 2006, 72, 1244-1247. [CrossRef] [PubMed]

26. Kittakoop, P.; Nopichai, S.; Thongon, N.; Charoenchai, P.; Thebtaranonth, Y. Bauhinoxepins A and B: New antimycobacterial dibenzo $[b, f]$ oxepins from Bauhinia saccocalyx. Helv. Chim. Acta 2004, 87, 175-179. [CrossRef]

27. Trabanco, A.A.; Alonso, J.M.; Andres, J.I.; Cid, J.M.; Fernández, J.; Iturrino, L.; Megens, A. Synthesis of $2-N, N$-dimethylaminomethyl-2,3,3a, 12b-tetrahydrodibenzo $[b, f]$ furo[2,3- $d]$ oxepin as potential anxiolytic agents. Chem. Pharm. Bull. 2004, 52, 262-265. [CrossRef] [PubMed] 
28. Nagai, Y.; Irie, A.; Nakamura, H.; Hino, K.; Uno, H.; Nishimura, H. Nonsteroïdal antiinflammatory agents. 1. 10,11-Dihydro-11-oxodibenz $[b, f]$ oxepinacetic acids and related compounds. J. Med. Chem. 1982, 25, 1065-1070. [CrossRef] [PubMed]

29. Moreno, D.R.R.; Giorgi, G.; Salas, C.O.; Tapia, R.A. New short strategy for the synthesis of the dibenzo[ $b, f$ ]oxepin scaffold. Molecules 2013, 18, 14797-14806. [CrossRef] [PubMed]

30. Ansari, M.I.; Hussain, M.K.; Arun, A.; Chakravarti, B.; Konwar, R.; Hajela, K. Synthesis of targeted dibenzo $[b, f]$ thiepines and dibenzo $[b, f]$ oxepines as potential lead molecules with promising anti-breast cancer activity. Eur. J. Med. Chem. 2015, 99, 113-124. [CrossRef] [PubMed]

31. Green, B. Zotepine: A clinical review. Expert Opin. Drig Metab. Toxicol. 2009, 5, 181-186. [CrossRef] [PubMed]

32. Kristensen, J.L.; Puschl, A.; Jensen, M.; Risgaard, R.; Christiffersen, C.T.; Bang-Andersen, B.; Balle, T. Exploring the neuroleptic substituent in octoclothepin: Potential ligand for positron emission tomography with subnanomola affinity for $\alpha 1$-adrenocaptors. J. Med. Chem. 2010, 53, 7021-7034. [CrossRef] [PubMed]

33. Bozinovic, N.; Novakovic, I.; Kostic Rajacic, S.; Opsenica, I.M.; Solaja, B.A. Synthesis and antimicrobial activity of azepine and thiepine derivatives. J. Serb. Chem. Soc. 2015, 80, 839-852. [CrossRef]

34. Bozinovic, N.; Opsenica, I.; Solaja, B. Double palladium-catalyzed synthesis of azepines. Synlett 2013, 24, 49-52.

35. Costantino, L.; Barlocco, D. Privileged Structures as Leads in Medicinal Chemistry. Curr. Med. Chem. 2006, 13, 65-85. [CrossRef] [PubMed]

36. James, G.L.; Goldstein, J.L.; Brown, M.S.; Rawson, T.E.; Somers, T.C.; McDowell, R.S.; Crowley, C.W.; Lucas, B.K.; Levinson, A.D.; Marsters, J.C., Jr. Benzodiazepine peptidomimetics: Potent inhibitors of Ras farnesylation in animal cells. Science 1993, 260, 1937-1942. [CrossRef] [PubMed]

37. Papageorgiou, C.; Borer, X. A non-peptide ligand for the somatostatin receptor having a benzodiazepinone structure. Bioorg. Med. Chem. Lett. 1996, 6, 267-272. [CrossRef]

38. Manih, R.M.; Myrboh, B. A facile synthesis of 3,5,7-trisubstituted-4H-[1,2]diazepines by microwave irradiation. Indian J. Chem. Sec. B 2012, 51B, 1613-1618.

39. Díaz, J.E.; Bisceglia, J.A.; Mollo, M.C.; Orelli, L.R. 1,n-Diamines. Part 2: Synthesis of acyclic and heterocyclic $\mathrm{N}$-arylputrescine derivatives. Tetrahedron Lett. 2011, 52, 1895-1897. [CrossRef]

40. Bisceglia, J.A.; Diaz, J.E.; Torres, R.A.; Orelli, L.R. 1,n-diamines. Part 3: Microwave-assisted synthesis of $N$-acyl-N'-arylhaxahydropyrimidines and hexahydo-1,3-diazepines. Tetrahedron Lett. 2011, 52, 5238-5240. [CrossRef]

41. Morrison, C.S.; Lampe, J.B.; Kolodziejczyk, T.C.; Cavazos, R.J.; Petros, R.A. Rapid, quantitative, solvent-free synthesis of medium-ring diaza heterocycles from diketene-acetone adduct and diamines. Tetrahedron Lett. 2014, 55, 6547-6549. [CrossRef]

42. Liang, L.; Saiz, C.; Pizzo, C.; Wipf, P. Synthesis of pyrrolo[1,3]diazepines by a dipolar cycloaddition—Retro-Mannich domino reaction. Tetrahedron Lett. 2009, 50, 6810-6813. [CrossRef] [PubMed]

43. Shen, S.L.; Shao, J.H.; Luo, J.Z.; Liu, J.T.; Miao, J.M.; Zhao, B.X. Novel chiral ferrocenylpyrazolo[1,5-a] diazepin-4-one derivatives-Synthesis, characterization and inhibition against lung cancer cells. Eur. J. Med. Chem. 2013, 63, 256-268. [CrossRef] [PubMed]

44. Shen, S.L.; Zhu, J.; Li, M.; Zhao, B.X.; Miao, J.Y. Synthesis of ferrocenyl pyrazole-containing chiral aminoethanol derivatives and their inhibition against A549 and H322 lung cancer cells. Eur. J. Med. Chem. 2012, 54, 287-294. [CrossRef] [PubMed]

45. Bougrin, K.; Bennani, K.A.; Tétouani, S.F.; Soufiaoui, M. An easy route to synthesize 1,5-arylodiazepin-2-ones. Tetrahedron Lett. 1994, 35, 8373-8376. [CrossRef]

46. Polshettiwar, V.; Varma, R.S. Greener and rapid access to bio-active heterocycles: Room temperature synthesis of pyrazoles and diazepines in aqueous medium. Tetrahedron Lett. 2008, 49, 397-400. [CrossRef]

47. Insuasty, B.; García, A.; Quiroga, J.; Abonia, R.; Nogueras, M.; Cobo, J. Synthesis of novel 6,6a,7,8-tetrahydro-5H-naphtho[1,2-e]pyrimido[4,5-b][1,4]diazepines under microwave irradiation as potential anti-tumor agents. Eur. J. Med Chem. 2010, 45, 2841-2846. [CrossRef] [PubMed]

48. Vaddula, B.R.; Varma, R.S.; Leazer, J. Mixing with microwaves: Solvent-free and catalyst-free synthesis of pyrazoles and diazepines. Tetrahedron Lett. 2013, 54, 1538-1541. [CrossRef]

49. Willy, B.; Dallos, T.; Rominger, F.; Schönhaber, J.; Müller, T.J.J. Three-Component Synthesis of Cryofluorescent 2,4-Disubstituted 3H-1,5-Benzodiazepines-Conformational Control of Emission Properties. Eur. J. Org. Chem. 2008, 4796-4805. [CrossRef] 
50. Zhang, W. Fluorous-Enhanced Multicomponent Reactions for Making Drug-Like Library Scaffolds. Comb. Chem. High Throughput Screen. 2007, 10, 219-229. [CrossRef] [PubMed]

51. Wang, S.L.; Cheng, C.; Wu, F.Y.; Jiang, B.; Shi, F.; Tu, S.J.; Rajale, T.; Li, G. Microwave-assisted multi-component reaction in water leading to highly regioselective formation of benzo[f]azulen-1-ones. Tetrahedron 2011, 67, 4485-4493. [CrossRef] [PubMed]

52. Ohta, Y.; Chiba, H.; Oishi, S.; Fujii, N.; Ohno, H. Concise Synthesis of Indole-Fused 1,4-Diazepines through Copper(I)-Catalyzed Domino Three-Component Coupling-Cyclization-N-Arylation under Microwave Irradiation. Org. Lett. 2008, 10, 3535-3538. [CrossRef] [PubMed]

53. Acosta, P.; Becerra, D.; Goudedranche, S.; Quiroge, J.; Constantieux, T.; Bonne, D.; Rodriguez, J. Exploiting the reactivity of 1,2-ketoamides: Enantioselective synthesis of functionalized pyrrolidines and pyrrolo-1,4-benzodiazepine-2,5-diones. Synlett 2015, 26, 1591-1595. [CrossRef]

54. Hopenwasser, J.; Mozayani, A.; Danielson, T.J.; Harbin, A.; Narula, H.S.; Posey, D.H.; Shrode, P.W.; Wilson, S.K.; Li, R.; Sanchez, L. Postmortem Distribution of the Novel Antipsychotic Drug Quetiapine. J. Anal. Toxicol. 2004, 28, 264-268. [CrossRef] [PubMed]

55. Bocquet, A.; Sablayrolles, S.; Vacher, B.; Le Grand, B. F15845, a new blocker of the persistent sodium current prevents consequences of hypoxia in rat femoral artery. Br. J. Pharmacol. 2010, 161, 405-415. [CrossRef] [PubMed]

56. Yadav, D.B.; Morgans, G.L.; Aderibigbe, B.A.; Madeley, L.G.; Fernandes, M.A.; Michael, J.P.; de Koning, C.B.; Van Otterlo, W.A.L. Application of an isomerization-ring-closing metathesis strategy to the synthesis of unsaturated seven-membered, benzo-fused heterocycles containing two heteroatoms. Tetrahedron 2011, 67, 2991-2997. [CrossRef]

57. Saha, D.; Wadhwa, P.; Sharma, A. A sequential synthetic strategy towards unexplored dibenzo[ $b, f][1,4]$ thiazepine carboxamides: Copper catalysed C-S cyclisation followed by Ugi type 3CC cascade. RSC Adv. 2015, 5, 33067-33076. [CrossRef]

58. Tu, S.J.; Cao, X.D.; Hao, W.G.; Zhang, X.H.; Yan, S.; Wu, S.S.; Han, Z.G.; Shi, F. An efficient and chemoselective synthesis of benzo[ $e][1,4]$ thiazepin-2 $(1 H, 3 H, 5 H)$-ones via a microwave-assisted multi-component reaction in water. Org. Biomol. Chem. 2009, 7, 557-563. [CrossRef] [PubMed]

59. Shi, F.; Zeng, X.N.; Cao, X.D.; Zhang, S.; Jiang, B.; Zheng, W.F.; Tu, S.G. Design and diversity-oriented synthesis of novel 1,4-thiazepan-3-ones fused with bioactive heterocyclic skeletons and evaluation of their antioxidant and cytotoxic activities. Bioorg. Med. Chem. Lett. 2012, 22, 743-746. [CrossRef] [PubMed]

60. Keating, G.M. Loxapine inhalation powder: A review of its use in the acute treatment of agitation in patients with bipolar disorders of schizophrenia. CNS Drugs 2013, 27, 479-489. [CrossRef] [PubMed]

61. Blaquiere, N.; Do, S.; Dudley, D.; Folkes, A.J.; Heald, R.; Heffron, T.; Jones, M.; Kolesnikov, A.; Ndubaku, C.; Olivero, A.G.; et al. Benzoxazepine as PI3K Inhibitor and Their Preparation and Use in the Treatment of Cancer. PCT Patent WO 2011036280 A1 20110331, 31 March 2011.

62. Takeuchi, C.S.; Kim, B.G.; Blazey, C.M.; Ma, S.; Johnson, W.B.; Anand, N.K.; Arcalas, A.; Baik, T.G.; Buhr, C.A.; Cannoy, J.; et al. Discovery of a novel class of highly potent, selective, ATP-competitive, and orally bioavailable inhibitors of the mammalian target of rapamycin (mTOR). J. Med. Chem. 2013, 56, 2218-2234. [CrossRef] [PubMed]

63. De Moliner, F.; Bigatti, M.; De Rosas, C.; Banfi, L.; Riva, R.; Basso, A. Synthesis of triazolo-fused benzoxazepines and benzoxazepinones via Paserini reactions followed by 1,3-dipolar cycloadditions. Mol. Divers. 2014, 18, 473-482. [CrossRef] [PubMed]

64. Chatterjee, N.; Sarkar, S.; Pal, R.; Sen, A.K. An approach toward the syntheses of triazolo benzoxazines, triazolo quinoxaline, triazolo benzodiazepines, triazolo benzoxazepines, and triazolo benzothiazines via a simple and convenient protocol using basic alumina as solid support. Tetrahedron Lett. 2014, 55, 2261-2265. [CrossRef]

65. Xing, X.; Wu, J.; Luo, J.; Wei-Min, D. C-N bond-linked conjugates of dibenz[b,f][1,4]oxazepines with 2-oxindole. Synlett 2006, 13, 2099-2103. [CrossRef]

66. Dabholkar, V.V.; Moris, G.D. Synthesis of 4,10-dihydro-5/7substituted-9-oxo-quinolino[2,3-e]-2-amino-1,3,4thiadiazine and Schiff base by microwave irradiation. Indian J. Chem. 2004, 43B, 682-684. [CrossRef]

67. Filippakopoulos, P.; Picaud, S.; Fedorov, O.; Keller, M.; Wrobel, M.; Morgenstern, O.; Bracher, F.; Knapp, S. Benzodiazepines and benzotriazepines as protein interaction inhibitors targeting bromodomains of the BET family. Bioorg. Med. Chem. 2012, 20, 1878-1886. [CrossRef] [PubMed] 
68. Mc Donald, I.M.; Black, J.W.; Buck, I.M.; Dunstone, D.J.; Griffin, E.P.; Harper, E.A.; Hull, R.A.D.; Kalindjian, S.B.; Lilley, E.J.; Linney, I.D.; et al. Optimization of 1,3,4-Benzotriazepine-Based CCK 2 Antagonists to Obtain Potent, Orally Active Inhibitors of Gastrin-Mediated Gastric Acid Secretion. J. Med. Chem. 2007, 50, 3101-3112. [CrossRef] [PubMed]

69. Nagaraja, G.K.; Kumaraswamy, M.N.; Vaidya, V.P.; Mahadevan, K.M. Microwave assisted synthesis of naphtho[2,1-b]furan-1, 3, 4- benzotriazepines: a potent antimicrobial agent. ARKIVOC 2006, 10, 211-219.

70. Dong, C.; Xie, L.; Mou, X.; Zhong, Y.; Su, W. Facile synthesis of 1,3,4-benzotriazepines and 1-arylamide- $1 H$-indazoles via palladium-catalyzed cyclization of aryl isocyanates and aryl hydrazones under microwave irradiation. Org. Biomol. Chem. 2010, 8, 4827-4830. [CrossRef] [PubMed]

71. Gupta, M.; Paul, S.; Gupta, R. Efficient and novel one-pot synthesis of antifungal active 1-substituted-8-aryl-3-alkyl/aryl-4H-pyrazolo[4,5-f][1,2,4]triazolo[4,3-b][1,2,4]triazepines using solid support. Eur. J. Med. Chem. 2011, 46, 631-635. [CrossRef] [PubMed]

72. Gupta, M. Efficient synthesis of antifungal active 9-substituted-3-aryl-5H,13aH-quinolino[3,2-f][1,2,4]triazolo [1,2,4]triazepines in ionic liquids. Bioorg. Med. Chem. Lett. 2011, 21, 4919-4923. [CrossRef] [PubMed]

73. Kidwai, M.; Sapra, P.; Misra, P.; Saxena, R.K.; Singh, M. Microwave assisted solid support synthesis of novel 1,2,4-triazolo[3,4-b]-1,3,4-thiadiazepines as potent antimicrobial agents. Bioorg. Med. Chem. 2001, 9, 217-220. [CrossRef]

74. Raghavendra, M.; Naik, H.S.B.; Naik, T.; Sherigara, B.S. $p$-TsOH Catalysed a Facile One-Pot Synthesis of Some New Substituted 1,2,4 Triazolo[3,4-b]-1,3,4-thiadiazepines under Microwave Irradiation in Solvent Free Conditions. Phosphorus Sulfur Silicon Relat. Elem. 2007, 182, 1823-1831. [CrossRef]

75. Gupta, M.; Paul, S.; Gupta, R. Microwave-assisted one-pot synthesis of antifungal active 1-substituted-3,7-dialkyl/ aryl-4H-pyrazolo[4,5-f][1,3,4]thiadiazepines using solid support. Indian J. Chem. Sect. B 2009, 48B, 460-466.

76. Saleh, T.S.; Abd El-Rahman, N.; Assaker, R.S.A. Microwave promoted a green protocol for solvent free synthesis of 1,5-benzothiazepine and [1,3,4]-thiadiazepine derivatives incorporating thiophene moiety. Green Chem. Lett. Rev. 2012, 5, 315-312. [CrossRef]

77. Pedersen, S.L.; Tofteng, A.P.; Malik, L.; Jensen, J. Microwave heating in solid-phase synthesis. Chem. Soc. Rev. 2012, 41, 1826-1844. [CrossRef] [PubMed]

78. Rizzolo, F.; Sabatino, G.; Chelli, M.; Rovero, P.; Papini, A. A convenient microwave-enhanced solid-phase synthesis of difficult peptide sequences: Case study of gramicidin A and CSF114(Glc). Int. J. Pept. Res. Ther. 2007, 13, 203-208. [CrossRef]

79. Ieronymaki, M.; Androutsou, M.E.; Pantelia, A.; Friligou, I.; Crisp, M.; High, K.; Penkman, K.; Gaton, D.; Tselios, T. Use of 2-chlorotrityl chloride resin for microwave-assisted solid phase peptide synthesis. Pept. Sci. 2015, 104, 506-514. [CrossRef] [PubMed]

80. Bacsa, B.; Horvati, K.; Bosze, S.; Andreae, F.; Kappe, C.O. Solid-phase synthesis of difficult peptides sequences at elevated temperatures: A critical comparison of microwave and conventional heating technologies. J. Org. Chem. 2008, 73, 7532-7542. [CrossRef] [PubMed]

81. Grieco, P.; Cai, M.; Liu, L.; Mayorov, A.; Chandler, K.; Trivedi, D.; Lin, G.; Campiglia, P.; Novellino, E.; Hruby, V.J. Design and Microwave-Assisted Synthesis of Novel Macrocyclic Peptides Active at Melanocortin Receptors: Discovery of Potent and Selective hMC5R Receptor Antagonists. J. Med. Chem. 2008, 51, 2701-2707. [CrossRef] [PubMed]

82. Ibrahim, M.A.; Panda, S.S.; Oliferenko, A.A.; Oliferenko, P.V.; Girgis, A.S.; Elagawany, M.; Küçükbay, Z.; Panda, C.S.; Pillai, G.G.; Samir, A.; et al. Macrocyclic peptidomimetics with antimicrobial activity: Synthesis, bioassay, and molecular modeling studies. Org. Biomol. Chem. 2015, 13, 9492-9503. [CrossRef] [PubMed]

83. Tala, S.R.; Schnell, S.M.; Haskell-Luevano, C. Microwave-assisted solid-phase synthesis of side-chain to side-chain lactam bridge cyclic peptides. Bioorg. Med. Chem. Lett. 2015, 25, 5708-5711. [CrossRef] [PubMed]

84. Chapman, R.N.; Arora, PS. Optimized Synthesis of Hydrogen-Bond Surrogate Helices: Surprising Effects of Microwave Heating on the Activity of Grubbs Catalysts. Org. Lett. 2006, 8, 5825-5828. [CrossRef] [PubMed]

85. Martin-Gago, P.; Ramon, R.; Aragon, E.; Fernandez-Carneado, J.; Martin-Malpartida, P.; Verdaguer, X.; Lopez-Ruiz, P.; Colas, B.; Cortes, M.A.; Ponsati, B.; et al. A tetradecapeptide somatostatin dicarba-analog: Synthesis, structural impact and biological activity. Bioorg. Med. Chem. Lett. 2014, 24, 103-107. [CrossRef] [PubMed]

86. Lépine, R.; Zhu, J. Microwave-Assisted Intramolecular Suzuki-Miyaura Reaction to Macrocycle, a Concise Asymmetric Total Synthesis of Biphenomycin B. Org. Lett. 2005, 7, 2981-2984. [CrossRef] [PubMed] 
87. Auberger, N.; Di Pisa, M.; Larregola, M.; Chassaing, G.; Peroni, E.; Lavielle, S.; Papini, A.-M.; Lequin, O.; Mallet, J.-M. Glaser oxidative coupling on peptides: Stabilization of $\beta$-turn structure via a 1,3-butadiyne constraint. Bioorg. Med. Chem. 2014, 22, 6924-6932. [CrossRef] [PubMed]

88. Kaniraj, P.J.; Maayan, G. A facile strategy for the construction of cyclic peptoids under microwave irradiation through a simple substitution reaction. Org. Lett. 2015, 17, 2110-2113. [CrossRef] [PubMed]

89. Décor, A.; Monse, B.; Martin, M.T.; Chiaroni, A.; Thoret, S.; Guénard, D.; Guéritte, F.; Baudoin, O. Synthesis and biological evaluation of B-ring analogues of (-)-rhazinilam. Bioorg. Med. Chem. 2006, 14, 2314-2332. [CrossRef] [PubMed]

90. Beryozkina, T.; Appukkuttan, P.; Mont, N.; Van der Eycken, E. Microwave-Enhanced Synthesis of New (-)-Steganacin and (-)-Steganone Aza Analogues. Org. Lett. 2006, 8, 487-490. [CrossRef] [PubMed]

91. Appukkuttan, P.; Dehaen, W.; Van der Eycken, E. Microwave-Enhanced synthesis of N-Shifted Buflavine Analogues via a Suzuki-Ring-Closing Metathesis Protocol. Org. Lett. 2005, 7, 2723-2726. [CrossRef] [PubMed]

92. Appukkuttan, P.; Dehaen, W.; van der Eycken, E. Microwave-Assisted Transition-Metal-Catalyzed Synthesis of N-Shifted and Ring-Expanded Buflavine Analogues. Chem Eur. J. 2007, 13, 6452-6460. [CrossRef] [PubMed]

93. Shen, L.; Charles, J.S.; Sun, D. Microwave-assisted synthesis of macrocycles via intramolecular and/or bimolecular Ullmann coupling. Tetrahedron Lett. 2012, 53, 4173-4178. [CrossRef] [PubMed]

94. Pitsinos, E.N.; Vidali, V.P.; Couladouros, E.A. Diaryl Ether Formation in the Synthesis of Natural Products. Eur. J. Org. Chem. 2011, 1207-1222. [CrossRef]

95. Reddy, L.N.V.; Ravinder, K.; Srinivasulu, M.; Goud, V.T.; Reddy, M.S.; Srujankumar, D.; Rao, P.T.; Murty, S.U.; Venkateswarlu, Y. Two New Macrocyclic Diaryl Ether Heptanoids from Boswellia ovalifoliolata. Chem. Pharm. Bull. 2003, 51, 1081-1084. [CrossRef]

96. Lin, J.; Zhang, W.; Jiang, N.; Niu, Z.; Bao, K.; Zhang, L.; Liu, D.; Pan, C.; Yao, X. Total Synthesis of Bulbophylol-B. J. Nat. Prod. 2008, 71, 1938-1941. [CrossRef] [PubMed]

97. Biyiklioglu, Z.; Kantekin, H.; Özil, M. Microwave-assisted synthesis and characterization of novel metal-free and metallophthalocyanines containing four 14-membered tetraaza macrocycles. J. Organomet. Chem. 2007, 692, 2436-2440. [CrossRef]

98. Kantekin, H.; Biyiklioglu, Z. Microwave-assisted synthesis and characterization of novel metal-free and metallophthalocyanines containing four 13-membered dithiadiaza macrocycles. Dyes Pigment. 2008, 77, 98-102. [CrossRef]

99. Biyiklioglu, Z.; Acar, I.; Kantekin, H. Microwave-assisted synthesis and characterization of new soluble metal-free and metallophthalocyanines substituted with four tetrathiamacrocycles through oxy bridges. Inorg. Chem. Commun. 2008, 11, 630-632. [CrossRef]

100. Kantekin, H.; Biyiklioglu, Z.; Çelenk, E. Synthesis and characterization of new metal-free and metallophthalocyanines peripherally fused to four 15-membered tetraoxamonoazamacrocycles by microwave irradiation. Inorg. Chem. Commun. 2008, 11, 633-635. [CrossRef]

101. Çelenk, E.; Kantekin, H. The microwave-assisted synthesis and characterization of novel metal-free and metallophthalocyanines peripherally fused to four 13-membered diazadithia macrocycles. Dyes Pigment. 2009, 80, 93-97. [CrossRef]

102. Kantekin, H.; Dilber, G.; Biyiklioglu, Z.J. A new polymeric phthalocyanine containing 16-membered tetrathia macrocyclic moieties by microwave irradiation: Synthesis and characterization. Organometal. Chem. 2008, 693, 1038-1042. [CrossRef]

103. Kantar, G.K.; Baltas, N.; Mentese, E.; Sasmaz, S. Microwave-assisted synthesis and investigation of xanthine oxidase inhibition of new phthalonitrile and phthalocyanines containing morpholino substituted 1,2,4-triazole-3-one. J. Organomet. Chem. 2015, 787, 8-13. [CrossRef]

104. Srimurugan, S.; Viswanathan, B.; Varadarajan, T.K.; Varghese, B. Microwave assisted cyclocondensation of dialdehydes with chiral diamines forming calixsalen type macrocycles. Tetrahedron Lett. 2005, 46, 3151-3155. [CrossRef]

105. Srimurugan, S.; Suresh, P.; Pati, H.N. Microwave assisted synthesis of 72-membered chiral hexanuclear macrocyclic Schiff base. J. Incl. Phenom. Macrocycl. Chem. 2007, 59, 383-388. [CrossRef]

106. Yan, C.; Xhen, W.; Chen, J.; Jiang, T.; Yao, Y. Microwave irradiation assisted synthesis, alkylation reaction, and configuration analysis of aryl pyrogallo[4]arenes. Tetrahedron 2007, 63, 9614-9620. [CrossRef] 
107. Sardjono, R.E.; Kadarohman, A.; Mardhiyah, A. Green synthesis of some calix[4]resorcinarene under microwave irradiation. Procedia Chem. 2012, 4, 224-231. [CrossRef]

108. Nayak, S.K.; Choudhary, M.K. Microwave assisted synthesis of 1,3-dialkyl ethers of calix[4]arenes: Application to the synthesis of cesium selective calix[4]crown-6 ionophores. Tetrehedron Lett. 2012, 53, 141-144. [CrossRef]

109. Burilov, V.A.; Nugmanov, R.I.; Ibragimova, R.R.; Solovieva, S.E.; Antipin, I.S.; Konovalov, A.I. Microwave-assisted alkylation of $p$-tert-butylcalix[4]arene lower rim: The effect of alkyl halides. Mendeleev Commun. 2013, 23, 113-115. [CrossRef]

110. Galan, H.; de Mendoza, J.; Prados, P. Microwave-assisted synthesis of a nitro- $m$-xylylenedioxycalix[6]arene building block functionalized at the upper rim. Eur. J. Org. Chem. 2010, 36, 7005-7011. [CrossRef]

111. Garska, B.; Tabatabai, M.; Ritter, H. Calix[4]arene-click-cyclodextrin and supramolecular structures with watersoluble NIPAAM-copolymers bearing adamantly units: "Rings on ring on chain". Beilstein J. Org. Chem. 2010, 6, 784-788. [CrossRef] [PubMed]

(C) 2016 by the authors; licensee MDPI, Basel, Switzerland. This article is an open access article distributed under the terms and conditions of the Creative Commons Attribution (CC-BY) license (http://creativecommons.org/licenses/by/4.0/). 